\title{
توظيف البحث العلمي في تطوير تعليم وتعلم الرياضيات في الملكة العربية السعودية
}

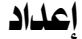

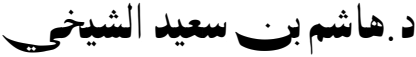 \\ أستاذ مناهج وطرق تدريس الرياضيات المسـاعد \\ كلية التربية - جامعة الملك فيصل بـالإحساء
}

مجلة بحوث التربية النوعية - جامعة المنصورة

عدد (rr) - يوليو r.ll 
إعداد

د ـ ماشمبرنعبد الشيخجيـ

|الاستخفاص:

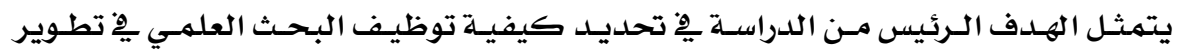

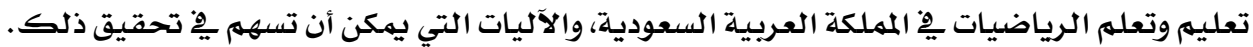

ولتحقيق الهدف السابق سعت الدراسة للإجابة عن الأسئلة التالية:

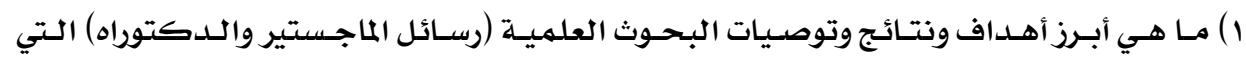

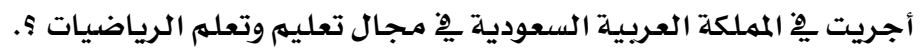

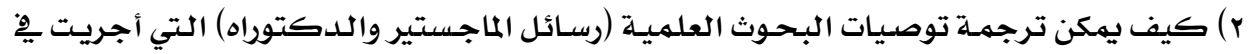

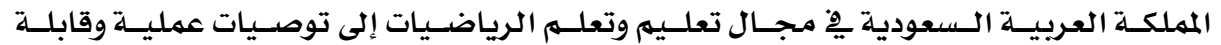

للتطبيق؟

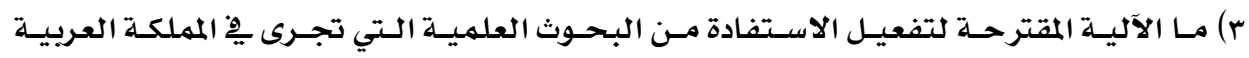

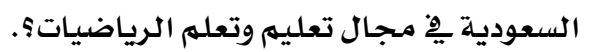

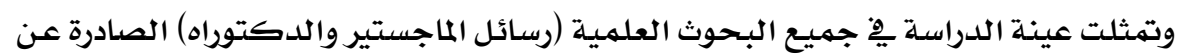

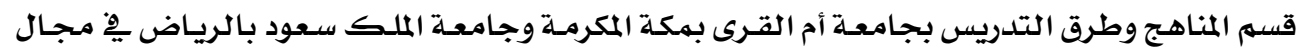

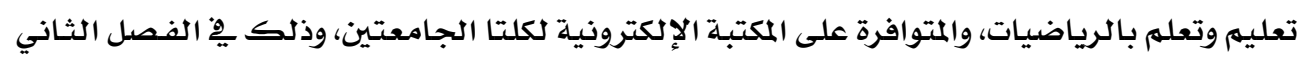

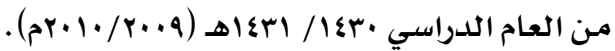

واستخدم الباحث ِِّ هذه الدراسة المنهج المسحي والمنهج الوصفي التحليلي، حيث قام بمستح

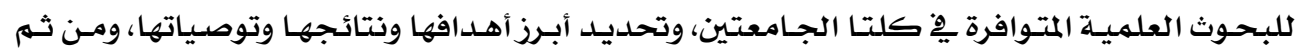

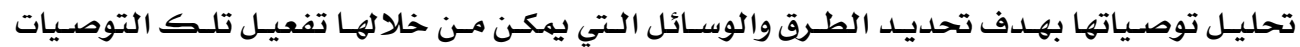

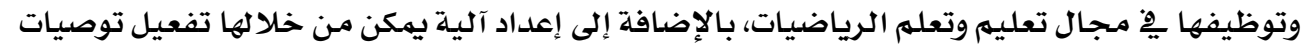

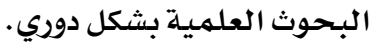

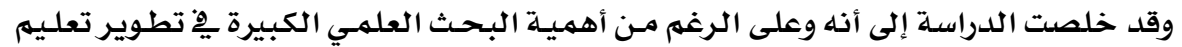

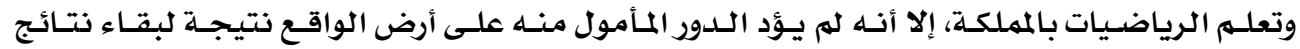

* أستاذ مناهج وطرق تدريس الرياضيات المساعد - كلية التربية - جامعة الملك فيصل بالإحساء 
وتوصيات تلك البحوث حبيسة الأدراج ودون توظيف حقيقي لنتائجها وتوصياتها، بالإضافة إلى الهدر الناتج عن إجراء بحوث علمية يصعب توظيف توصياتها أو الاستفادة من نتائجها.

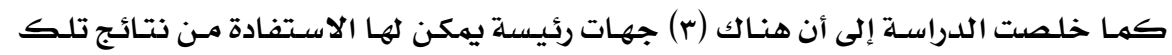

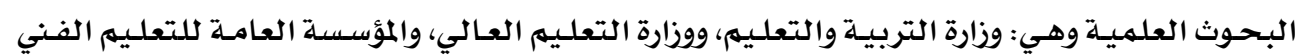
والتدريب المهني.

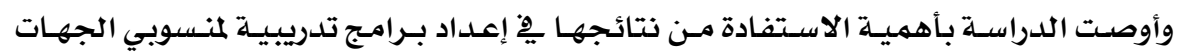

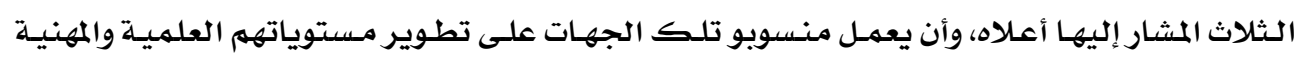
بشكل مستمـر.

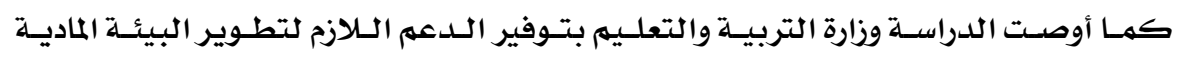

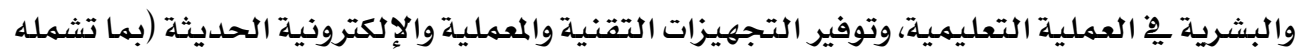

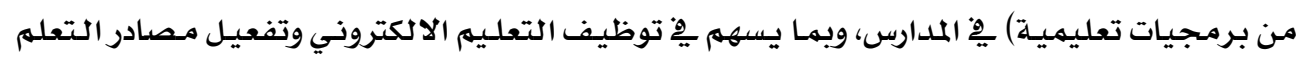
وتوظيف التقنيات الحديثة يِ العملية التعليمية. كما أوصت الدراسـة المؤسسـات التعليمية بوزارة التعليم العالي بتطوير برامـج إعداد المعلمـين بكليات التربية من خلال إدخال مقررات جديدة تتناول عدة موضوعات توصلت إليها الدراسـة الحالية.

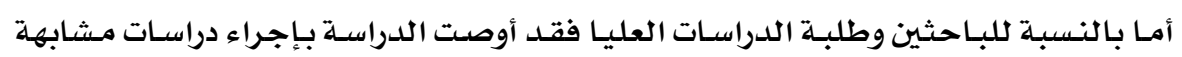

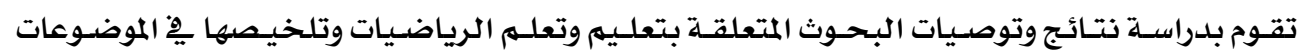

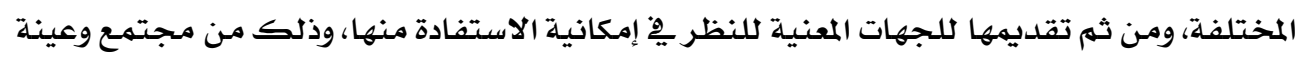
أخرى تثتتمل على دراسات محلية وإقليمية وعالميلة.

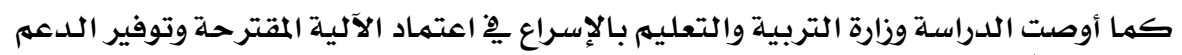

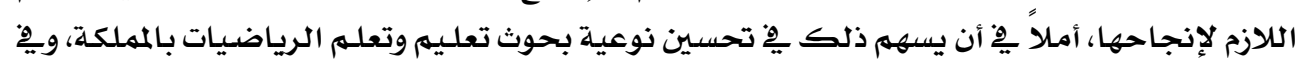
حُسن الاستفادة منها. 


\section{$\overline{\overline{ }}$

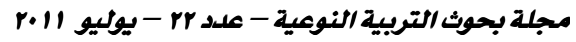 \\ Research summary \\ THE SCIENTIFIC RESEARCH EMPLOYMENT IN DEVELOPING TEACHING AND LEARNING MATHEMATICS IN SAUDI ARABIA}

\section{Dr. Hashem Saeed Al-Shaikhy}

The main objective of the study is determining how to employ the scientific research in developing teaching and learning mathematics processes in Saudi Arabia. The study also shades the required tools to accomplish the proposed goal.

To achieve that objective, the study responds to the following questions:

1. What are the chief objectives, results and the recommendations of the master and doctorate scientific researches conducted in the fields of teaching and learning mathematics in Saudi Arabia?

2. How can the recommendations of the master and doctorate scientific researches conducted in the fields of teaching and learning mathematics in Saudi Arabia be utilized as practical and applicable ideas?

3. What is the proposed technique to benefit of the scientific researches conducted in the fields of teaching and learning mathematics in Saudi Arabia?

The study samples of the research are all available conducted teaching and learning mathematics master and doctorate scientific researches issued by electronic library of the curriculum and methodology departments of Am Elkora and King Saud universities. The used materials are pertaining to the second semester of the years 2010/2011.

The researcher has used both the survey and descriptive as well as analytical techniques.

The study has concluded that in spite of the significance of the scientific research in developing the processes of teaching and learning mathematics in the Kingdom, in reality the scientific research has not accomplished the proposed objectives yet. The researcher has indicated that the reason is ignoring the conclusions and recommendations and the failure to effectively as well as truly employ them. 
The study has also concluded that there are three main agencies that can make use of the results of those scientific researches. Those areas are: Ministry of Education, Ministry of High Education, and the General Establishment of Technical and Vocational Training.

The study has pointed out the great importance of utilizing its results in developing training programs for the staff of the above mentioned three agencies.

In addition, the study has suggested that the Ministry of Education ensures the necessary support and requirements to improve the human and material resources concerning the educational process. This operation should assist in utilizing the electronic learning, benefiting of all sources of learning, as well as taking the advantage of the modern technology in the learning process.

The study has recommended Saudi universities develop instructors' training programs that include new subjects. The designed subjects should deal with a number of topics concluded by the study at hand.

With regard to the researchers, the study has mentioned the need of developing similar researches that study and analyze the results and conclusions of learning and teaching mathematics processes. The study has indicated that the findings should then be submitted to the related agencies to consider the most effective ways of utilizing them. The studies are recommended to be compared with others including local, regional and universal ones.

The study has recommended that the Ministry of Education facilitates adopting the proposed technique and provides the necessary support. Finally, the researcher hopes the study helps improving the quality of the studies concerning teaching and learning mathematics in Saudi Arabia and the exemplary use of them. 


\section{توظيف البحث العلمي في تطوير تعليم وتعلم الرياضيات}

\section{في المهلكة العربية السهودية}

إعداد

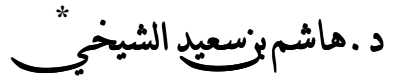

هشكلة الدراسة:

هقدمة

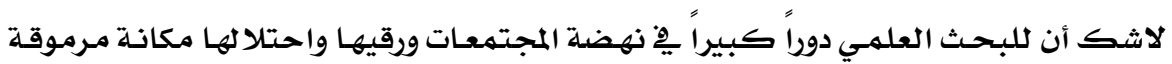

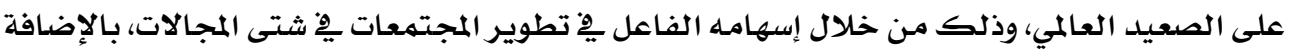

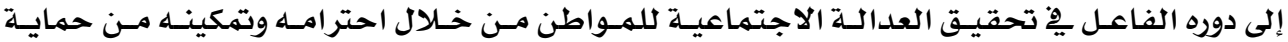

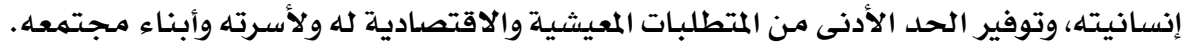

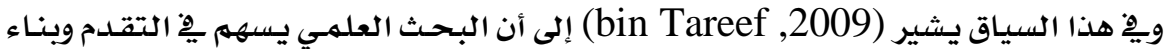

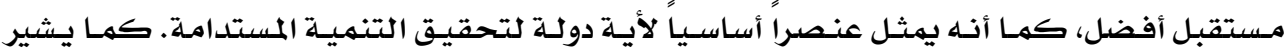

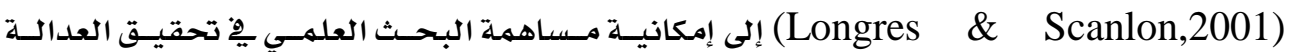
الاجتماعية.

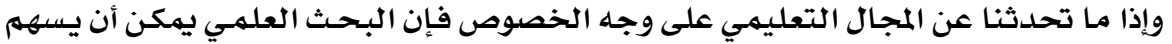

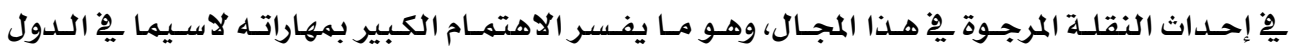

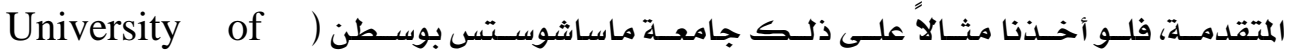
(Massachusetts Boston

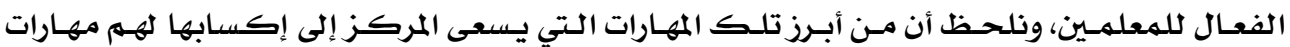

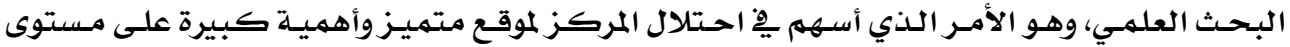

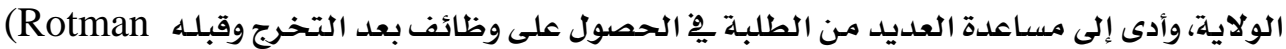
.\& Messelaar, 2005a)

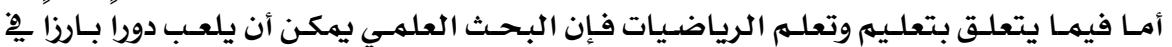

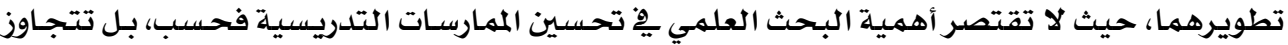

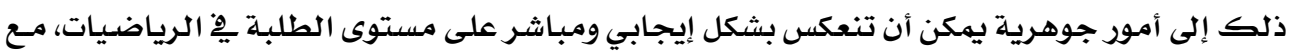

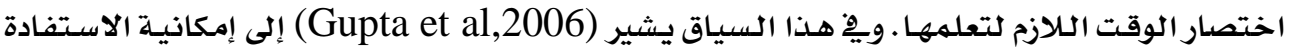

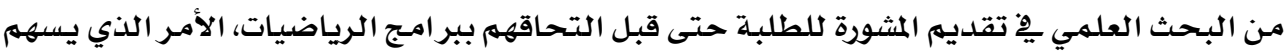




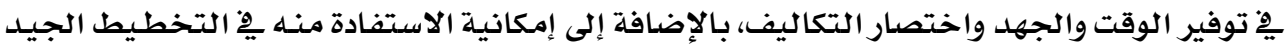

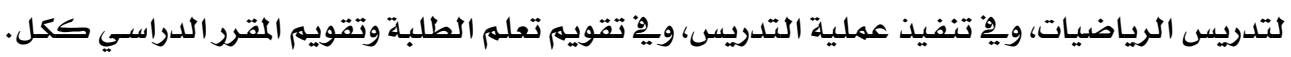

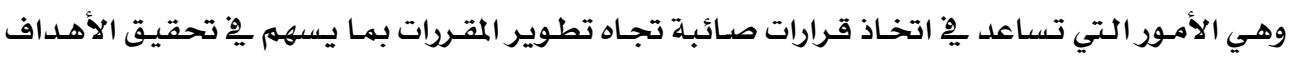
المرجوة بكفاءة وتميز.

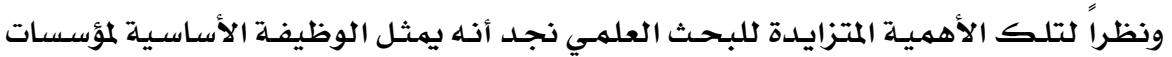

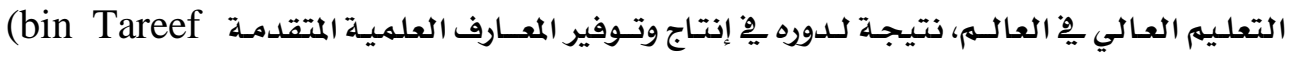
(2009, . ولعل تلك الأهمية للبحث العلمي تفسر حجم الاهتمام به وبإكسـاب مهاراته الطلبـة أثنـاء

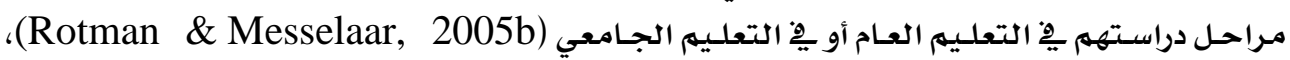
(Brown \& ، (Zubova et al,2009)،(Lamanauskas \&Augiene,2009) .Yürekli,2007)

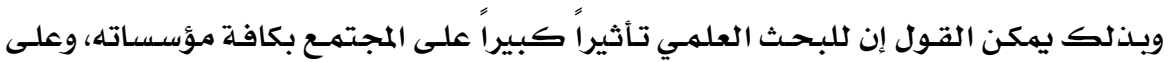

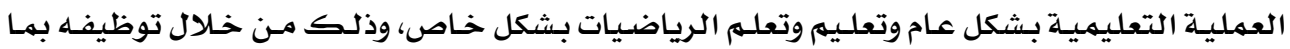

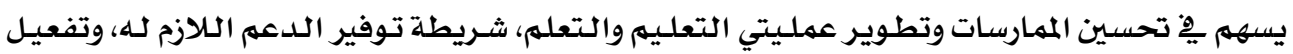

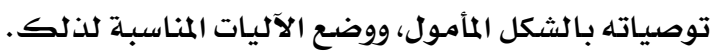
هشكلة الدراسة وأسئلتها:

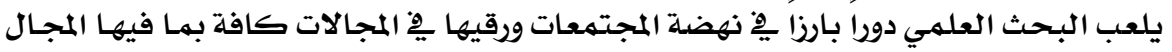

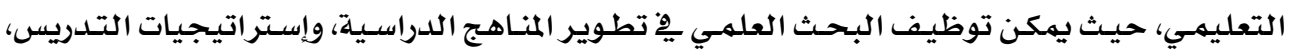

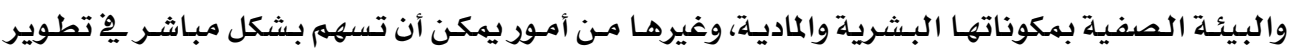

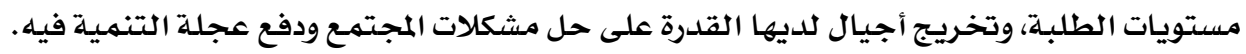

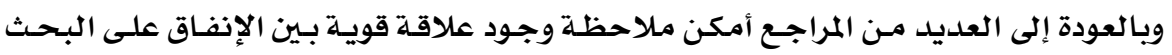

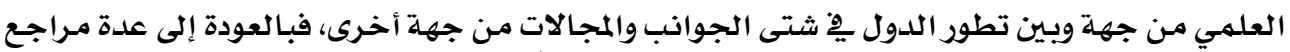

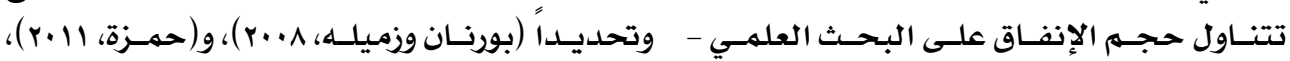

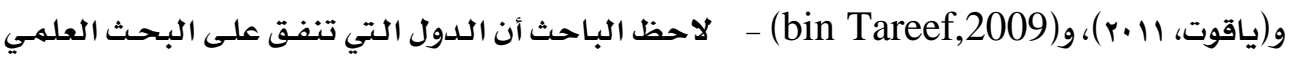

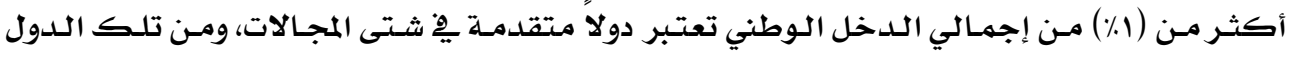

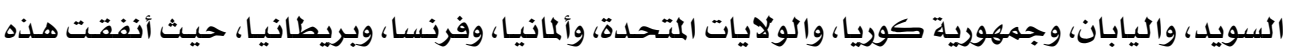

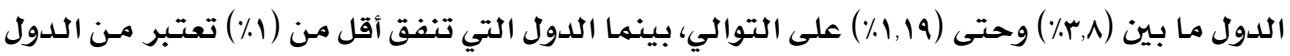

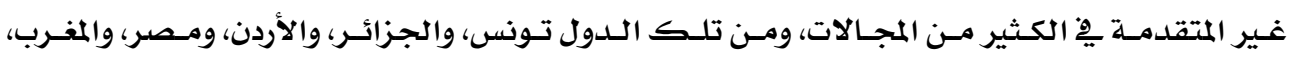

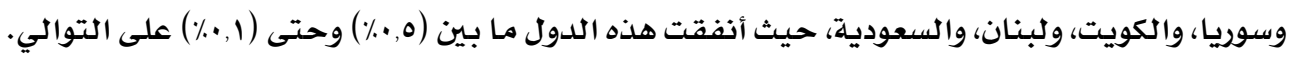

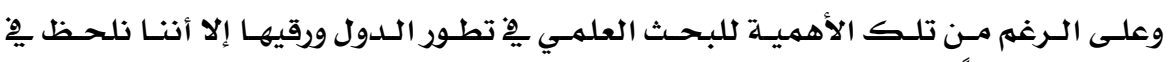

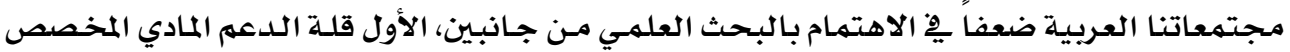

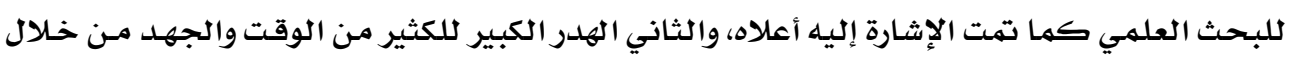

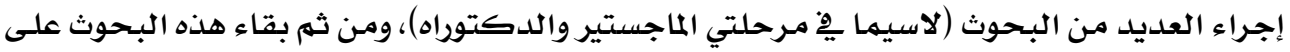


رفوف المكتبات دون استفادة حقيقية من نتائجها وتوصياتها، بـل يتجـاوز الأمـر ذلك إلى البحـوث التي ألتي

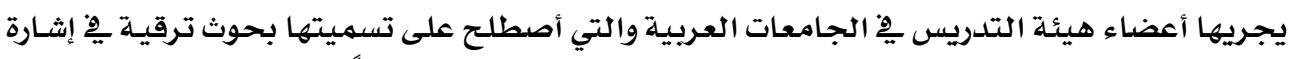

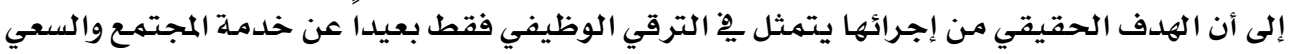

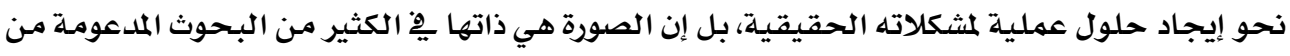

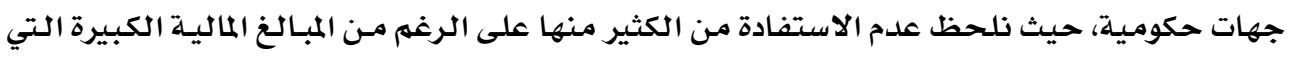

$$
\text { صرفت عليها. }
$$

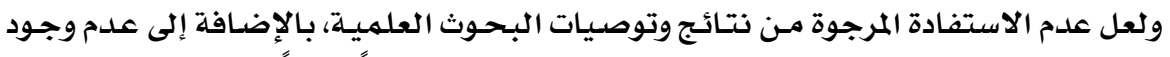

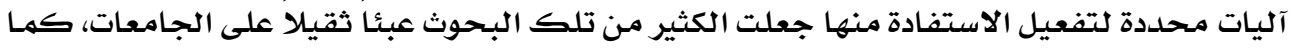

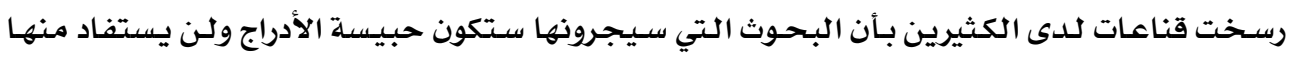

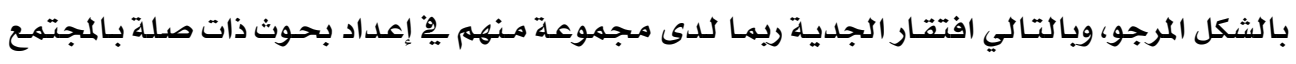
ومشكلاته.

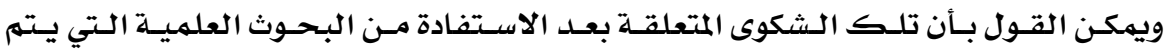

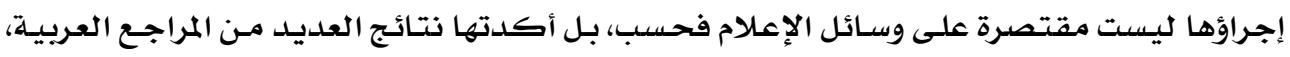

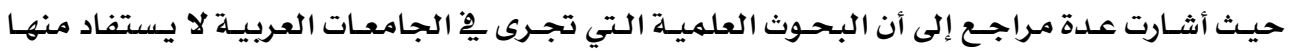

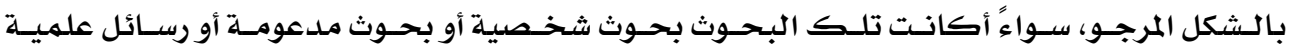

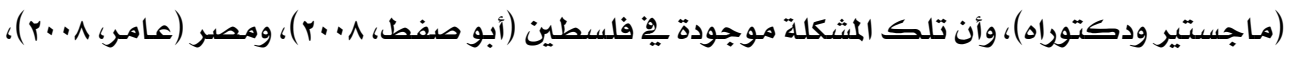

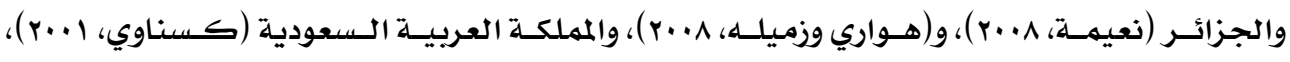

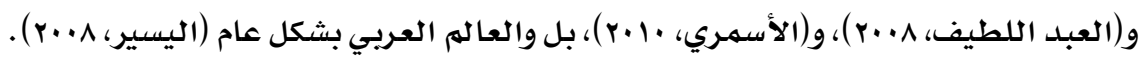

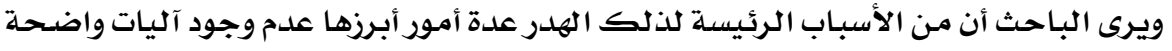

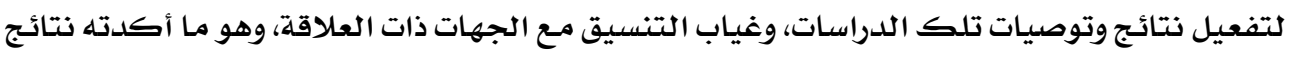

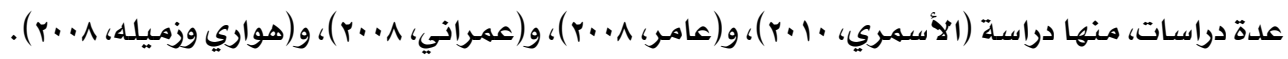
وتزداد أهمية الاستفادة من البحوث العلميلة ووضع الآليـات المناسبة لتفعيل الاستفادة منهـا

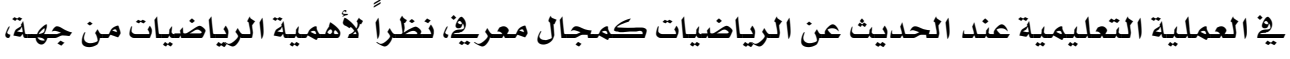

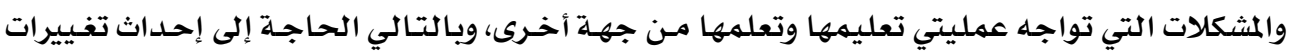

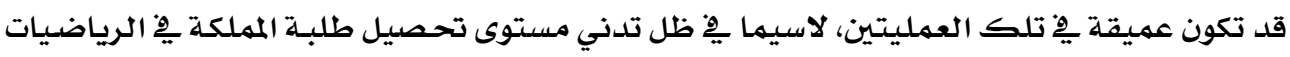

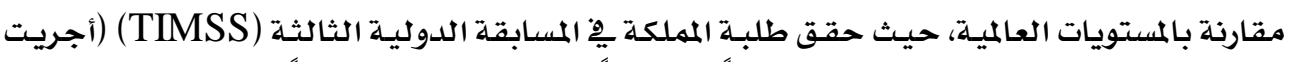

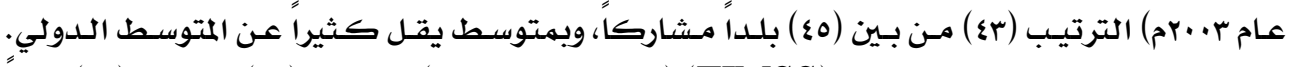

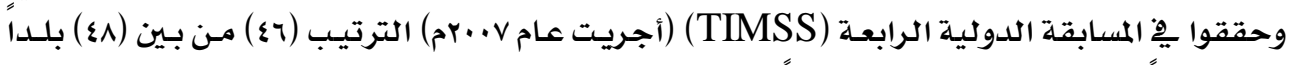

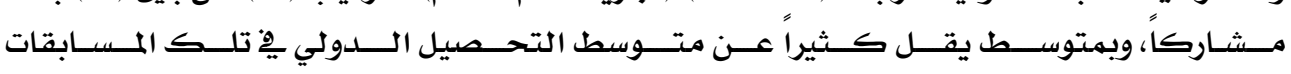
.(TIMSS,2009)، (TIMSS,2005)

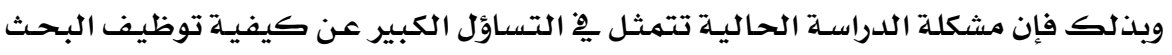

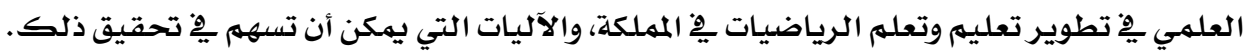




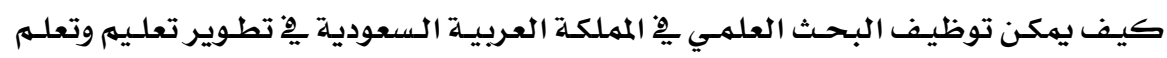

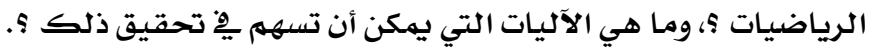

ويتفرع من هذا السؤال الأسئلة التالية:

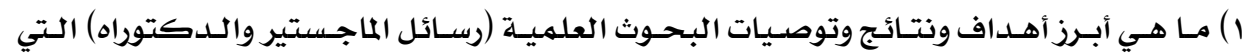

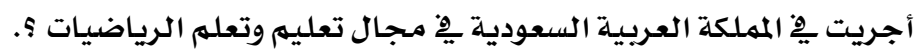

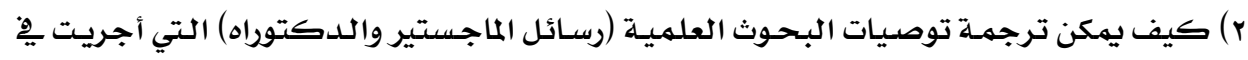

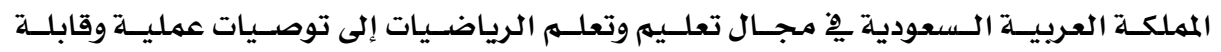
للتطبيق؟

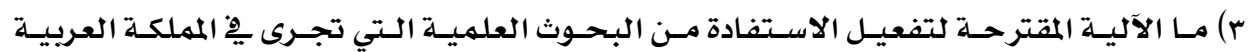

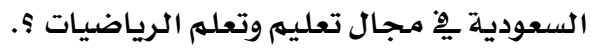

أهداف الدراسة:

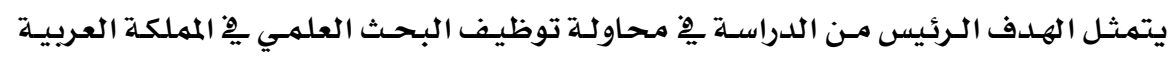
السعودية يِّ تطوير تعليم وتعلهم الرياضيات ؟. وتتمثثل أهداف الدراسـة تحديداً فيما يلي:

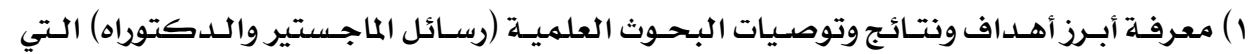

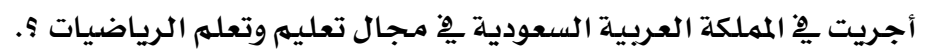

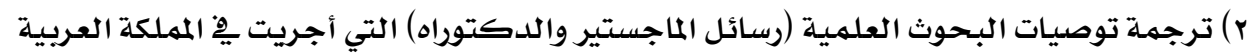

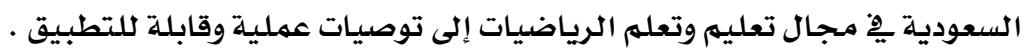

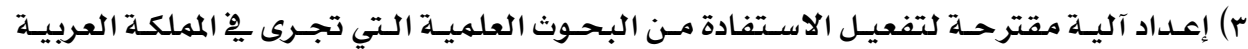

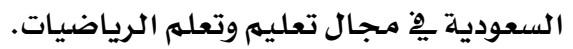

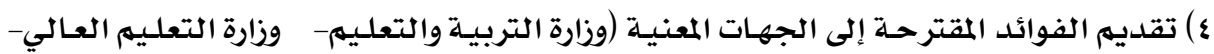

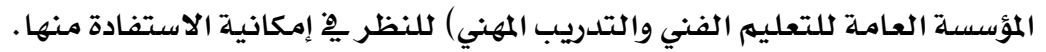

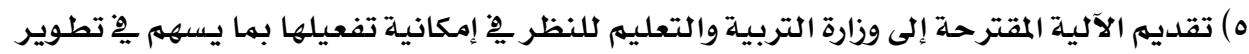
تعليم وتعله الرياضيات بالمملكة.

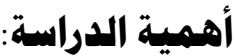

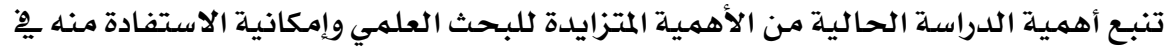

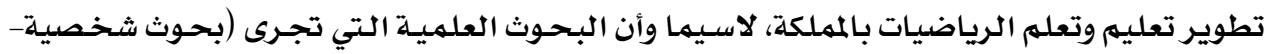

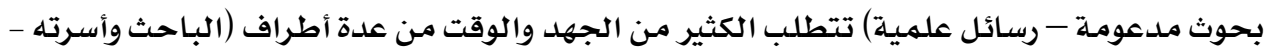

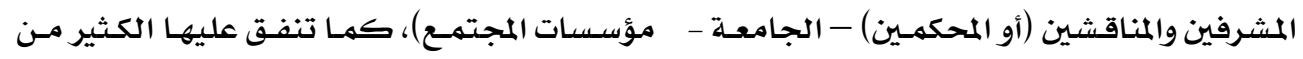




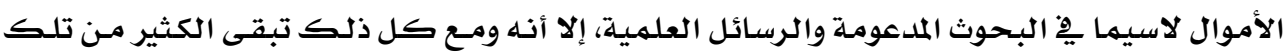
البحوث دون استفادة حقيقية منها.

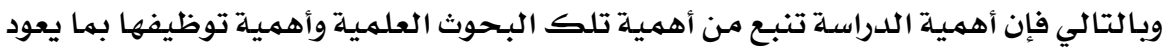

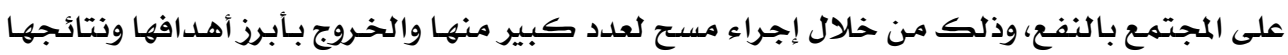

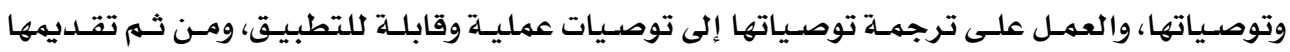

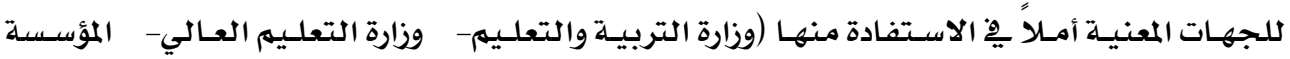

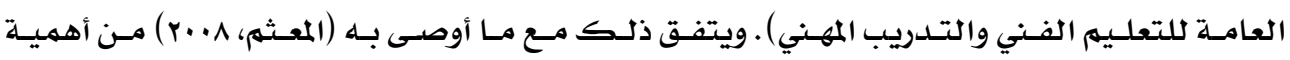

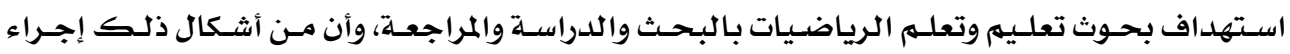

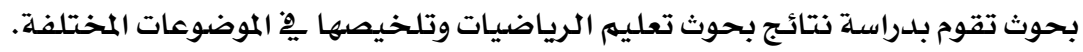

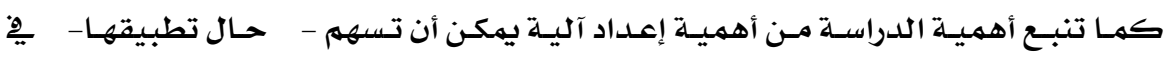

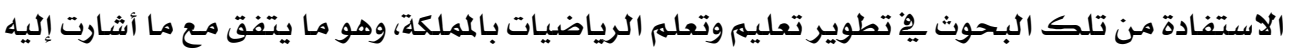

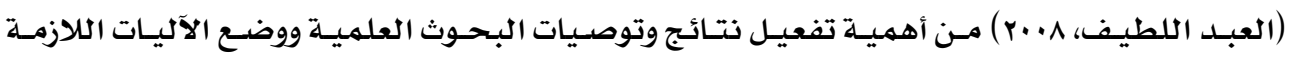

\section{هصطاحات الدراسة:}

\section{• البحث العلمي:}

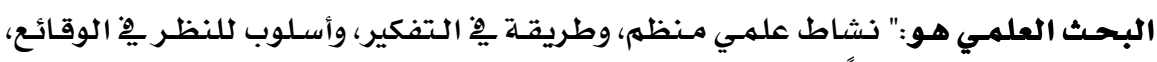

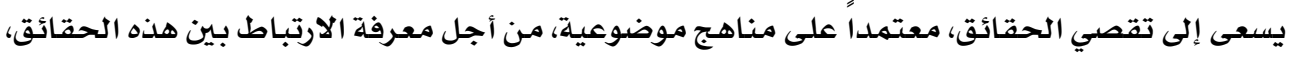

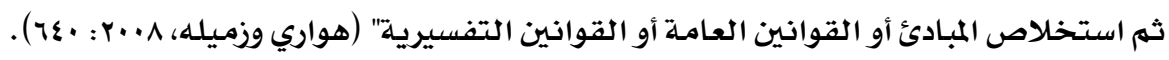
التعريف الإجرائي للباحث:

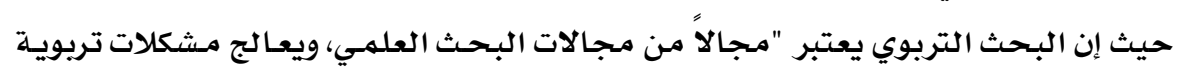

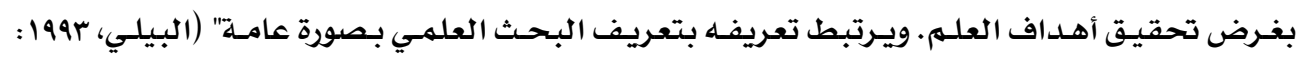

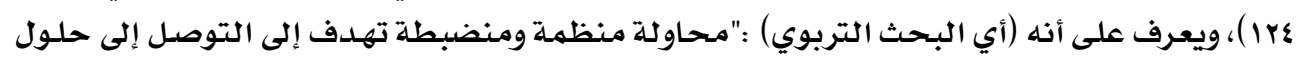

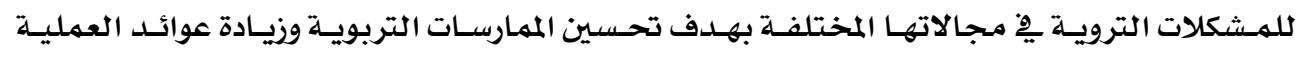

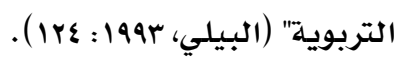

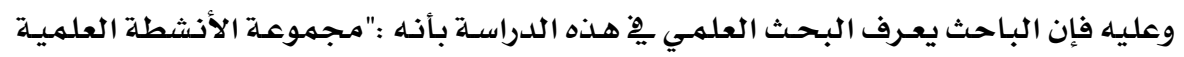

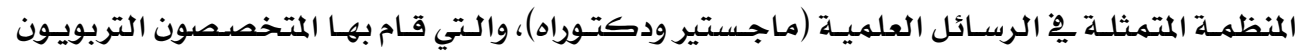

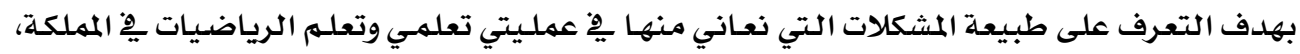

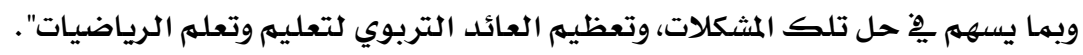

\section{حدود الدراسة:}

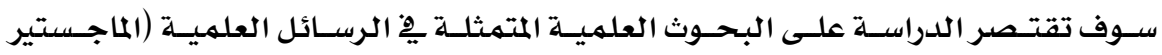

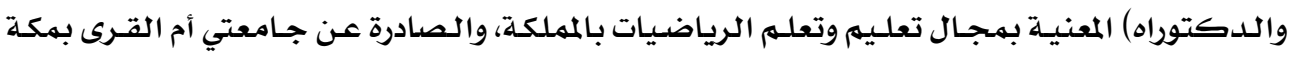




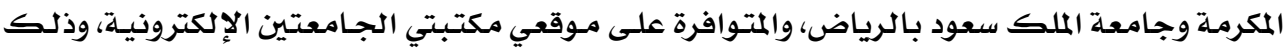

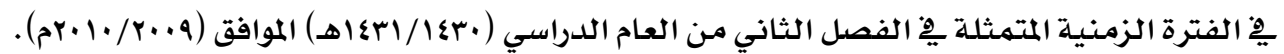

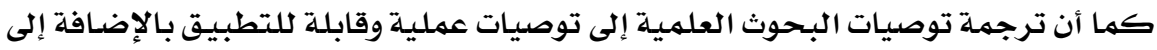

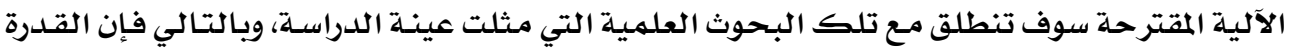

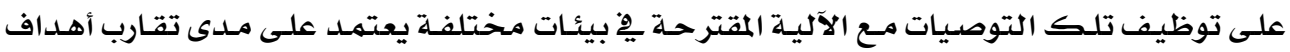

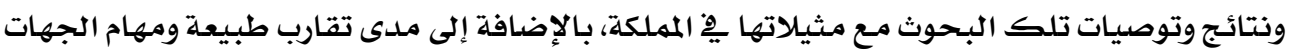

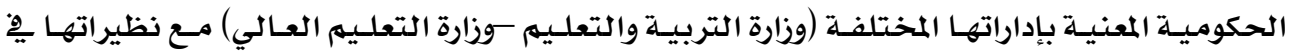

\section{الإطار النظري والدراسات السابقة:}

سوف تتمى الإثـارة ِِّ هذا الجزء إلى ما يلي:

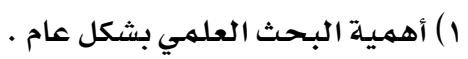

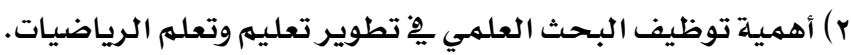

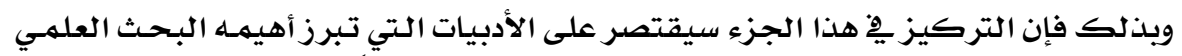

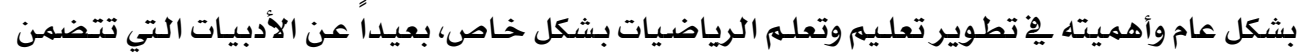

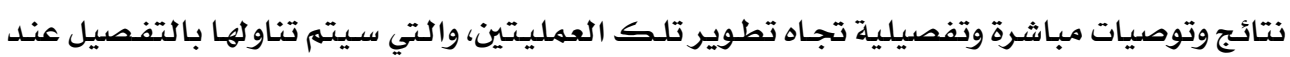

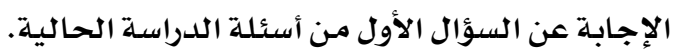

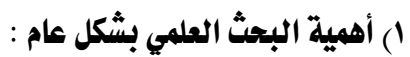

هناك العديد من الدراسات التي أشـارت إلى أهمية البحث العلمي يِّ تطور المجتمعات ورقيها

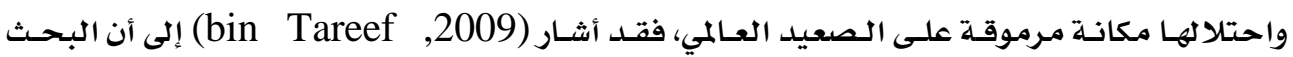

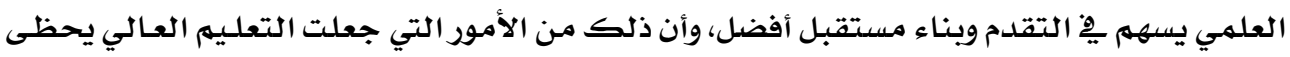

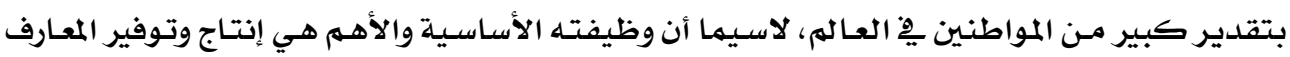
العلمية المتقدمة.

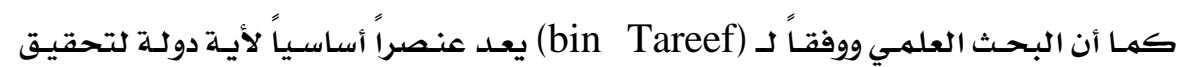

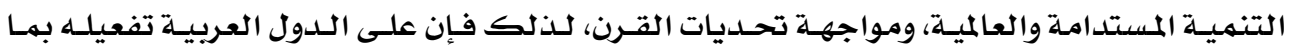

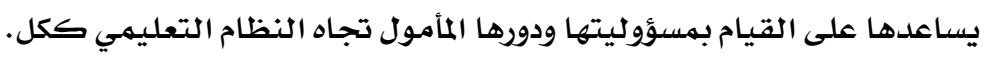

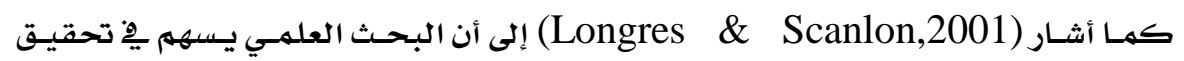

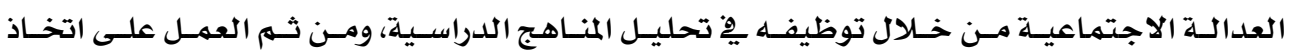

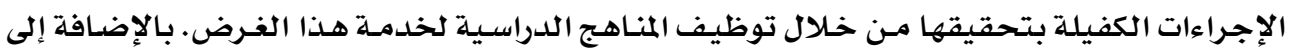

أهميته ِِِ خلق وتوليد المعرفة.

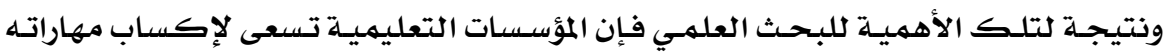

للطلبة، فقد أشار (Lamanauskas \&Augiene,2009) إلى أهمية البحث العلمي وضـرورة العهـل 


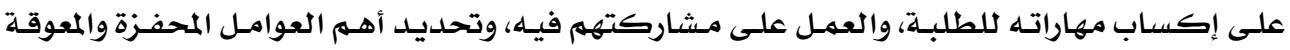

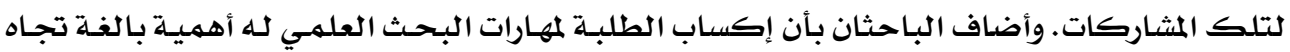

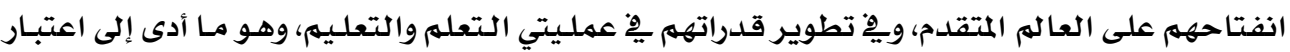

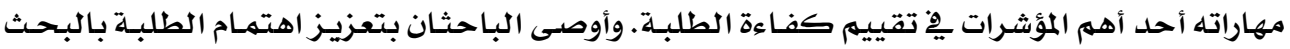

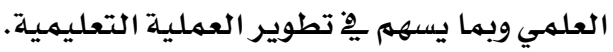

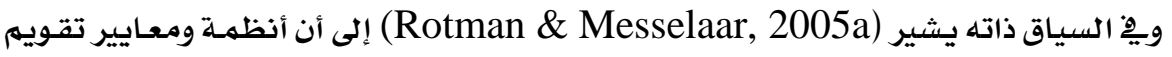

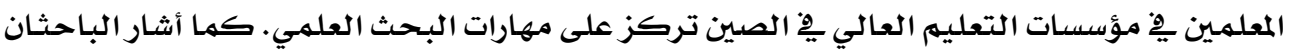

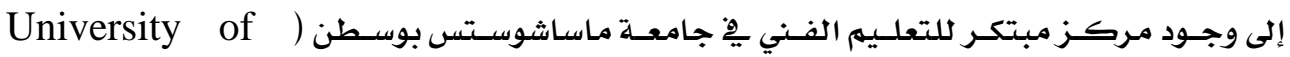
(Massachusetts Boston

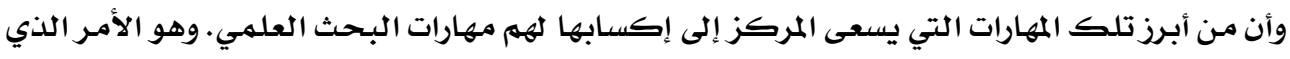

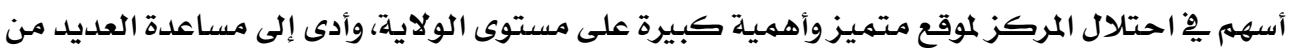

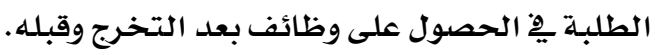

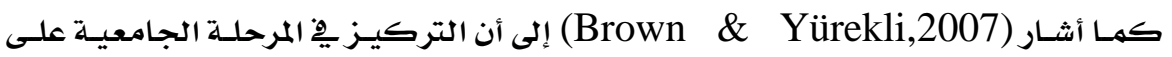

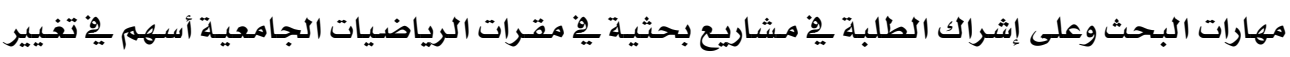

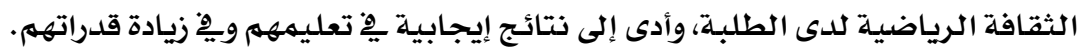

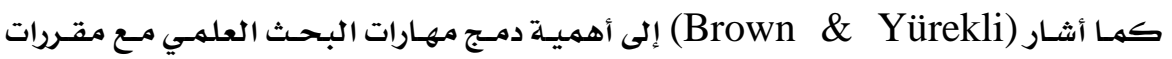

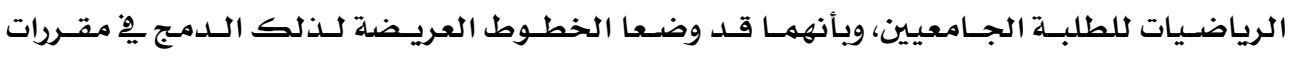

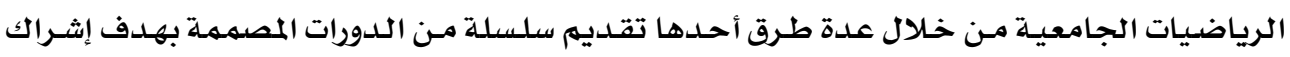

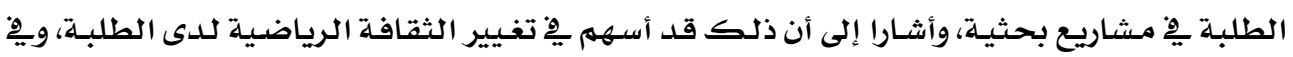
زيادة معارفهم ومهاراتهم التعليميلة والبحثية.

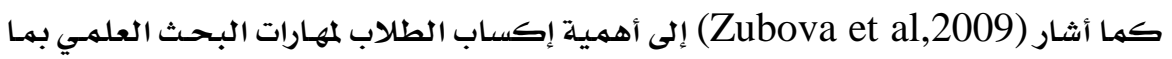

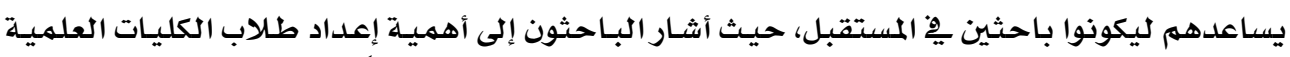

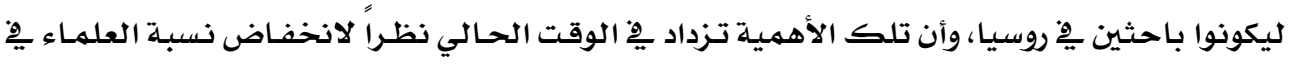

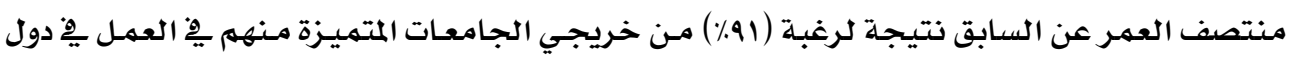

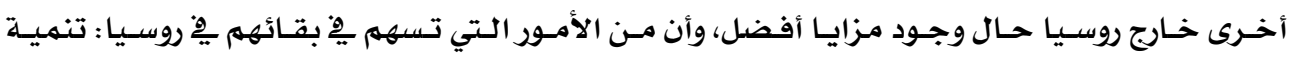

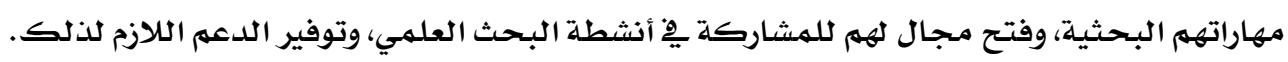

\section{r أهمية توظيف البحث العلمي في تطوير تعليم وتعلم الرياضيات:}

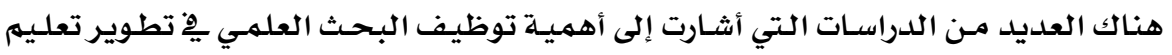

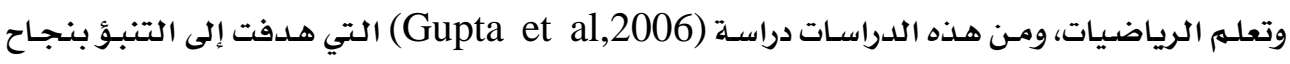

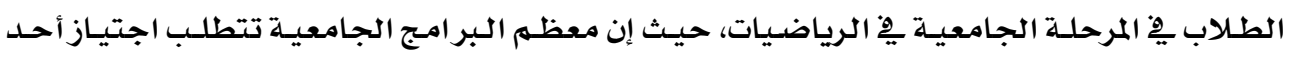

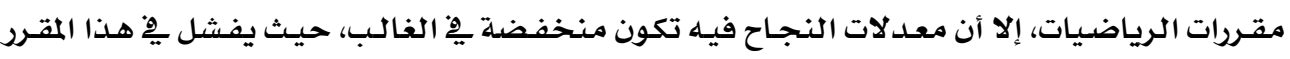




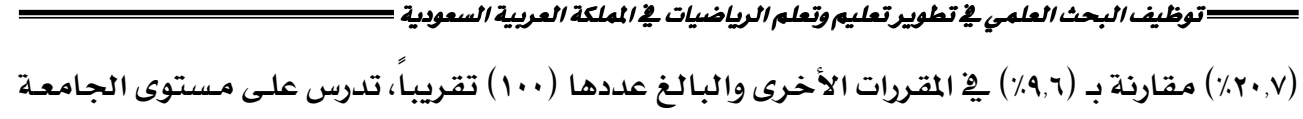
ككل.

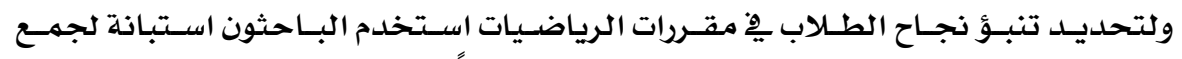

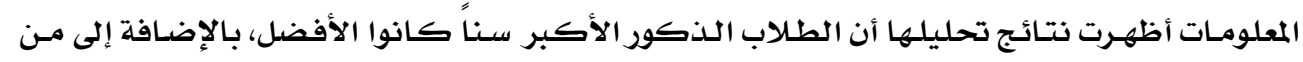

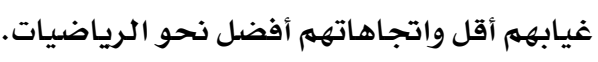

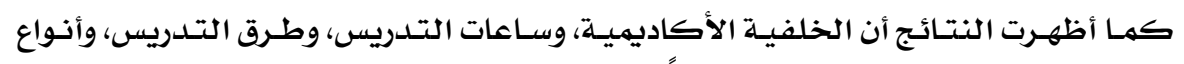

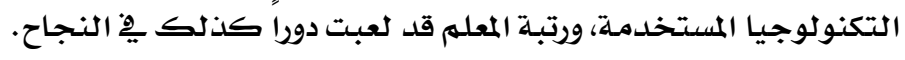

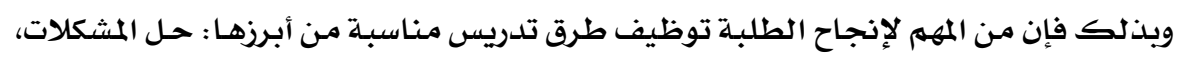

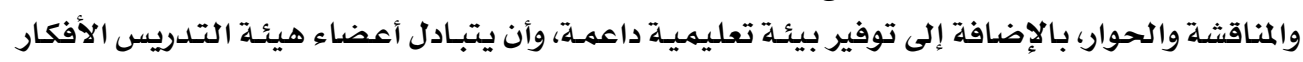

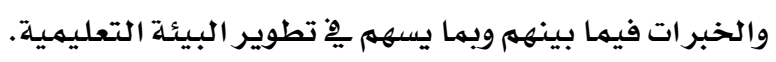

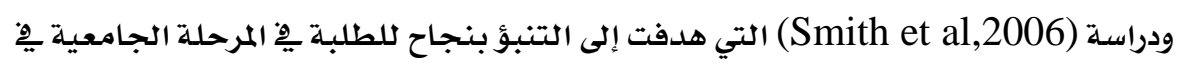

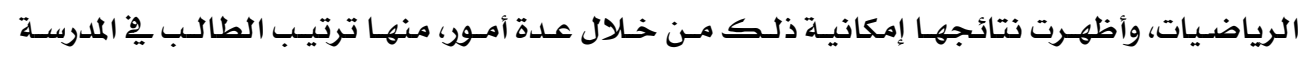

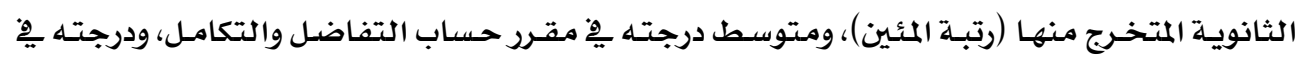

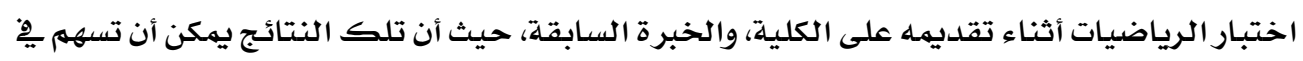

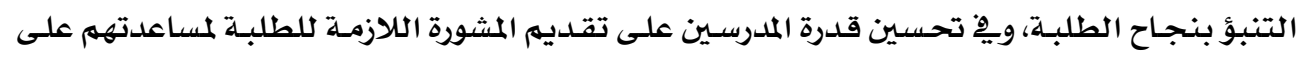
النجاح.

ودراســة (Weinstein \& Laverghetta,2009) الستي هـدفت إلى معرفـة أثـر الخـبرة

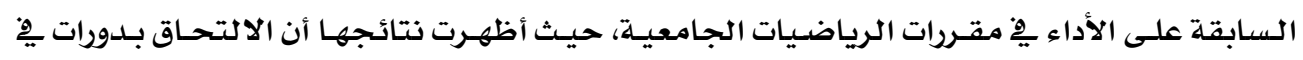

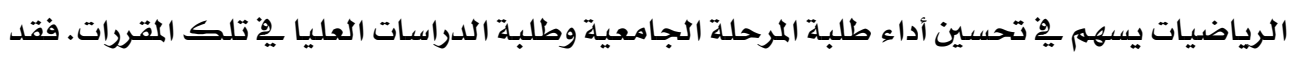

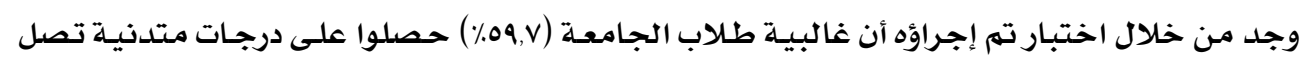

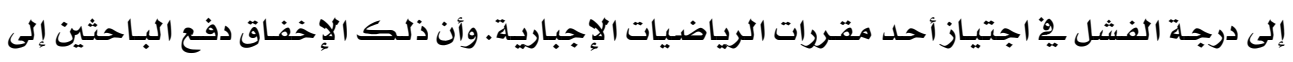

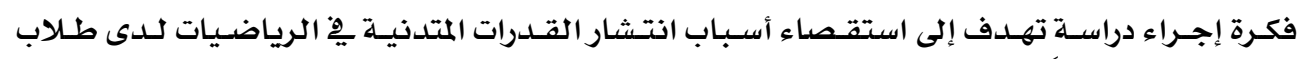

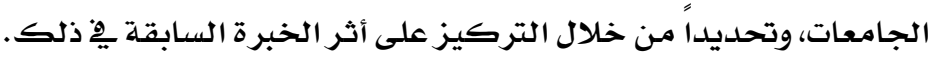

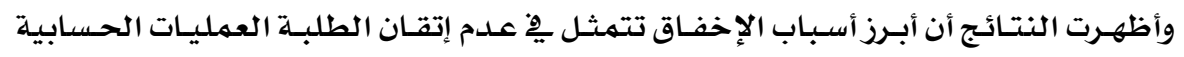

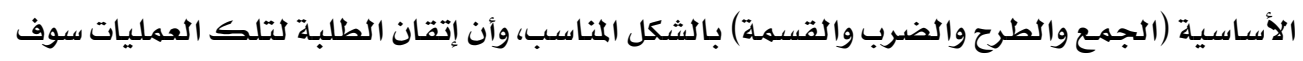

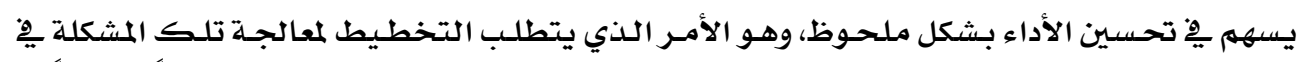

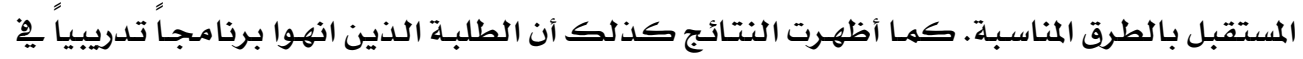

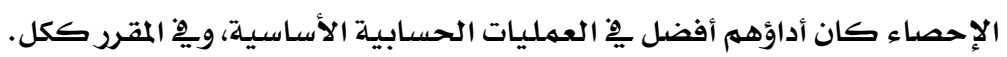

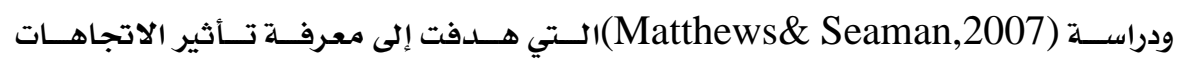

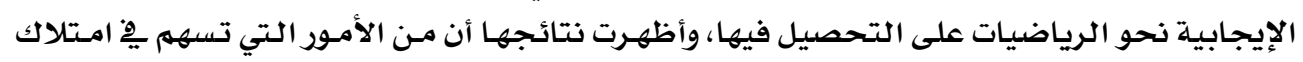

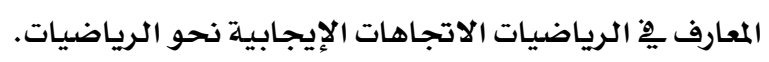


أما فيما يتعلق بالتعليم العام فقد أشارت (Gupta et al,2006) إلى أنه لوحظ بِ المسابقة

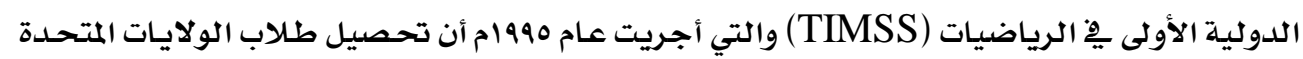

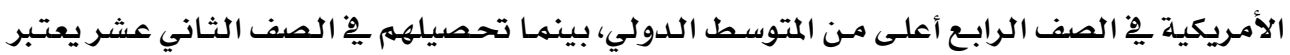
أقل بكثير من متوسط الكثير من الدول.

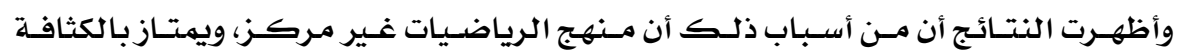

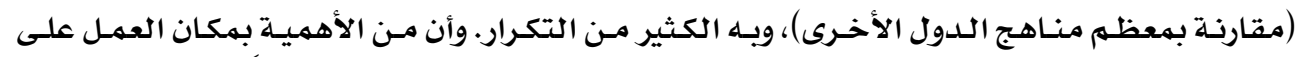

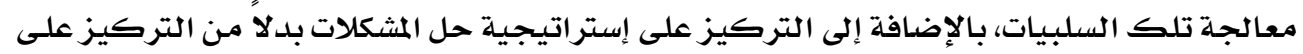
الحفظ.

\section{تعليق على الإطار النظري والدراسات السابقة:}

من خلال الاستعراض السابق يمكن الإثارة إلى النقاط التالية:

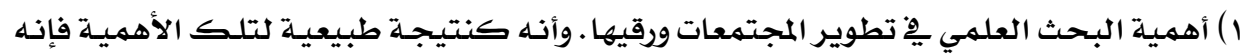

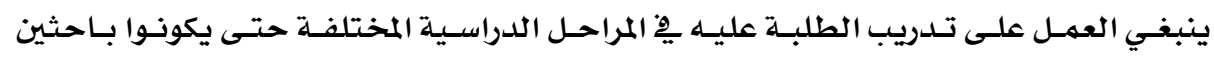

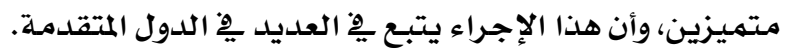

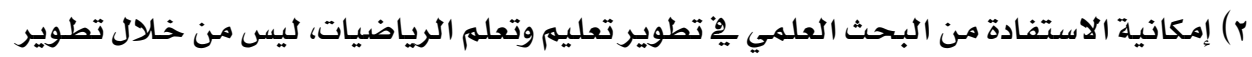

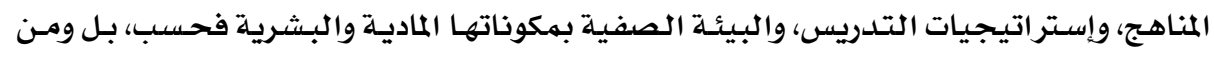

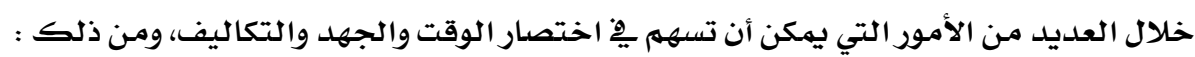

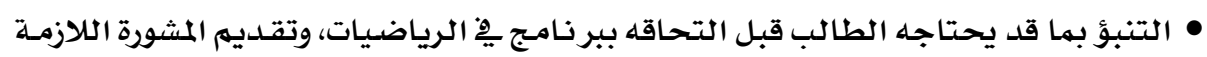

لذلك.

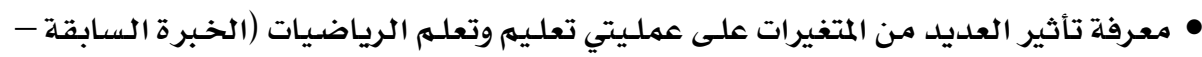

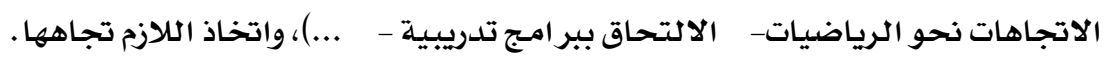

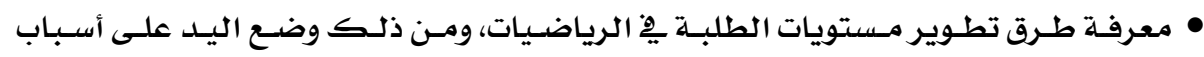

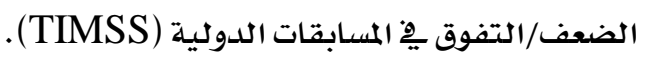

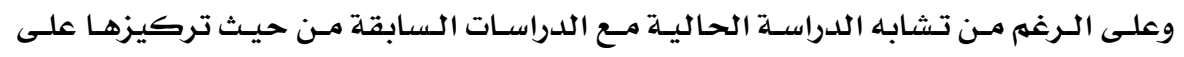

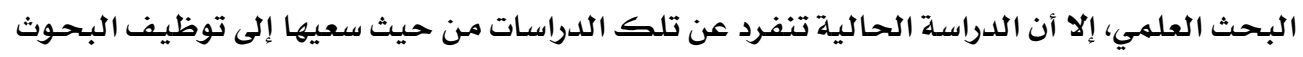

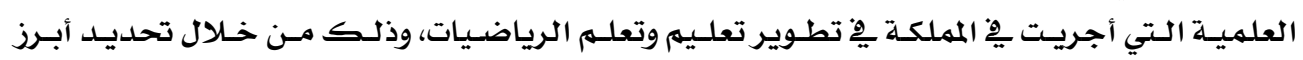

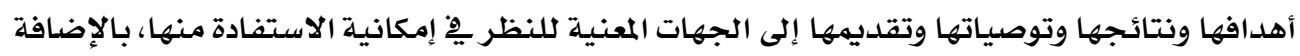

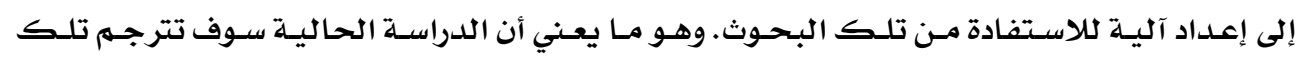

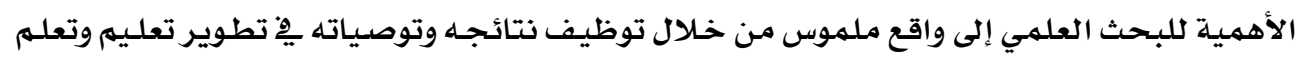
الرياضيات بالمملكة. 


\section{خطوات وإجراءات الدراسة:}

\section{مجتمع الدراسة وعينتها:}

تمثل مجتهـع الدراسـة ِِّ جميـع البحـوث العلميـة ( رسـائل الماجستير والدكتوراه) الصـادرة

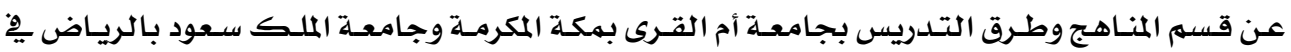

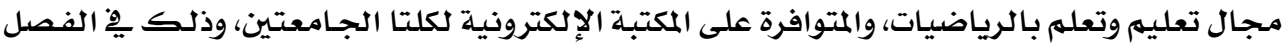

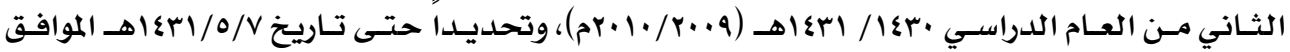
.

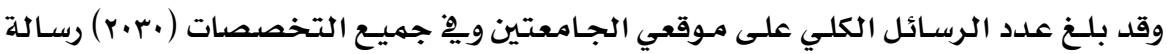

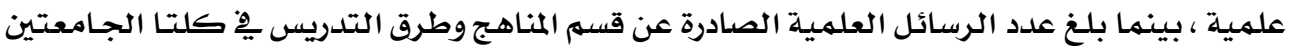

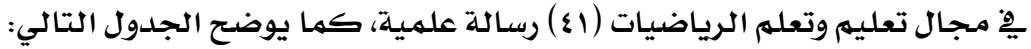
جدول رقم (1): (1)

عدد رسائل الماجستير والدكتوراه الصادرة عن جامعة أم القرى وجامعة الملك سعود والمتوافرة على المكتبة الإلكترونيـة للجامعتين

\begin{tabular}{|c|c|c|c|c|c|}
\hline ملاحظات & الكلي & جامعة الملك & جامعة أم & 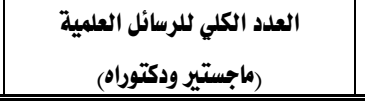 & 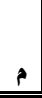 \\
\hline & $r \cdot r \cdot$ & AEr & $11 \mathrm{AA}$ & |الصادرة عن الجامعة ككل & 1 \\
\hline 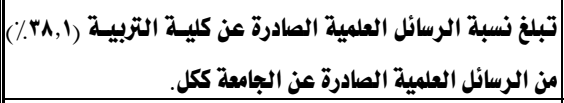 & rv\& & roq & 010 & |الصادرة عن كلية التربية & $r$ \\
\hline |تبلغ نسبة الرسائل العلميـة الـصادرة عـن قـسم المنـاهج وطـرق & rol & 97 & 110 & 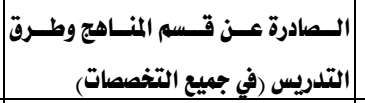 & $r$ \\
\hline 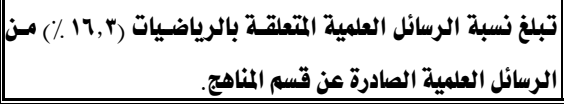 & $\$ 1$ & $\wedge$ & r & 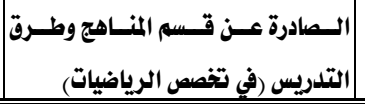 & $\varepsilon$ \\
\hline
\end{tabular}

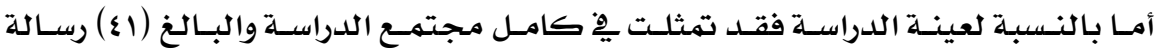
علمية، كما يوضحها الجدول التالي:

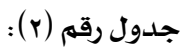

عدد رسـائل الماجستير والدكتوراه الصادرة عن جامعة أم القرى وجامعـة الملك سعود والمتوافرة على المكتبـة الإلكترونية للجامعتين وفق عدة متغيرات

\begin{tabular}{|c|c|c|c|c|c|c|c|c|c|c|}
\hline \multicolumn{3}{|c|}{ سنة إجراء الدراسة } & \multicolumn{2}{|c|}{ جنس الباحث } & \multicolumn{2}{|c|}{ المرحلة } & \multicolumn{2}{|c|}{ الدرجة } & \multicolumn{2}{|c|}{ الجامعة } \\
\hline ar+l= $-r \cdots A$ & Ar..r-Y..o & ع..-rم فما دون & أثثى & ذكر & تعليه جامعي* & تعليم عام & دكتوراه & ماجستير & الملك سعود & أم القرى \\
\hline rr & v & $r$ & $\checkmark$ & rE & 0 & rq & 11 & r. & $\wedge$ & rr \\
\hline \multicolumn{3}{|c|}{$\$ 1$} & \multicolumn{2}{|c|}{$\$$} & \multicolumn{2}{|l|}{$\$ 1$} & \multicolumn{2}{|c|}{$\$ 1$} & \multicolumn{2}{|c|}{$\$ 1$} \\
\hline
\end{tabular}

* رسـالتين منها تتعلق بـانكليات التقنية التابعة للمؤسسـة العامـة للتعليهم الفني والتدريب المهني: 


\section{منهج الدراسة:}

استخدم الباحث ِِّ هذه الدراسـة المنهج المسحي، والمنهج الوصفي التحليلي ( Descriptive

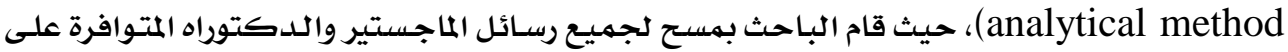

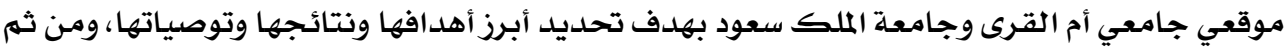

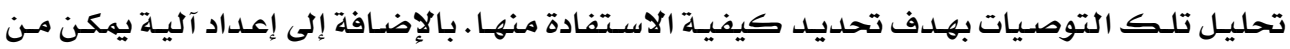

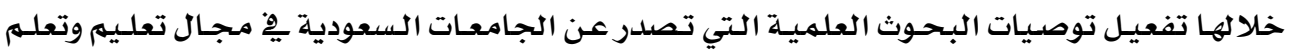
الرياضيات.

\section{إجراءات الدراسية:}

ا. مسـح الرسائل العلمية الصادرة عن قسهم المناهج وطرق التدريس بجامعـة أم القرى بهكة المكرمسة

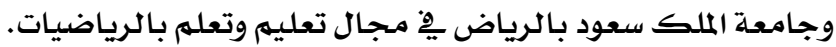

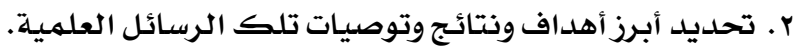

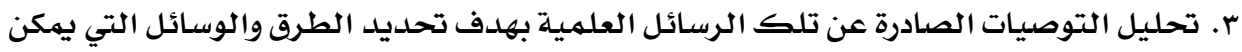

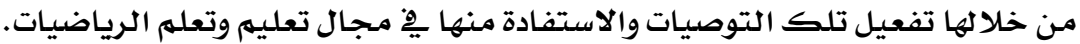

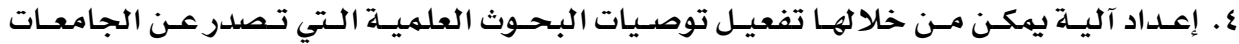

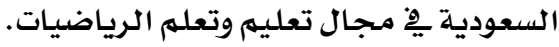

نتائج الدراسة

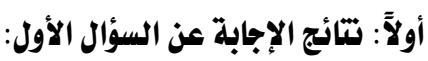

كان السؤال الأول من أسئلة الدراسـة على النحو التالي:

مـا هـي أبـرز أهـداف ونتـائج وتوصـيات البحـوث العلميـة الـتي أجريـت ِِّ المملكـة العربيـة

السعودية يْ مجال تعليم وتعلم الرياضيات \&.

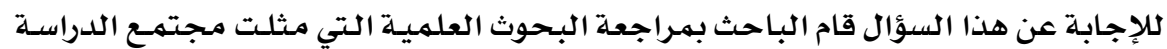

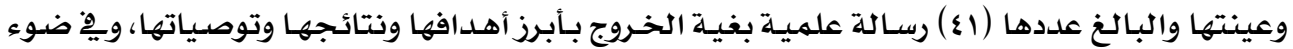

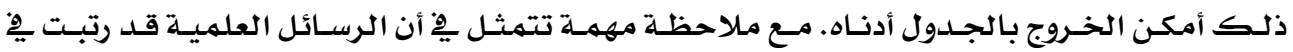

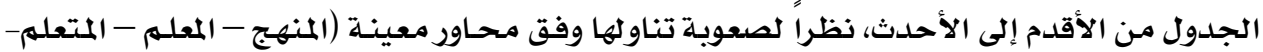

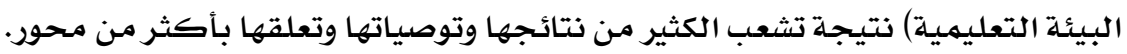
ويوضح الجدول رقم (r) أبرز أهداف ونتائج وتوصيات الرسائل العلميلة : 
جدول رقم (r) : أبرز أهداف ونتائج وتوصيات الرسائل العلمية التي أجريت ِِ المملكة العربية السعودية مِّْ مجال تعليه وتعله الرياضيات

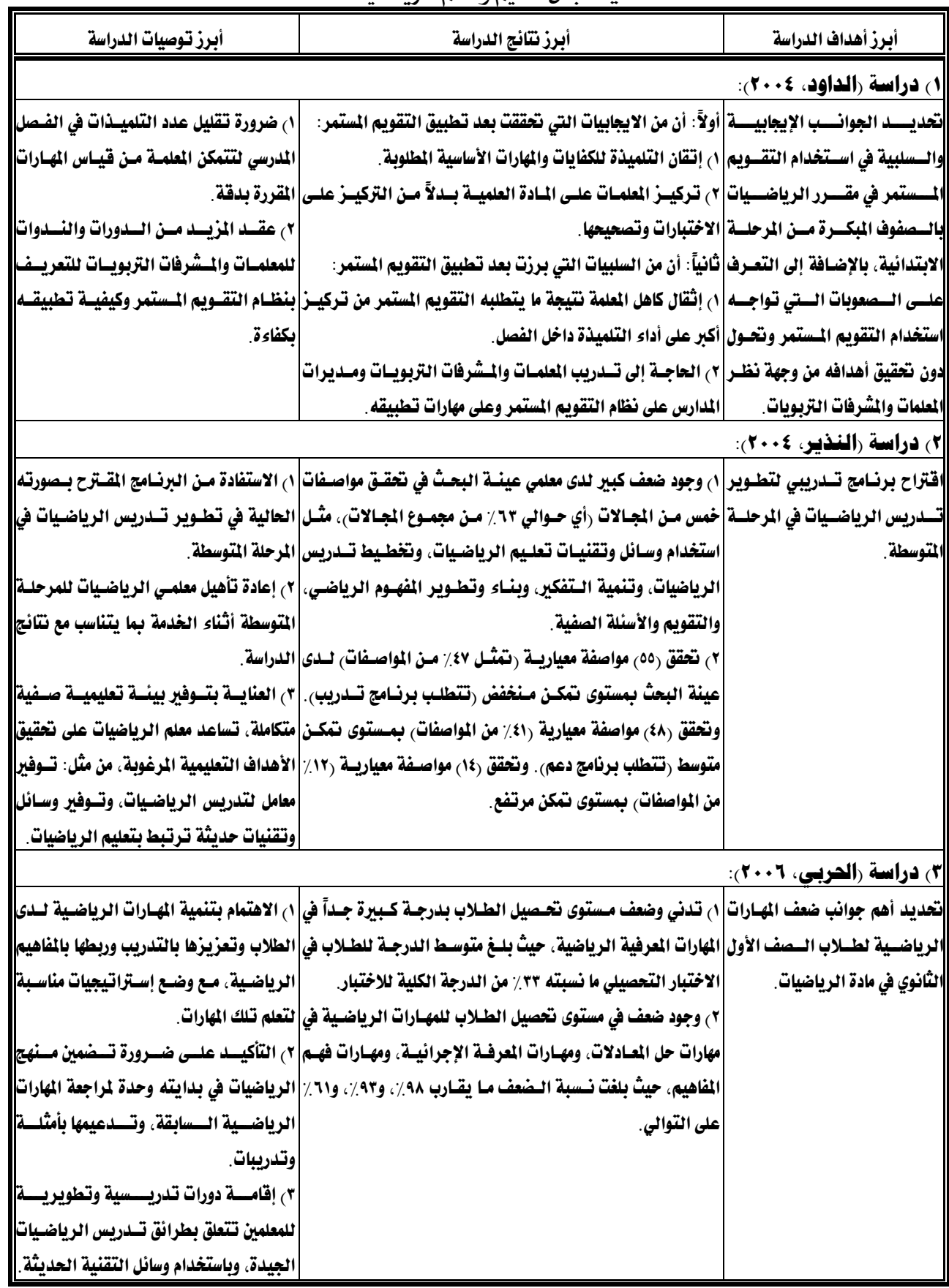




\begin{tabular}{|c|c|c|}
\hline أبرز توصيات اللدراسة & أبرز تتائج الدراسة & أبرز أهداف الدراسة \\
\hline \multicolumn{3}{|r|}{ 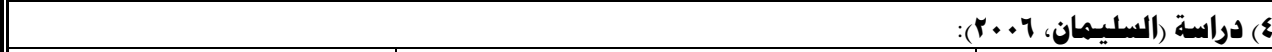 } \\
\hline 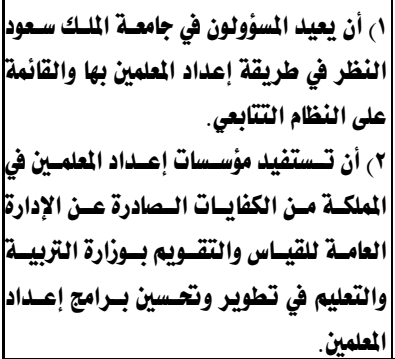 & 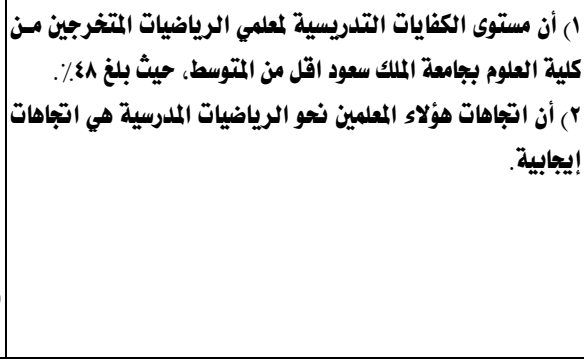 & 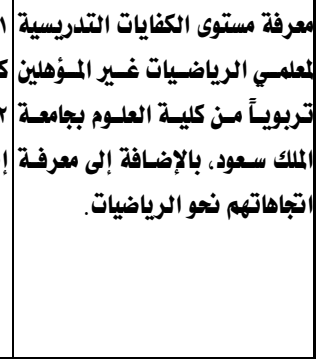 \\
\hline \multicolumn{3}{|r|}{ 0) دراسة (الهـمزاني، † +..ץ): } \\
\hline 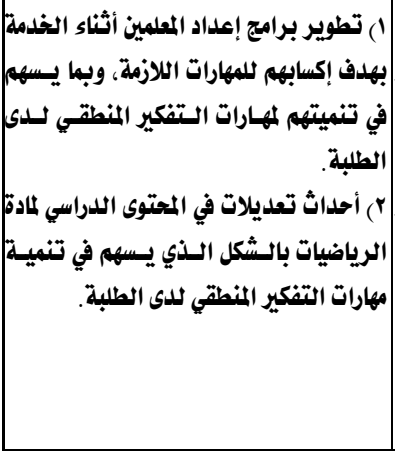 & 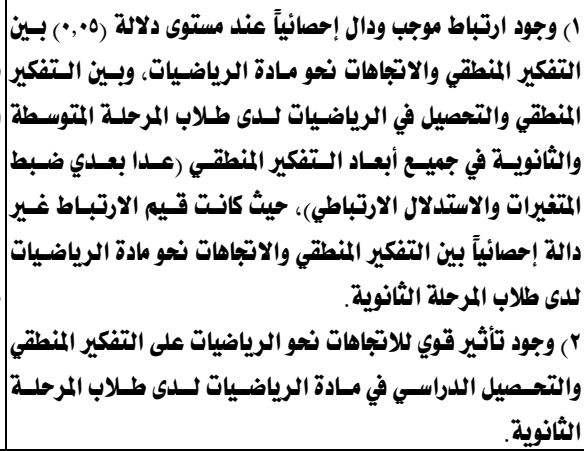 & 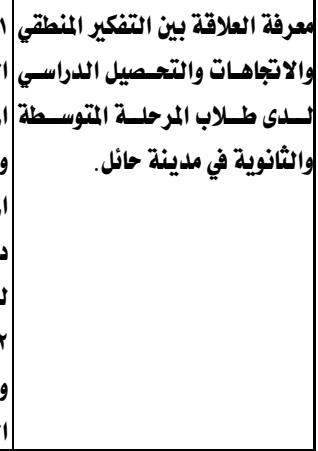 \\
\hline \multicolumn{3}{|r|}{ 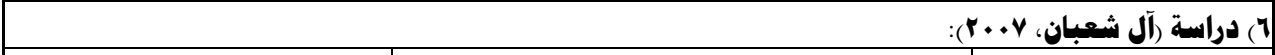 } \\
\hline 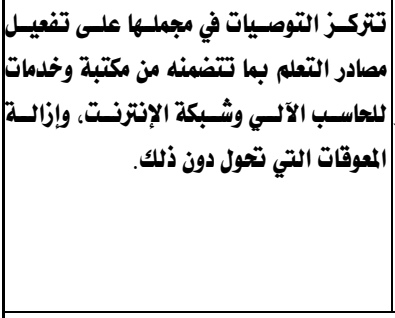 & 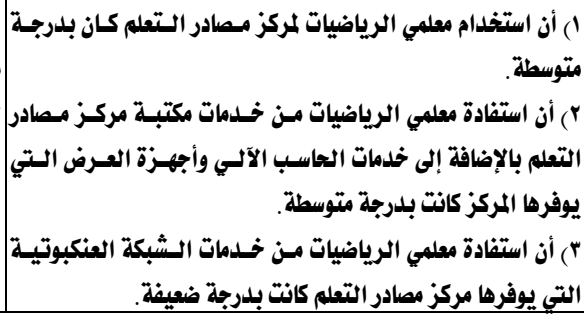 & 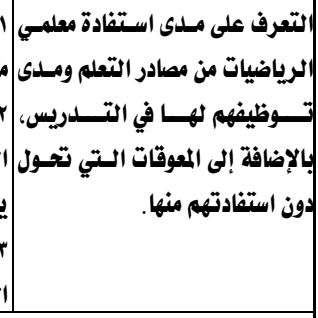 \\
\hline \multicolumn{3}{|c|}{ V) دراسة (الرحيلي، V • +r): } \\
\hline 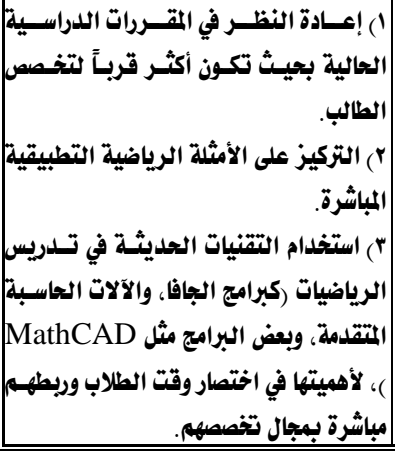 & 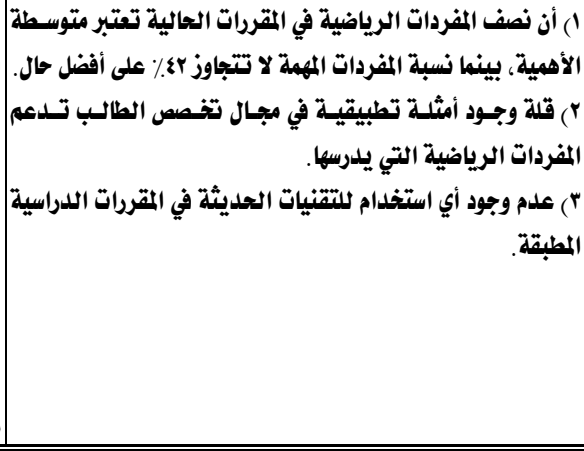 & 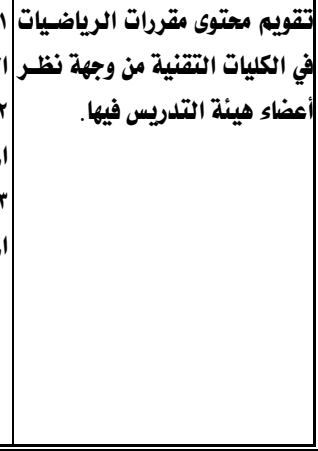 \\
\hline
\end{tabular}




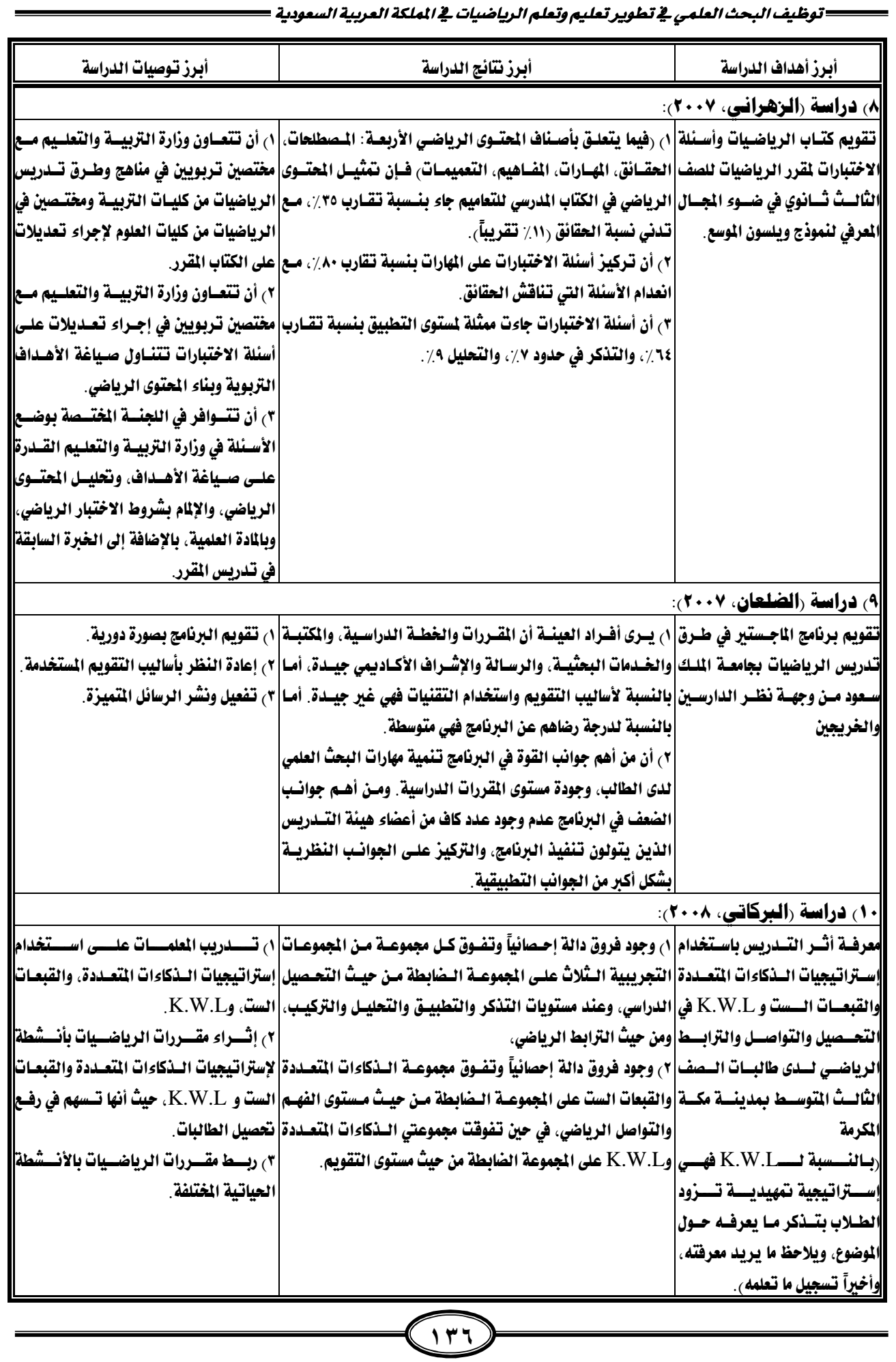




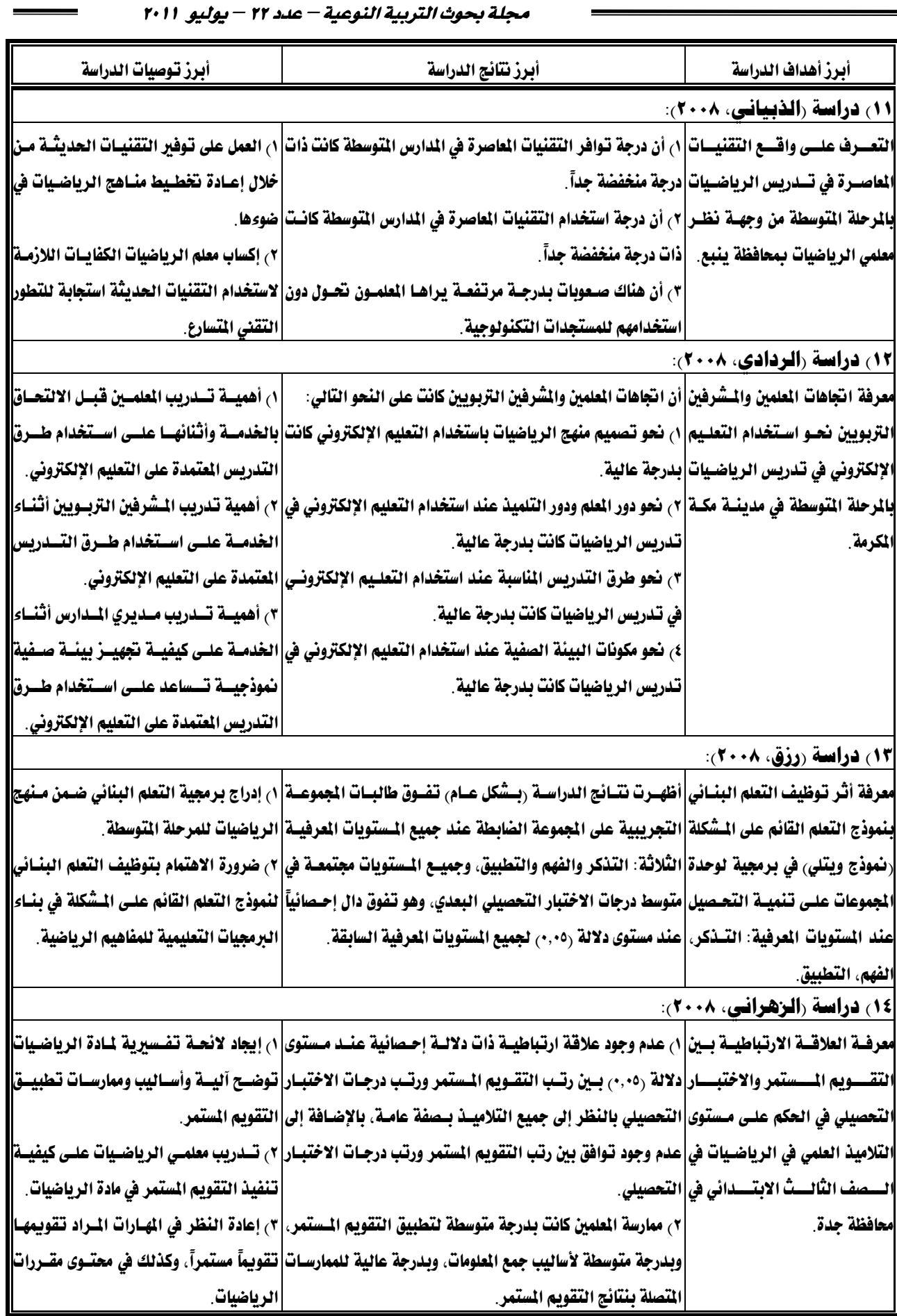


سب توظيف البحث العلهمي فِ تطوير تعليه وتعله الرياضيات فِ المملكة العريية السعودية

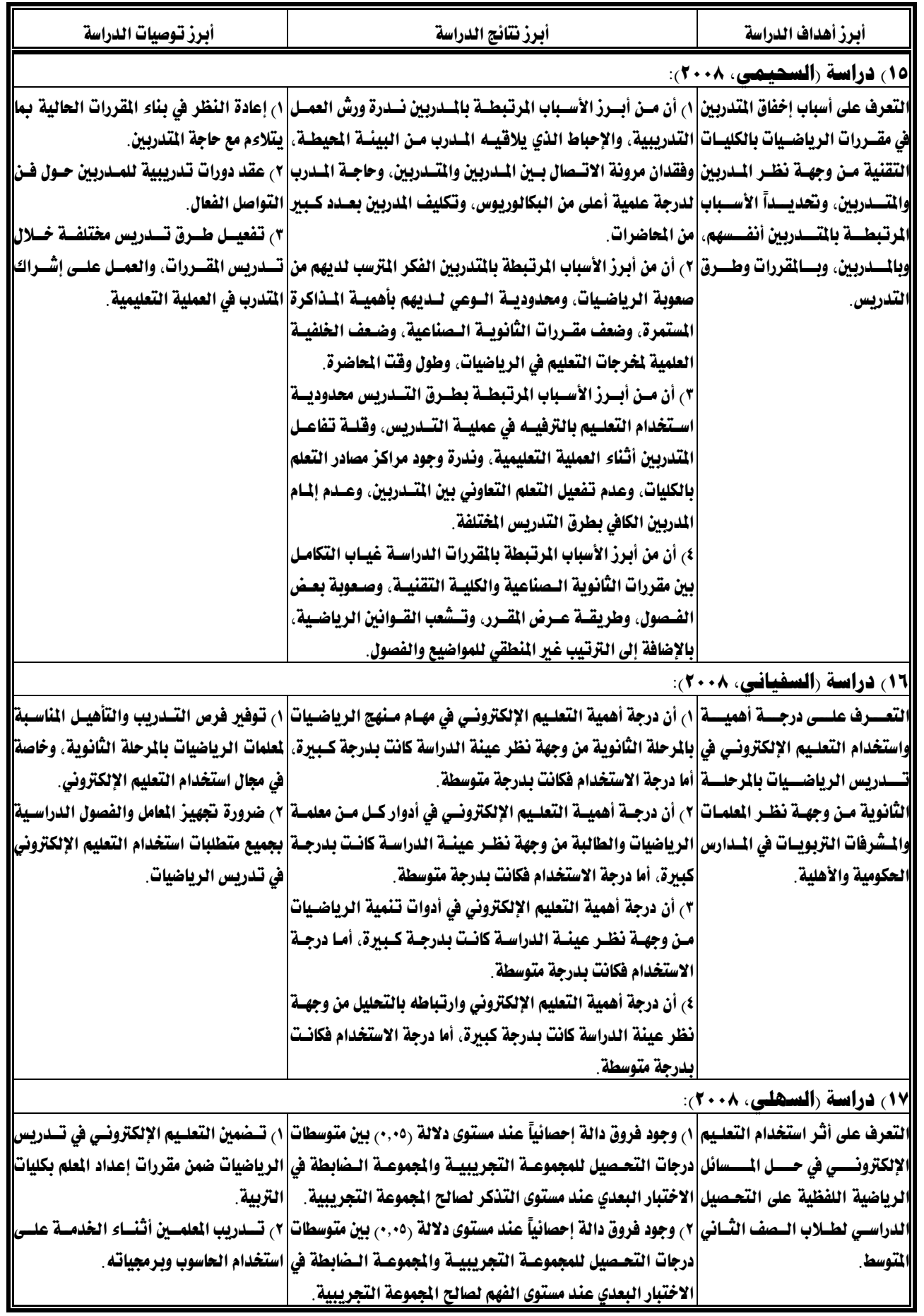




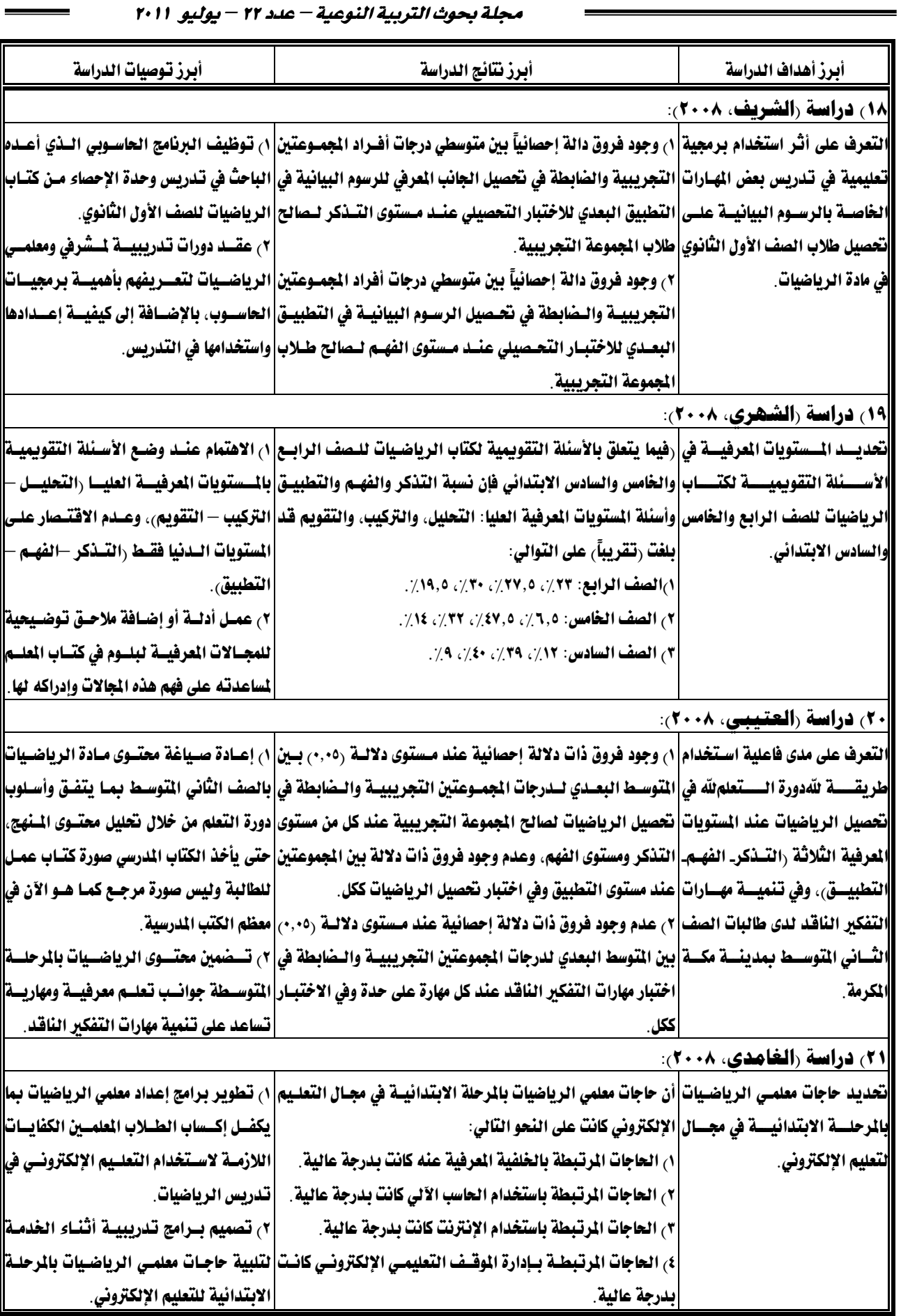




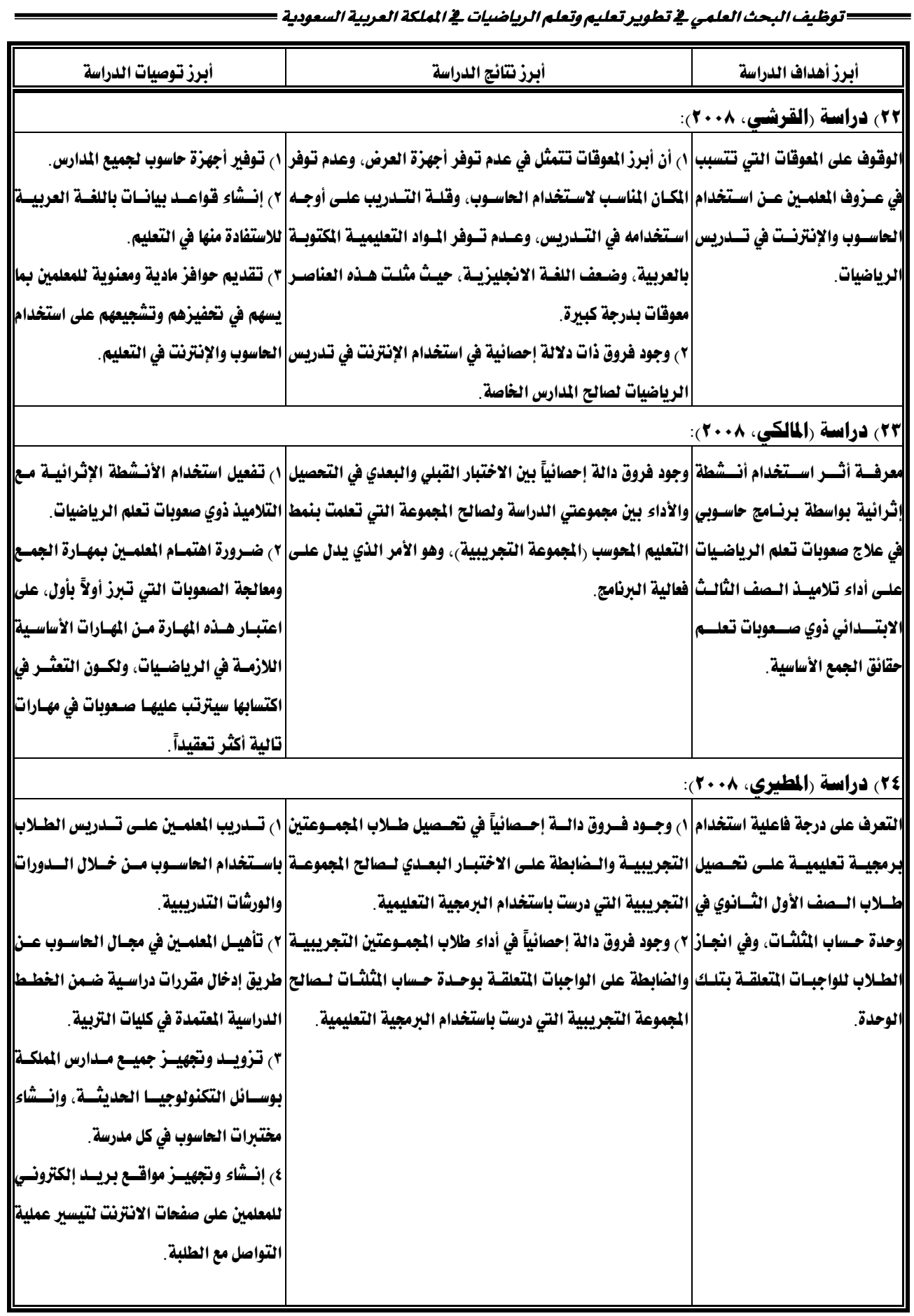




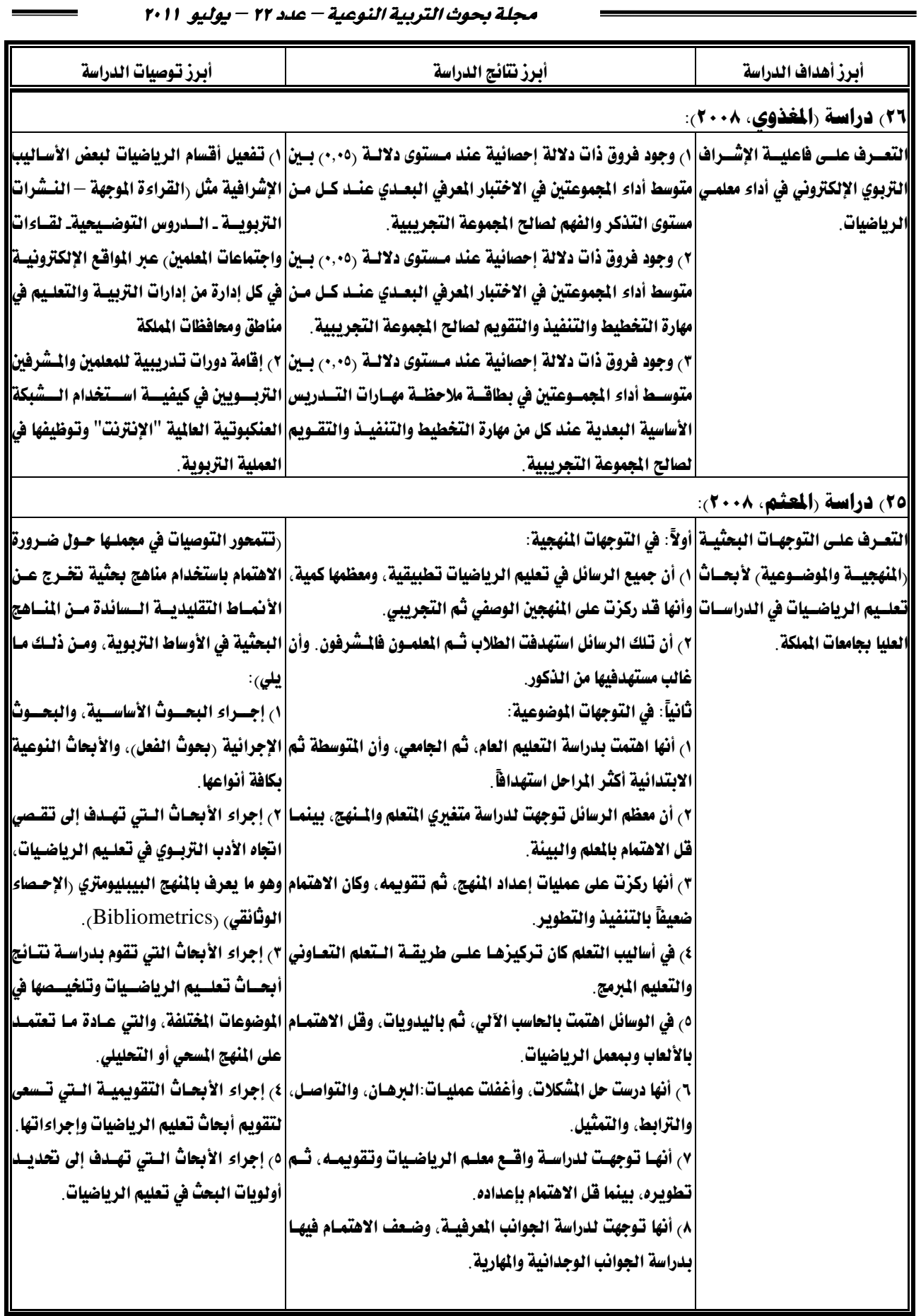




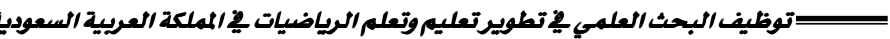

\begin{tabular}{|c|c|c|}
\hline أبرز توصيات الدراسة & أبرز تتائج الدراسة & أبرز أهداف الدراسة \\
\hline \multicolumn{3}{|r|}{ Vץ) دراسة (الاقاطي، ^• • +): } \\
\hline 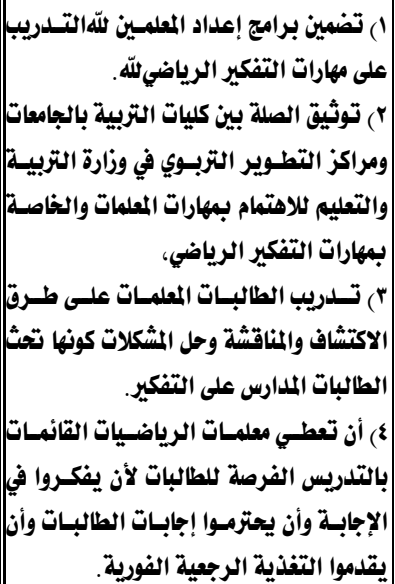 & 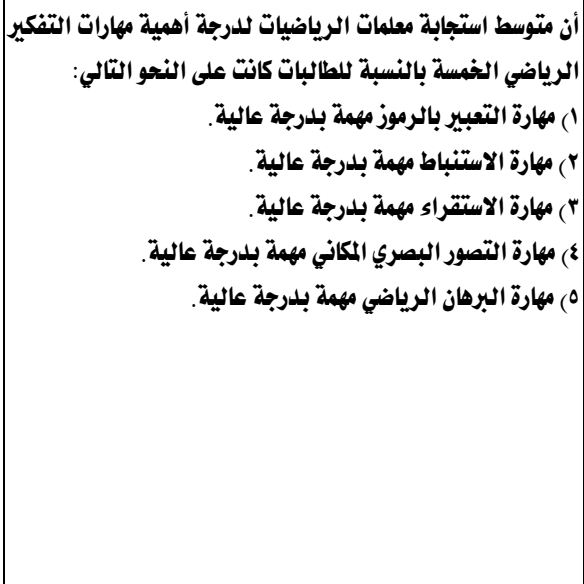 & 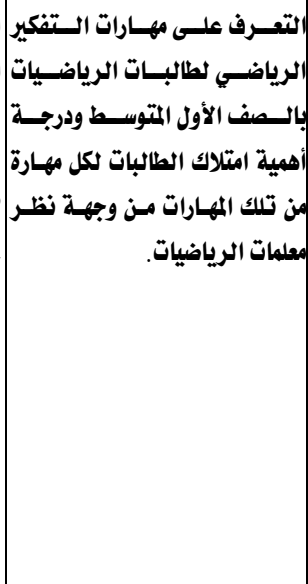 \\
\hline \multicolumn{3}{|r|}{ 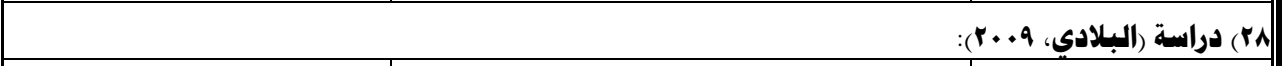 } \\
\hline 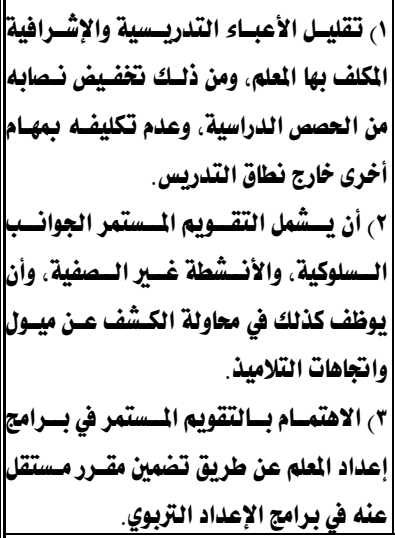 & 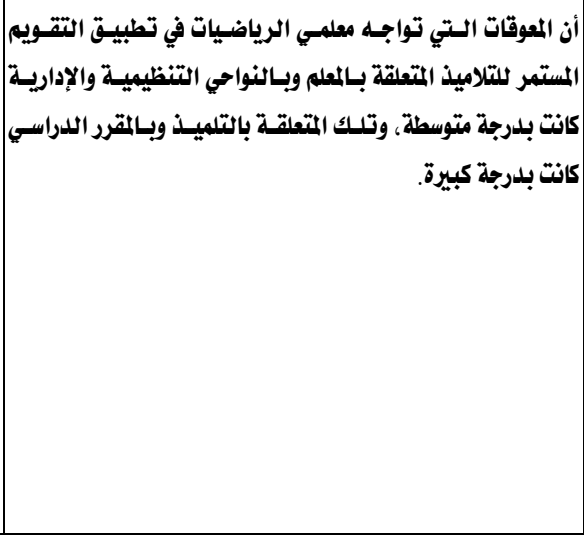 & 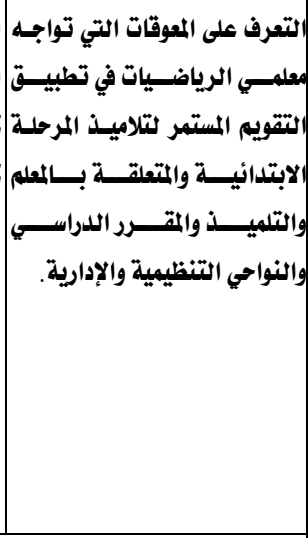 \\
\hline \multicolumn{3}{|r|}{ 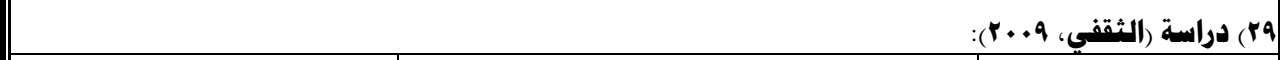 } \\
\hline 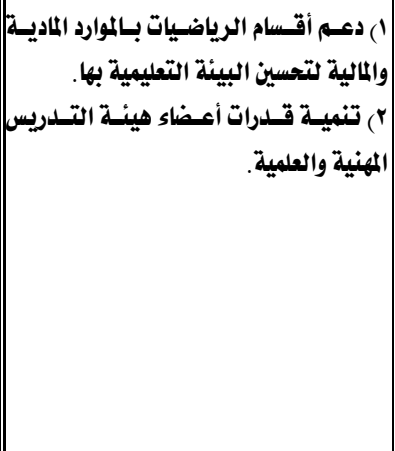 & 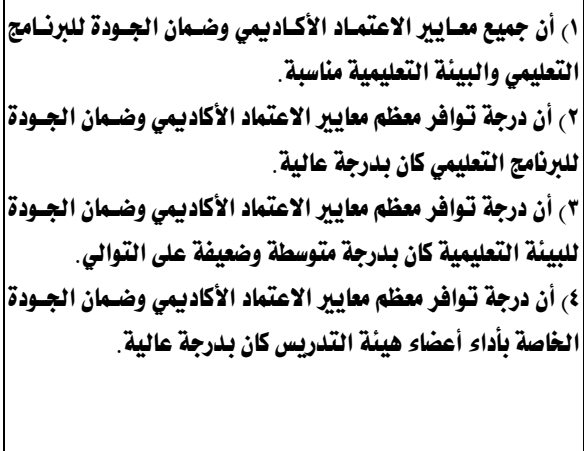 & 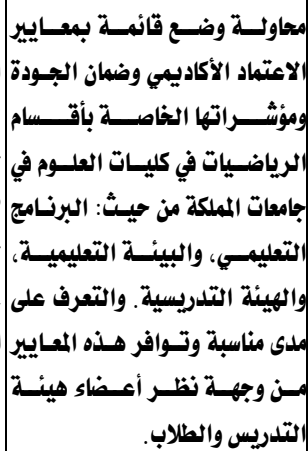 \\
\hline
\end{tabular}




\begin{tabular}{|c|c|c|}
\hline أبرز توصيات الدراسة & أبرز تتائج الدراسة & أبرز أهداف الدراسة \\
\hline \multicolumn{3}{|c|}{ 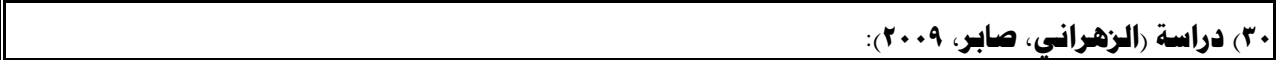 } \\
\hline 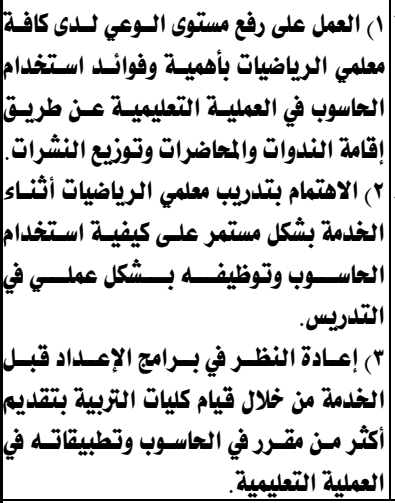 & 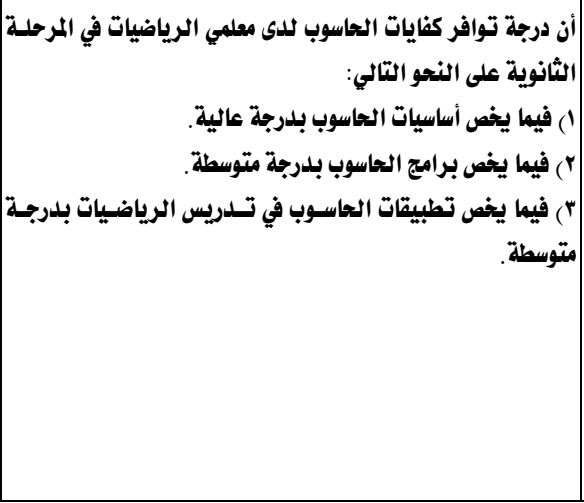 & |التعرف على درجة تــوافر كفايـات \\
\hline \multicolumn{3}{|c|}{ 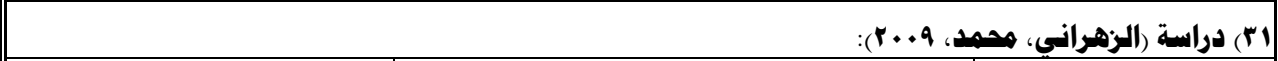 } \\
\hline 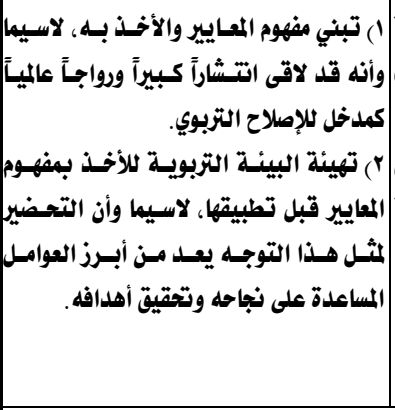 & 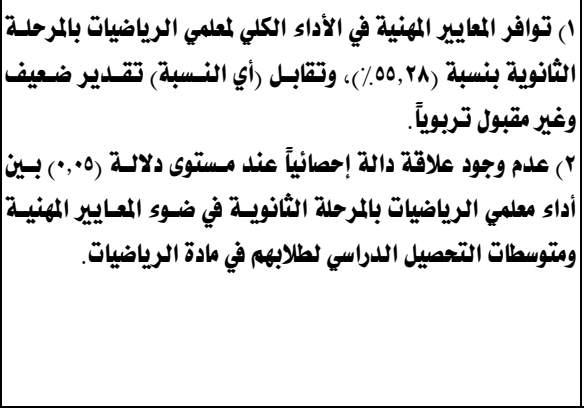 & 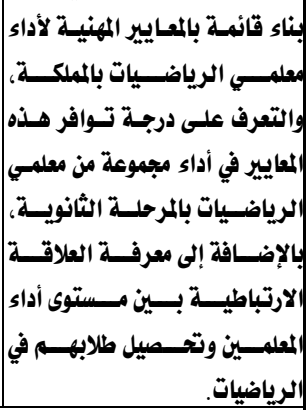 \\
\hline \multicolumn{3}{|c|}{ 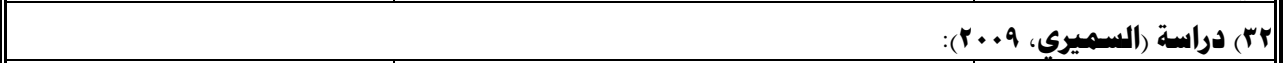 } \\
\hline 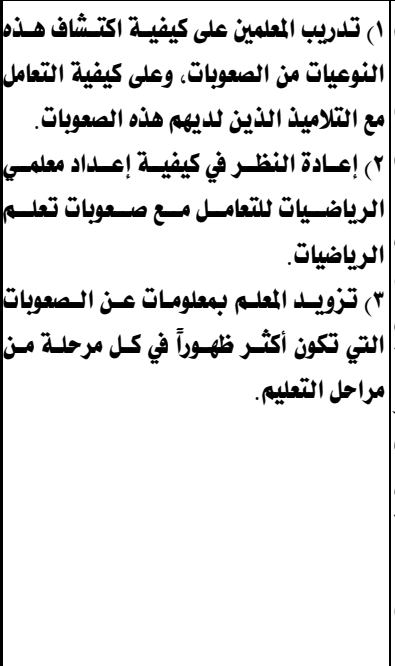 & 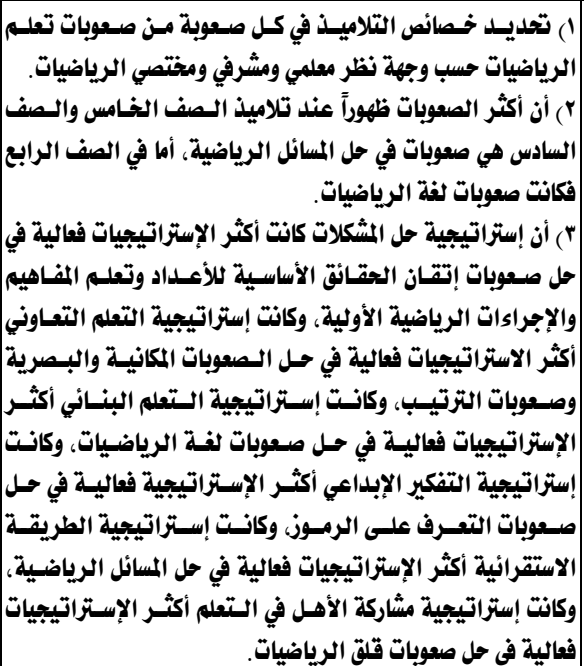 & 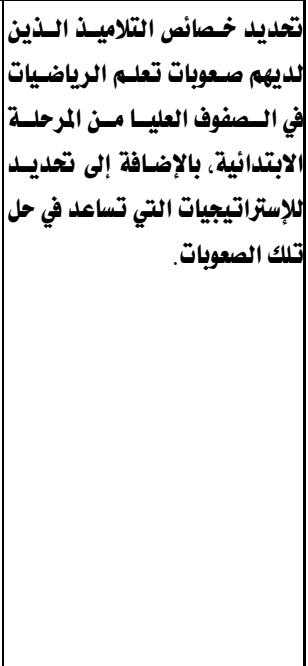 \\
\hline
\end{tabular}




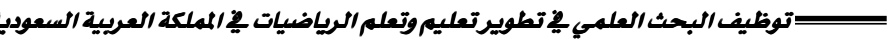

\begin{tabular}{|c|c|c|}
\hline أبرز توصيات الدراسة & أبرزتتائج الدراسة & أبرز أهداف الدراسة \\
\hline \multicolumn{3}{|r|}{ rr) دراسة (العنري، 9 × + r): } \\
\hline 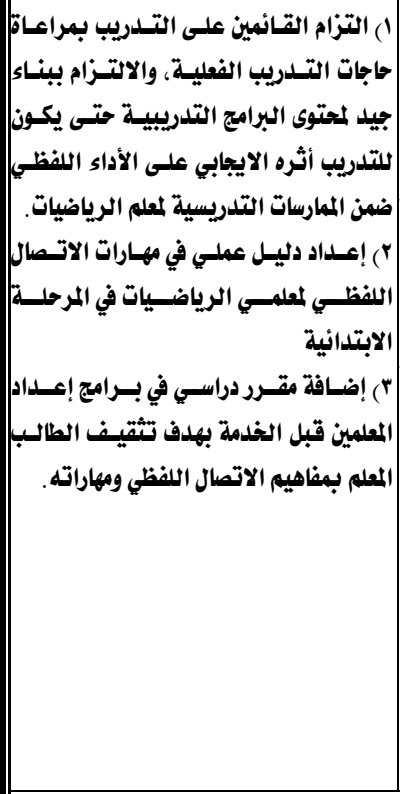 & 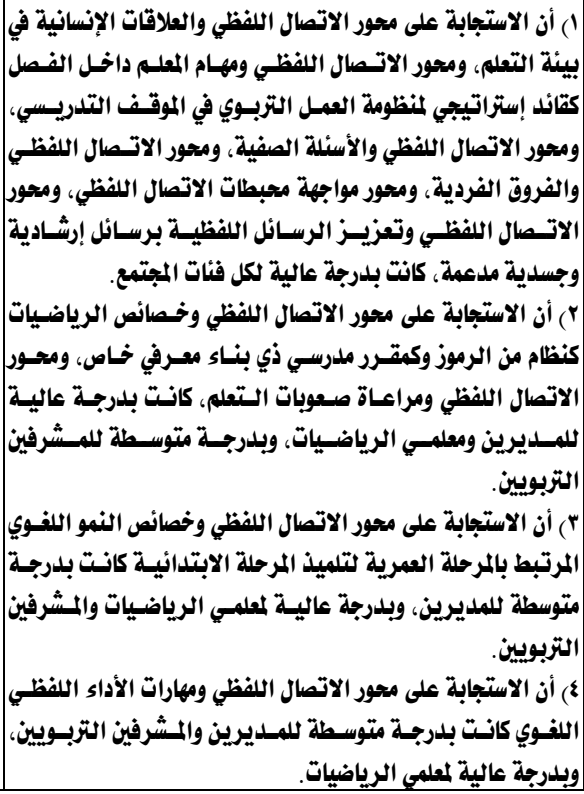 & 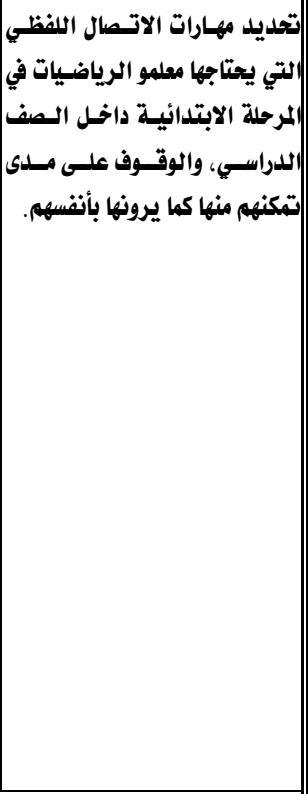 \\
\hline \multicolumn{3}{|r|}{ 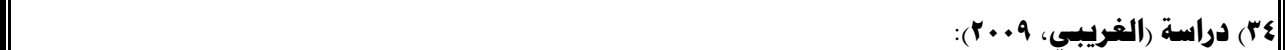 } \\
\hline 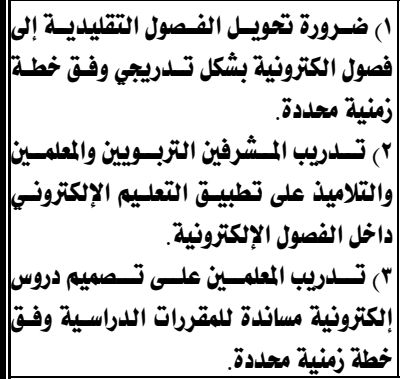 & 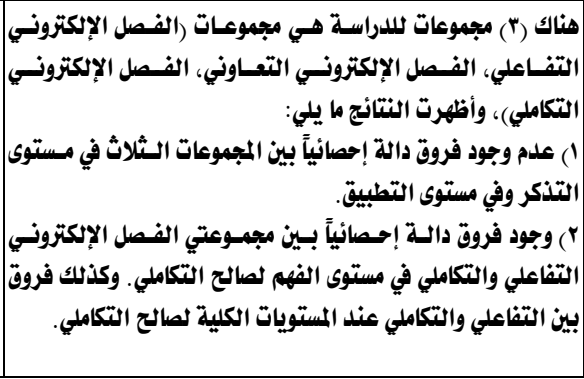 & 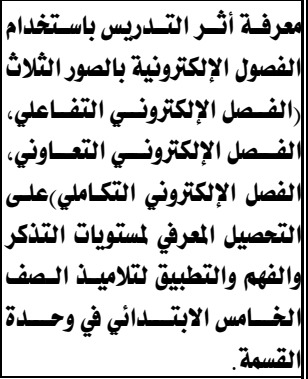 \\
\hline \multicolumn{3}{|r|}{ مr) دراسة (القرشي، 9 ×. r): } \\
\hline 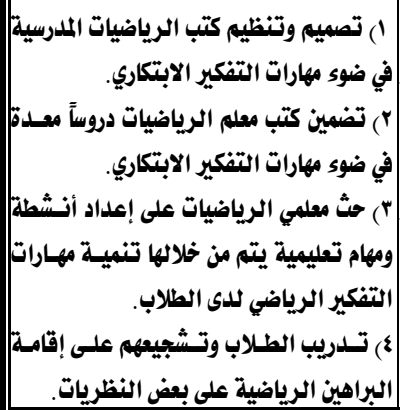 & 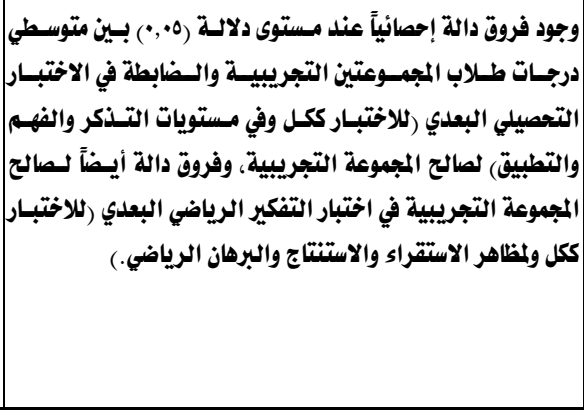 & 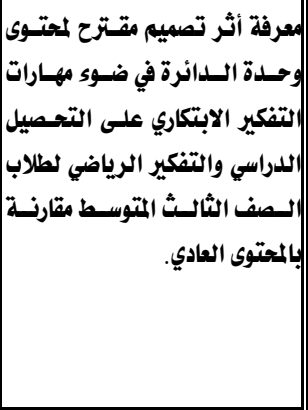 \\
\hline
\end{tabular}




\begin{tabular}{|c|c|c|}
\hline أبرز توصيات الدراسة & أبرز تتائج الدراسة & أبرز أهداف الدراسة \\
\hline & & دراسة (المالكي، 9 × + ץ): \\
\hline 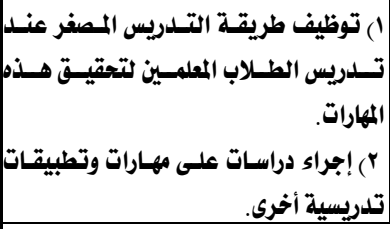 & 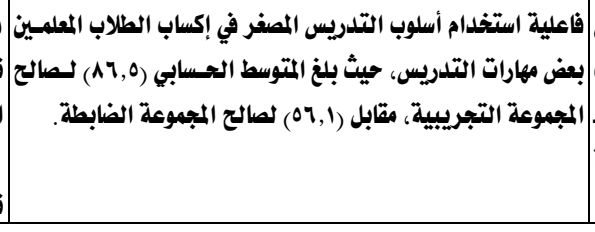 & 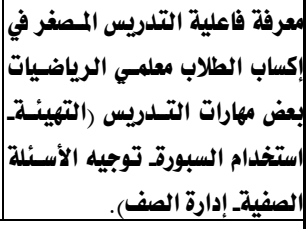 \\
\hline \multicolumn{3}{|r|}{ קr) دراسة (الودعاني، 9 . + r): } \\
\hline 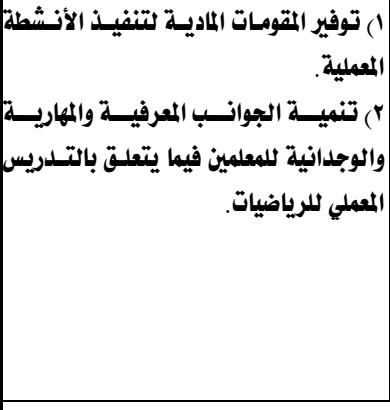 & 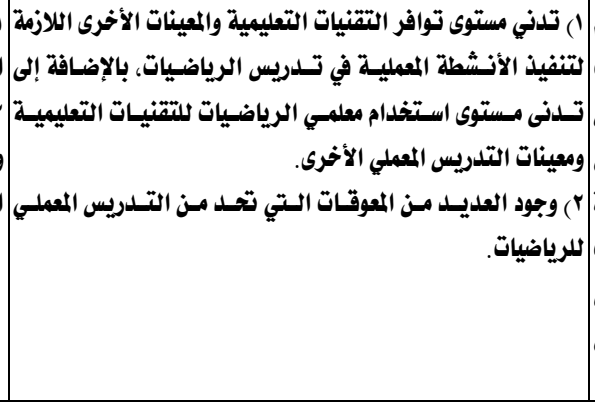 & 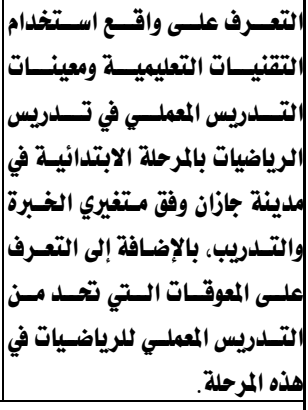 \\
\hline \multicolumn{3}{|r|}{ 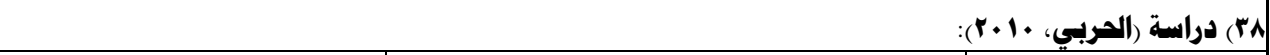 } \\
\hline 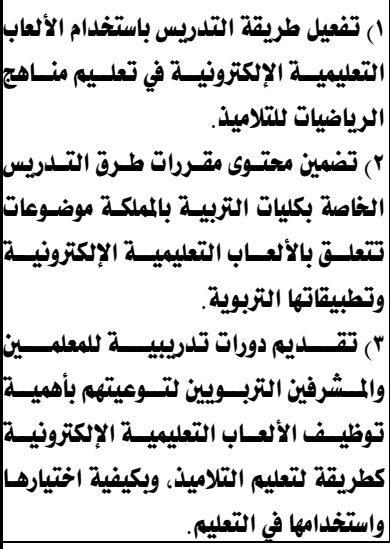 & 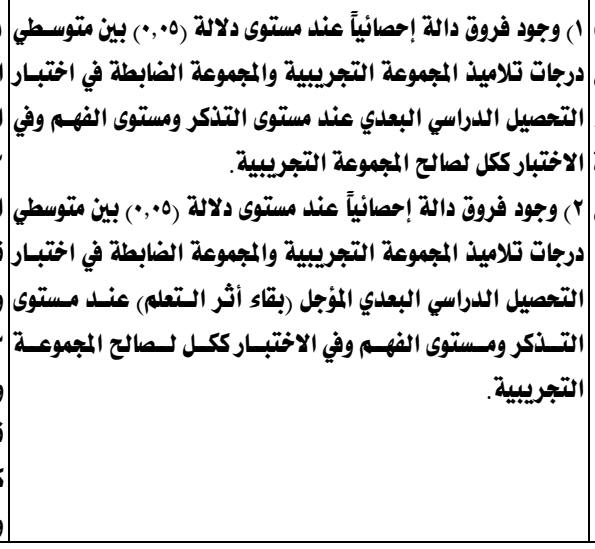 & 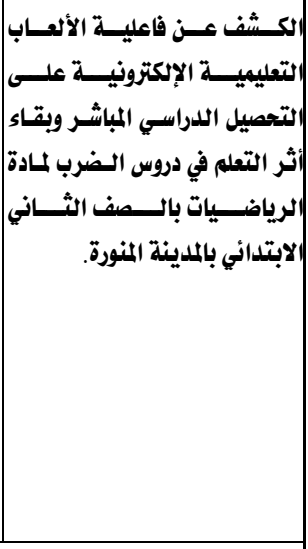 \\
\hline \multicolumn{3}{|c|}{ 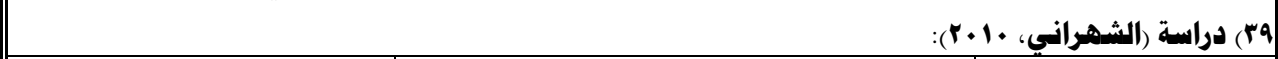 } \\
\hline 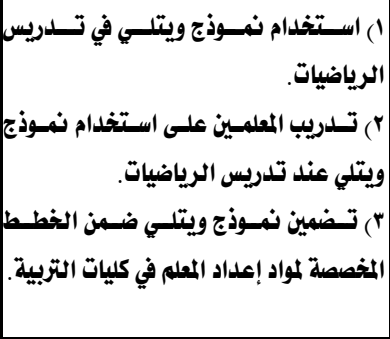 & 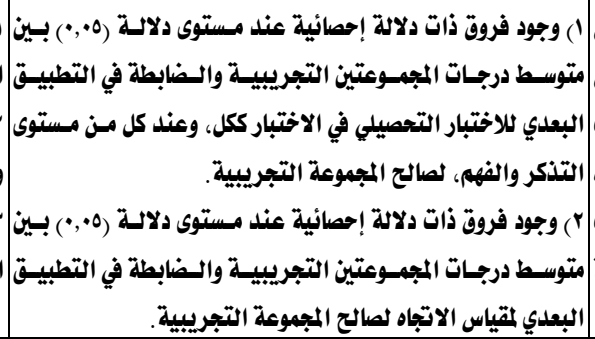 & 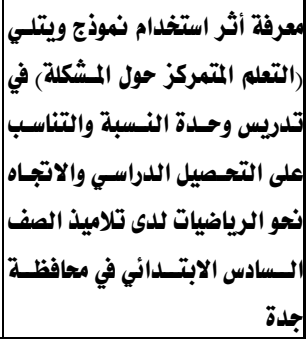 \\
\hline
\end{tabular}




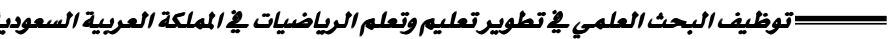

\begin{tabular}{|c|c|c|}
\hline أبرز توصيات الدراسة & أبرز تتائج الدراسة & أبرز أهداف الدراسة \\
\hline \multicolumn{3}{|c|}{ 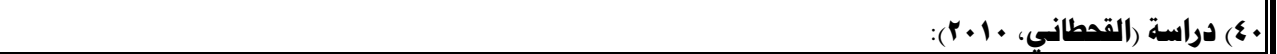 } \\
\hline 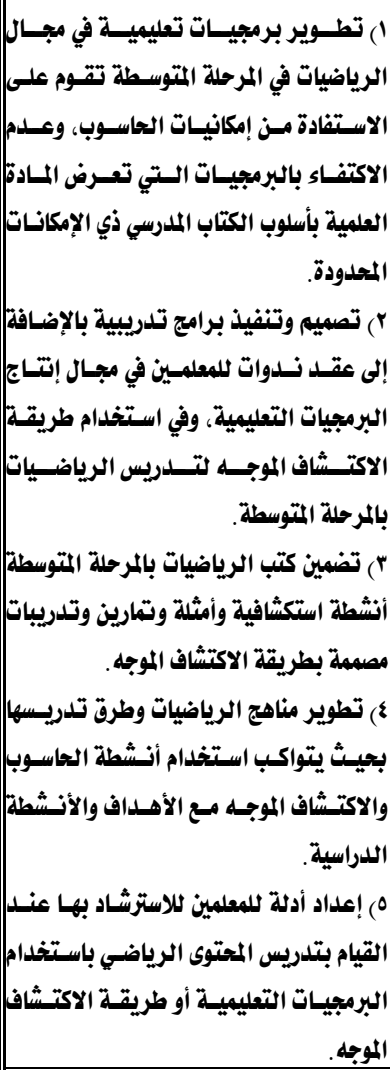 & 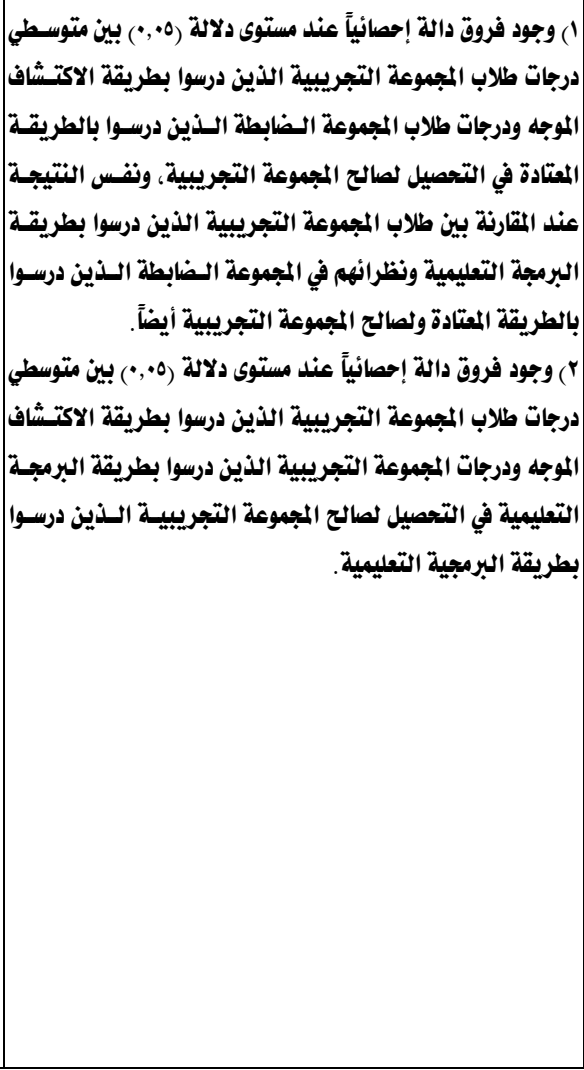 & 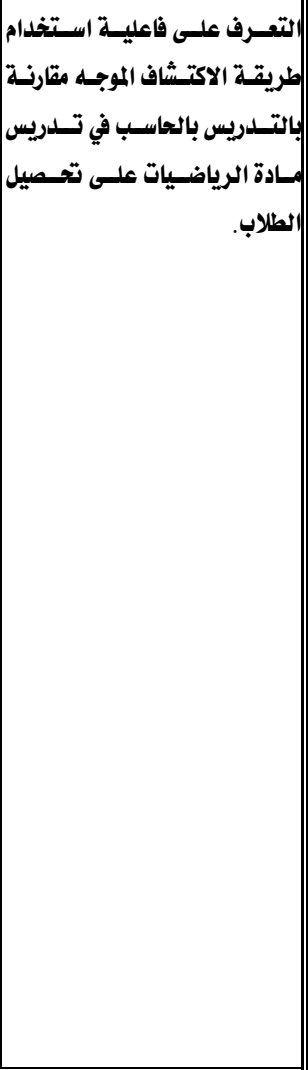 \\
\hline & & 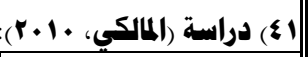 \\
\hline 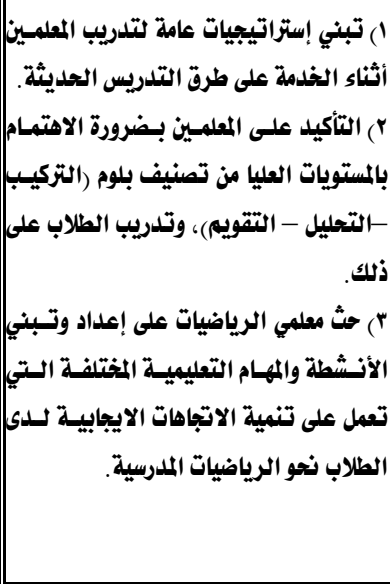 & 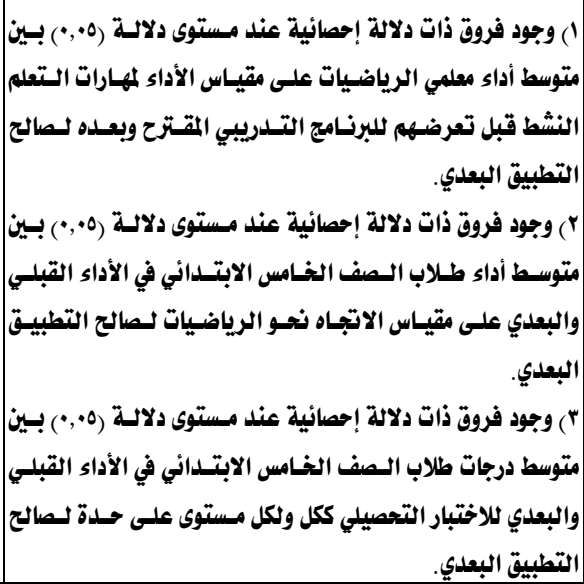 & 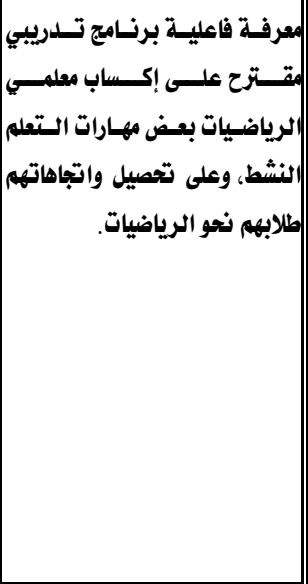 \\
\hline
\end{tabular}


ثانياً: تتائج الإجابة عن السؤال الثاني:

كان السؤال الثاني من أسئلة الدراسـة على النحو التالي:

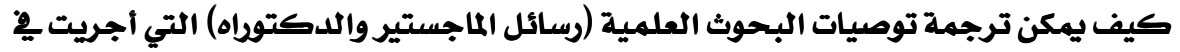

المملكة العربية السعودية ِِ مجال تعليم وتعلم الرياضيات إلى توصيات عملية وقابلة للتطبيقهُ

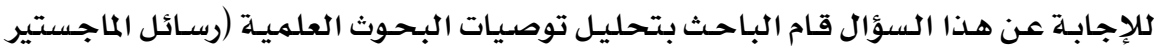

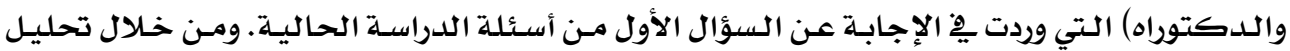

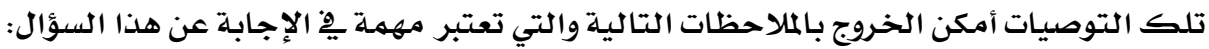

ملاحظات على توصيات البحوث العلمية المشار إليها أعلاه:

$$
\text { من أبرز تلك الملاحظات ما يلي: }
$$

أولاً : أن الجهات التي يمكن لها الاستفادة من توصيات تلك البحوث تتمثل ِِّ (r) جهات رئيسـة هي:

$$
\text { ( ) ) وزارة التربية والتعليه. }
$$

r) المؤسسة العامـة للتعليم الفني والتدريب المهني.

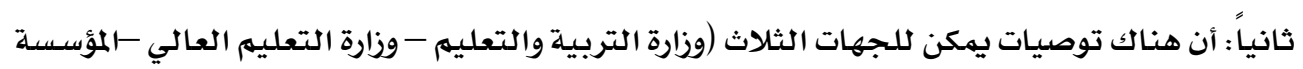

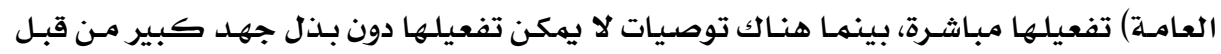

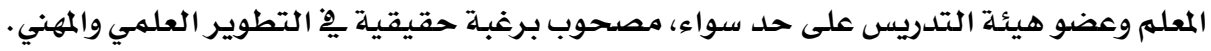

ثالثاً : أن الجزء الأكبر من تلك التوصيات يمكن ترجمتها إلى توصسيات عمليـة وقابلـة للتطبيق عن

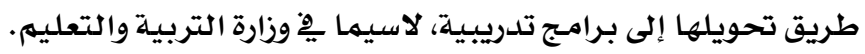

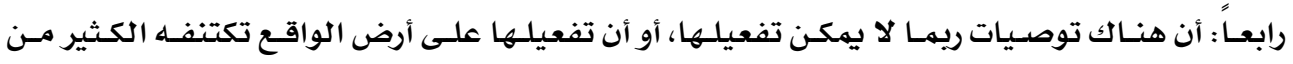

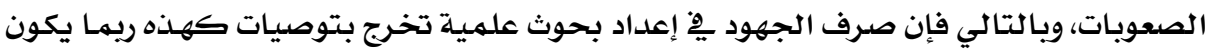

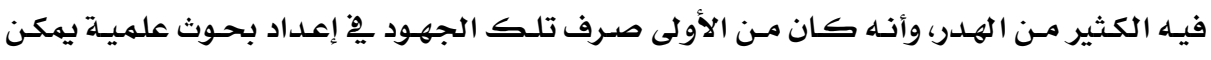

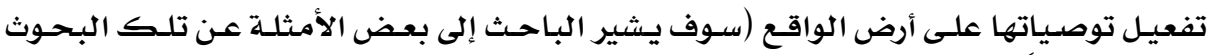
العلمية لاحقاً) .

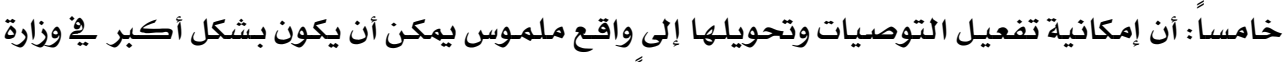

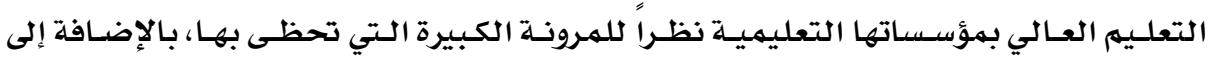

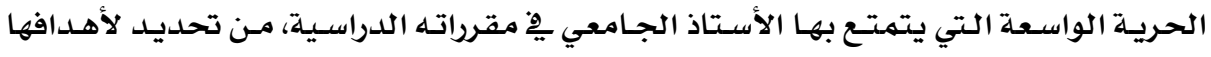

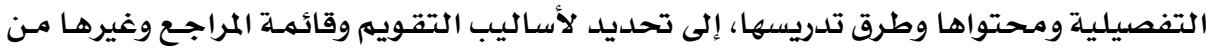

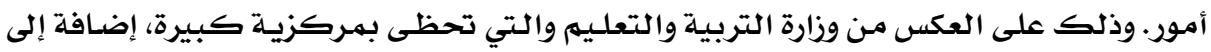

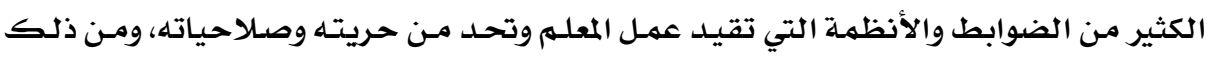




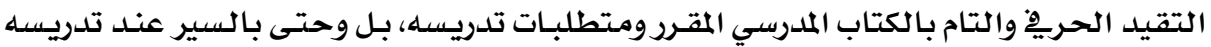

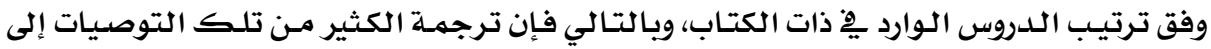

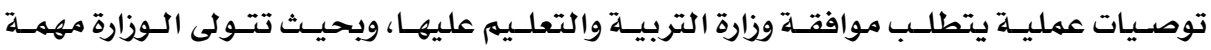

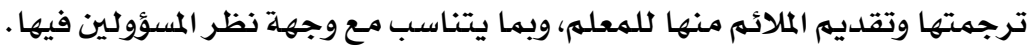
ويـود الباحث الإثـارة إلى أن تلـك التوصسيات العمليـة والقابلـة للتطبيـق سـيتم تناولها وفتق

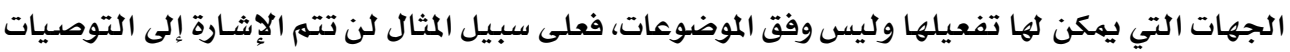

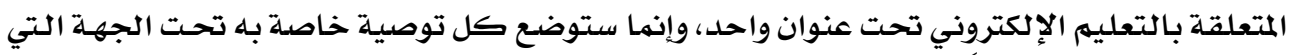

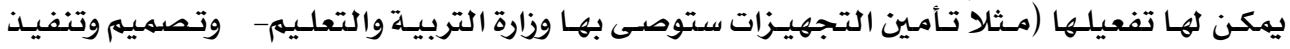

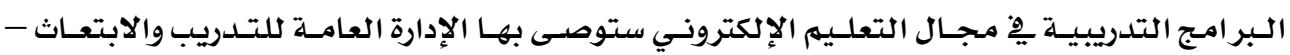

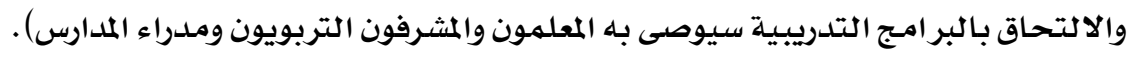

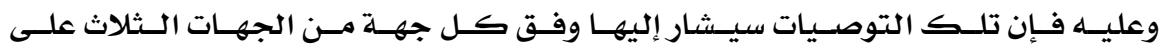
النحو التالي: والمها:

\section{الجهة الأولى: وزارة التزبية والتعائيم:}

ستــشمل التوصــيات وزارة التربيــة والتعلــيم بإداراتهــا المعنيــة، بالإضــافة إلى توصـيـات

خاصسة بالمعله.

وتركز التوصيات الخاصة بالوزارة على مجالين رئيسين هما :

$$
\begin{aligned}
& \text { أولاً: البر امـج التدريبية. } \\
& \text { ثانياً: الدعم المادي والإداري والتقني. }
\end{aligned}
$$

أما بالنسبة للتوصيات الخاصة بالمعلهم فتتركز على ثلاثة مجالات رئيسة، هي:

$$
\text { ثالثاًً: }
$$

وسـوف يتهم تنـاول ذلك بالتفصيل على النحـو التالي مبتـدئين بـدوروزارة التربيـة والتعلسيم

\section{أولاً: البراهمج التدريبة المعية:}

يمكن ترجمة جزء من تلك التوصيات إلى عدد من البر امـج التدريبية الموجهة إلى (r) فئسات

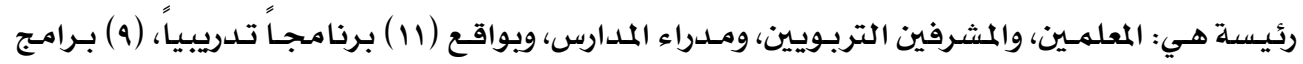

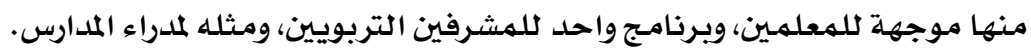

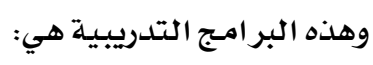


1) البرامج التدريبية للمعلمين:

يوصى بتصميم وتنفيذ البر امج التدريبية التالية:

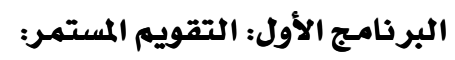

من حيث:

• التعريف بنظام التقويم المستمر.

• كيفية تطبيق نظام التقويم المستمر بِّ مادة الرياضيات بكفاءة.

البرنامج الثاني: التدريس المعملي للرياضيات:

بحيـث يسعى البرنـامج إلى تنميـة الجوانـب المعرفيـة والمهاريـة والوجدانيـة للمعلمـين فيمـا

يتعلق بالتدريس المعملي للرياضيات.

البرنامـج الثالث: الحاسوب :

من حيث التركيز على استخدام الحاسوب وكيفية توظيفه يِّ التدريس بشكل عملي.

البرنامج الرابع: التعليم الإلكتروني:

بحيث يسعى البرنامـج إلى:

• التعريف بأهمية برمجيات الحاسوب وكيفية إعدادها وتوظيفها ِِي التدريس.

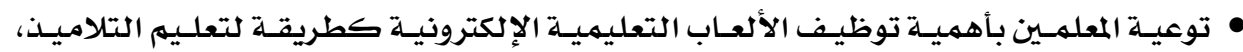

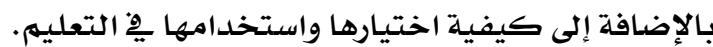

• تصميهم دروس الكترونية مساندة للمقررات الدراسية وفق خطة زمنية محلددة.

$$
\text { • • إنتاج البر مجيات التعليمية. }
$$

• استخدام الشبكة العنكبوتية العالمية "الإنترنت" وتوظيفها يِّة العملية التعليمية.

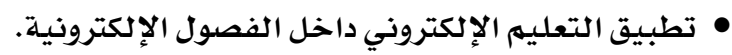

البرنامج الخامس: طرق وإستراتيجيات التدريس:

من حيث التركيز على طرائق تدريس الرياضيات الجيدة والحديثة وتوظيفها، ومـن ذلك:

• • استخدام نموذج ويتلي ِِّ تدريس الرياضيات للتلاميذ.

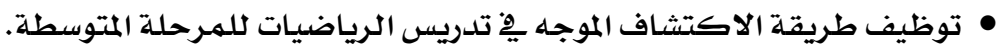

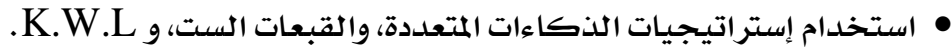

$$
\text { • استخدام طرق التدريس المعتمدة على التعليم الإلكتروني. }
$$

البرنامـج السادس: التواصل اللفظي :

من حيث التدريب على الأداء اللفظي ضمن الممارسات التدريسية لمعلم الرياضيات. 


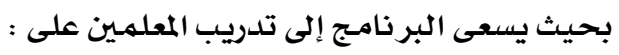$$
\text { • • بكيفية اكتشاف ذوي صعوبات التعله. }
$$$$
\text { • كيفية التعامل معهمه. }
$$

البرامج الثامن: التقنيات الحديثة:

بحيث يسعى البر نامـج إلى إكساب معلمى الرياضيات الكفايـات اللازمـة لاستخدام التقنيـات

الحديثة بها يتناسب مـع التطور التقني المتسارع. البرامج التاسع: مهارات التفكير:

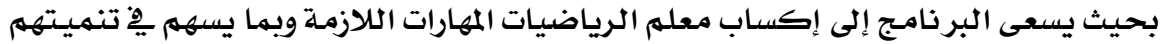

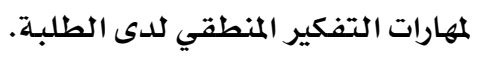

\section{ץ البرنامج التدريبي للمشرفين التربويين:}

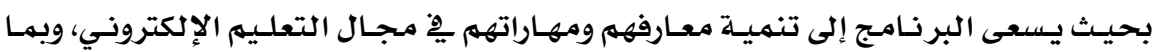

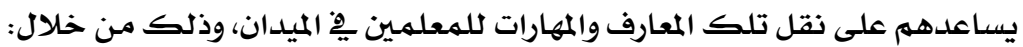

• تعريفهم بأهمية برمجيات الحاسوب وكيفية إعدادها وتوظيفها يِ التدريس.

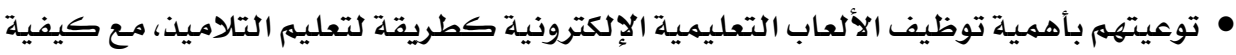

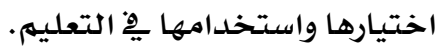

$$
\text { • • كيفية استخدامهم لطرق التدريس المعتمدة على التعليم الإلكتروني. }
$$

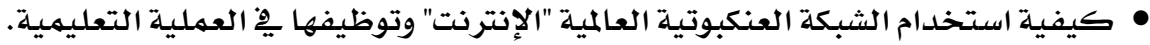

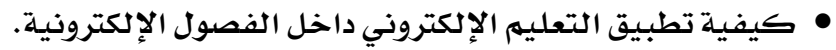

r) البرنامج التدريبي لملدراء الملدارس:

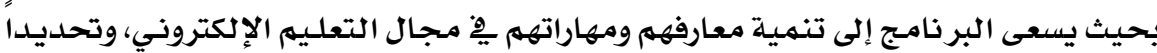

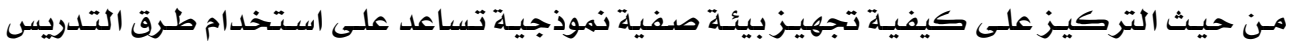

المعتمدة على التعليهم الإلكتروني.

\section{ثانيًا: الدعم المادي والإداري والتقدي: الإكتروني:}

يهدف هذا الدعم إلى تطوير البيئة المادية والبشرية يِّ العملية التعليمية من خلال التالي:

ا) توفير اللدم اللازم تجاه معلمبي الرياضيات:

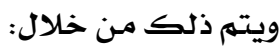

• تقليل الأعباء التدريسية والإشرافية المكلف بها المعله، ومن ذلك تخفيض نصابه من الحصص الحص

الدراسية، وعدم تكليفه بهمام أخرى خارج نطاق التدريس. 
مجلة بحوث التربية النوعية - علدد rr - بيوليو $\quad$ r.ll

• تقـــيهم حـوافز مـاديـة ومعنويـة للمعلمـين بهـا يـسهم هِ تحفيـزهم وتشجيعهم على اسـتخدام الحاسوب والإنترنت يِ التعليهم.

• توفير الدعم اللازم للإدارة العامـة للتدريب والابتعاث لتصميهم وتنفيـذ البر امج التدريبيـة المشار إليها أعلاه.

\section{r توفير اللدعم اللازم تجاه البيئة الصفية:}

ويتم ذلك من خلال:

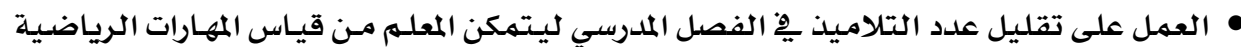

$$
\text { المقررة بدقة. }
$$

• العهل على تحويـل الفـول التقليديـة إلى فصول الكترونيـة بشكل تــريجي ووفق خطـة زمنيـة

$$
\text { مححلددة. }
$$

ץ) توفير اللدعم اللازم تجاه مصادر التعلم بالمدرسة:

وذلك من حيث العناية بتوفير بيئة تعليميلة صفية متكاملسة تسـاعد معلمم الرياضـيات على

تحقيق الأهداف التعليميـة المرغوبة.

ويتم ذلك من خلال:

• تجهيز المعامل بجميع متطلبـات استخدام التعليم الإِكتروني يِّندريس الرياضيات. • تزويد وتجهيز جميع مدارس المملكة بوسائل التكنولوجيا الحديثة، وإنشاء مختتبر ات الحاسـوب

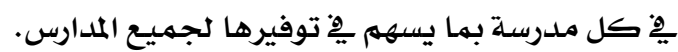
• تـوفير معامـل لتدريس الرياضـيات، وتجهيزهـا بـالوسـائل والتقنيـات الحلديثـة المرتبطـة بتعلـيم الرياضيات. • العمل على إزالة المعوقات التي تحول دون تفعيل مصسادر التعلم (من قبل المعلمـين ) بهـا تتضمنهـ من مكتبـة وخلدمات للحاسب الآلي وشبكة الإنترنت. • توفير المقومات المادية لتنفيذ الأنشطة المعملية.

ع) توفير الدعم اللازم تجاه إعداد وتجميز ما يلزم لتفعيل التملييم الإكتروذي:

$$
\text { ويتتم ذلك من خلال: }
$$

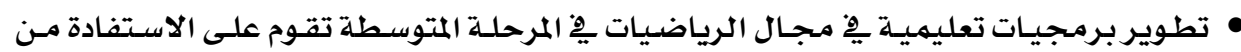

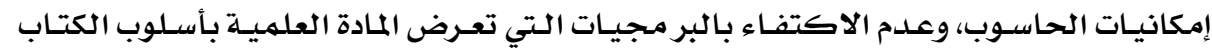

$$
\text { المدرسي ذي الإمكانيات المحلدودة. }
$$

• إنشـاء وتجهيـز مواقـع بريـد الكترونـي للمعلهـين على صـفحات الانترنت، حتى تيسـر عمليـة

$$
\text { التواصل مـع الطلبـة. }
$$

• إنشاء قواعد بيانات باللغة العربية للاستفادة منها ِِِ التعليهم. 


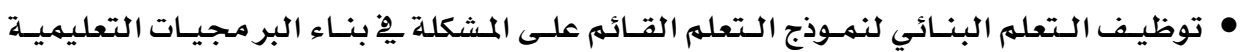 للمفاهيم الرياضيـة.}

\section{0) تفعيل الجانب التوعوي في العملية التعليمية:}

ويتهم ذلك من خلال الإيعاز للجهات المعنية يِّوزارة التربية والتعليم للقيام بالتالي: هقد الندوات للمعلمـين والمشرفين التربويـين للتعريف بنظام التقويه المستمـر وكيفيـة تطبيقـه بكفاءة.

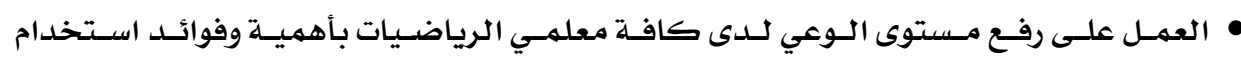

الحـاسوب يِ العمليـة التعليمية وذلك عن طريق إقامـة الندوات والمحاضـرات وتوزيـع النشرات.

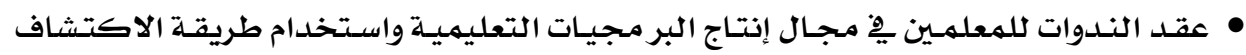
الموجه يُ تلدريس الرياضيات للهرحلة المتوسطة.

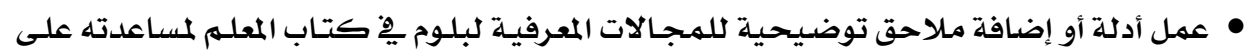

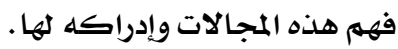
• إعداد دليل عملي يْ مهارات الاتصال اللفظي لمعلمي الرياضيات فِ المرحلة الابتدائية.

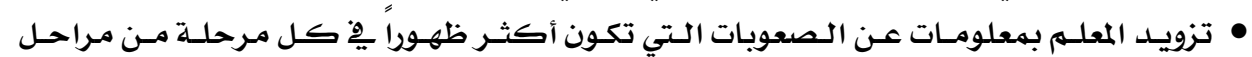
التعليم.

\section{1) توجيه الدعم الالازم لبعض الإدارات التخصصية بوزارة التربية والتعليه:}

وفيما يلي أهم هذه الإدارات ومـا ينبغي أن تقوم بـه من أدوار:

أ) الإدارة العامة للتطوير التربوي:

$$
\text { وذلك من حيث: }
$$

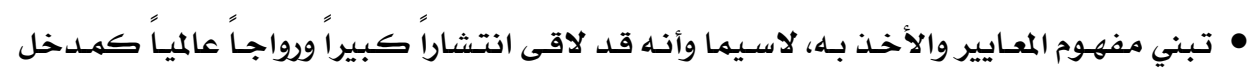

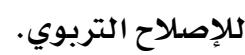

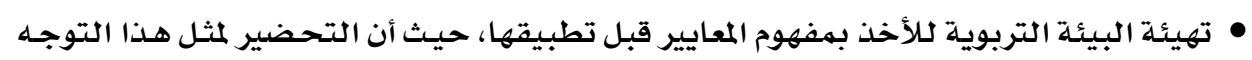
يعد مـن أبرز العوامل المسـاعدة على نجاحهـ وتحقيق أهدافهـ. • العمل على تصميهم وتتفيذ البر امـج التدريبية المشار إليها أعلاه.

$$
\text { ب) الإدارة العامة للتقويه: }
$$

• تحقيق الشمولية ِِ عملية التقويه المستهر ليشتمل على الجوانب السلوكية والأنشطة غير

الصفية والكشف عن ميول واتجاهات التتلاميذ.

• إيجاد لائحة تفسيريـة لمادة الرياضيات، توضتح آلية وأسـاليب ومهارسات تطبيق التقويه المستمـر.

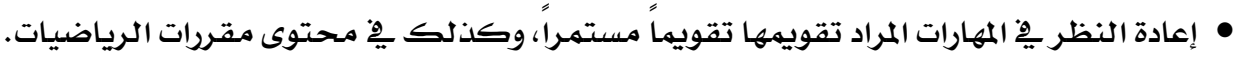


ج) الإثراف التربوي:

وذلـك مـن حيـث العهـل على تفعيـل أقسـام الرياضـيـات لـبعض الأسـاليب الإثـرافية مثـل

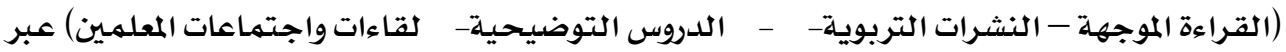

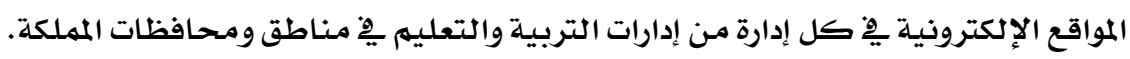

أما بالنسبة للتوصيات الخاصدة بالمعلهم فإنها تتركز على ثلاثة مجالات رئيسـة، هي:

$$
\text { ثانياً: }
$$

فسوف يتم تناو لها بالتفصيل على النحو التالي:

أولاً: دور المعلم في تطوير الذات:

يتحقق ذلك من خلال الالتحـاق بـالبر امـج التدريبيـة، لاسيما المشار إليها أعلاه، بالإضـافة

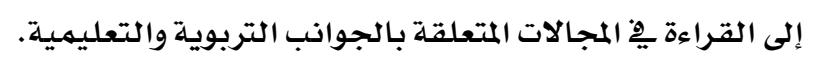

ثانياً: دور المعلم تجاه تخطيط الدروس:

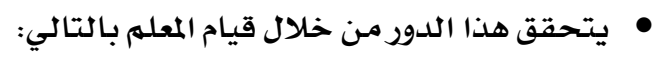

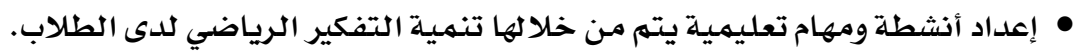

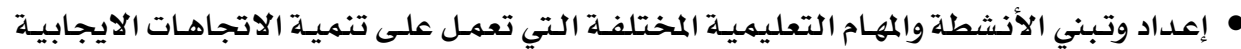

$$
\text { لدى الطلاب نحو الرياضيات المدرسية. }
$$

ثالثًا: دور المعلم تجاه تنفيذ الدروس:

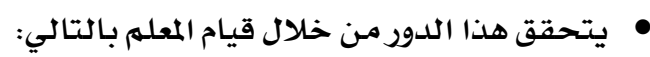

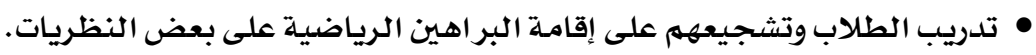

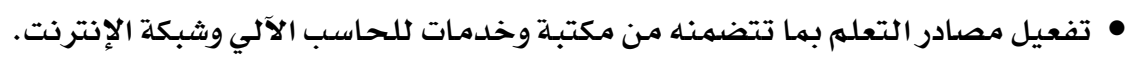

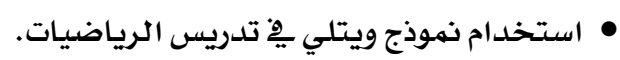

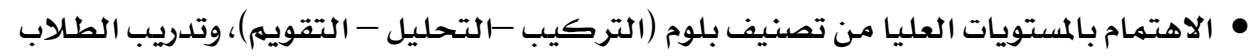

$$
\text { على ذلك. }
$$

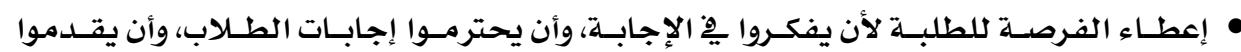

$$
\text { التغذية الرجعية الفورية. }
$$

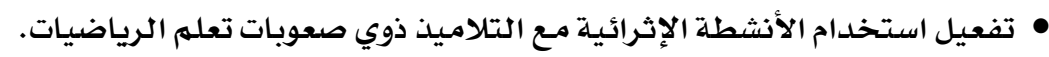

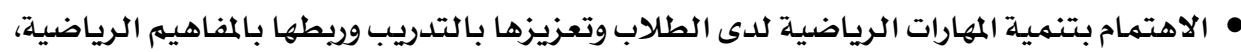

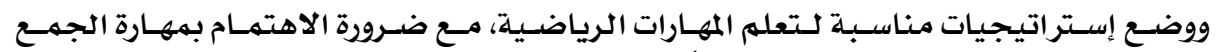

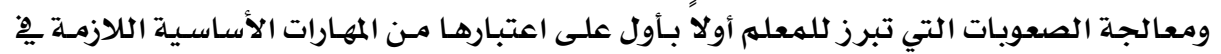




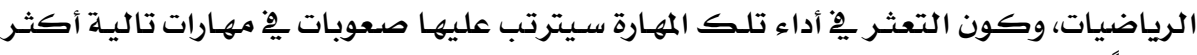

$$
\text { تعقيدا. }
$$

• تفعيل طريقة التـدريس باسـتخدام الألعـاب التعليميـة الإلكترونيـة ِِ تعليهم منـاهـج الرياضـيات

$$
\text { للتتلاميذ. }
$$

\section{البهة الثانية: وزارة التعليه العالي :}

ستشمل التوصيات وزارة التعليم العالي والجـامعات السعودية، بـالإضـافة إلى توصيات خاصسة

$$
\text { بأعضاء هيئة التدريس بتلك الجامعات. }
$$

وتتركز التوصيات الخاصسة بـالوزارة على مجـالين رئيسيسين هما :

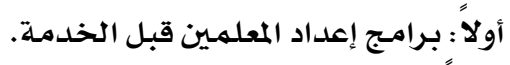

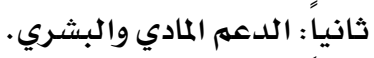

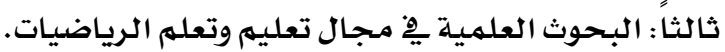

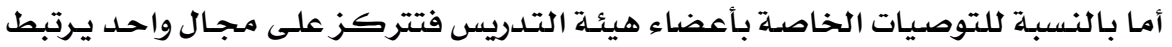

$$
\text { بإطساب الطلاب المهارات التدريسيـة اللازمـة. }
$$

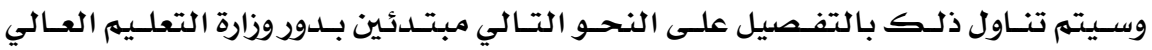

$$
\text { ومؤسساتها التعليميـة: وانية: }
$$

\section{أولاً: برامج إعداد المعلميز قبل الخدمة:}

وذلك من خلال التوصيـة بإدخال مقررات محسددة ِِّ بـرامـج إعداد المعلمـين بكليـات التربيـة،

وتضهـين بـرامـج إعداد المعلمـين بكليـات التربيـة لعدة موضوعات، بـالإضـافة إلى تطوير البر امـج مـن خـلال

$$
\text { وذلك على النحو التالي: }
$$

ا) إدخال المقررات التالية في برامج إعداد المعلمين بكليات التربية: • مقرر مستقل عن التقويم المستمـر يِّ الإعداد التربوي.

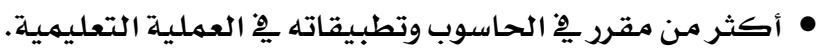
• مقرر لتثقيف الطالب المعلهم بهفاهيم الاتصال اللفظي ومهاراته.

ץ ب تضمين برامج إعداد المعلمين بكليات التربية للموضوعات التالية ضمن مقرراتها الدراسية:

$$
\begin{aligned}
& \text { • التعليه الإلكتروني يِّة تدريس الرياضيات. } \\
& \text { • مهارات التفكير الرياضي. } \\
& \text { • نموذج ويتلي. }
\end{aligned}
$$

• موضوعات تتعلق بالألعاب التعليهية الإلكترونية وتطبيقاتها التربوية. 
r قيام كليات التربية بالمملكة باتخاذ الإجراءات التالي:

• تدريب الطلاب المعلمـين على استخدام طرق التدريس المعتمدة على التعليم الإلكتروني.

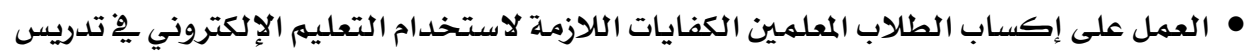

$$
\text { الرياضيات. }
$$

• إعادة النظر ِِّ كيفية إعداد معلمين الرياضيات للتعامل مـع صعوبات تعلهم الرياضيات.

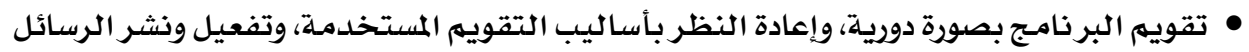

ثانياً: الدعم المادي والبشري:

$$
\text { وذلك من خلال توفير الدعم الدلازم لإجراء التالي: }
$$

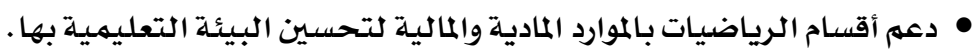

• تنمية قدرات أعضاء هيئة التدريس المهنية والعلميلة.

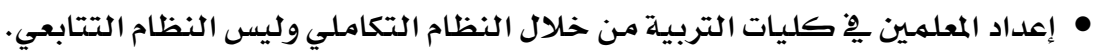

ثاثثاً: فيما يتعلق بالبحوث التربوية المعنية بالرياضيات:

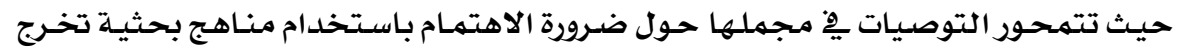

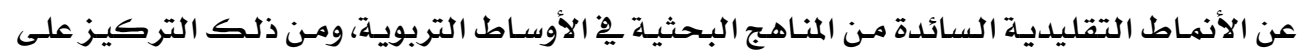

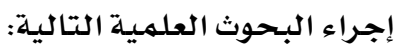

• البحوث الأسـاسية، والبحوث الإجرائية (بحوث الفعل)، والبحوث النواءية البحية بكافة أنواعها.

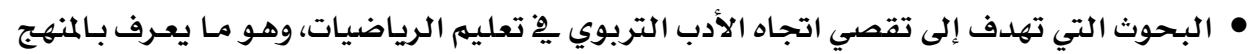
البيبليومتري (الإحصاء الوثائقي) (Bibliometrics).

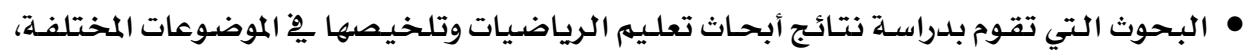

$$
\text { والتي تعتمد عادة على المنهج المستحي أو التحليلي. }
$$

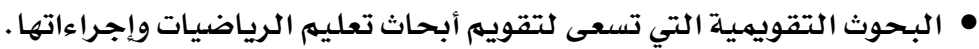

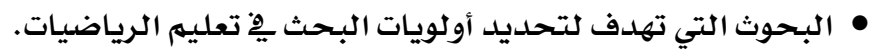

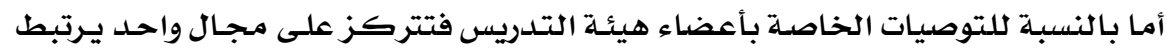

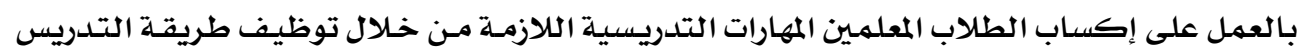

\section{البهة الثالثة: المرأسسة العامهة للتعليم الفني والتدريب المهني:}

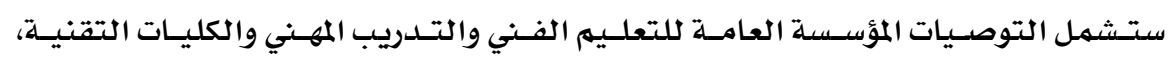

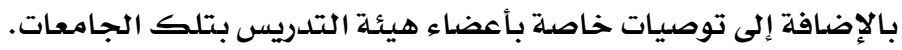
وسيتهم تناول ذلك على النحو التالي مبتدئين بدور المؤسسة والكليات التقنية: 


$$
\text { ينبغي على إدارات هذه الكليات أن: }
$$

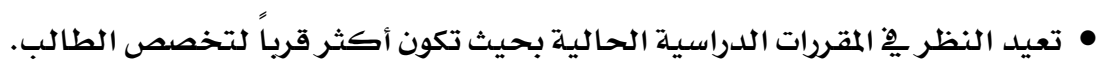

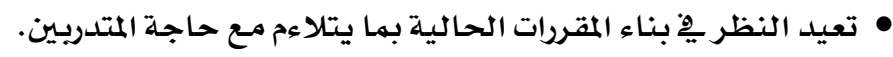

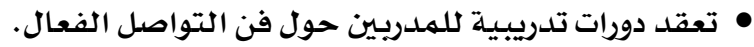

ثانياً : الأساتذة بالكليات التقنية:

• الالتحاق بلدورات تدريبية حول فن التواصل الفعال.

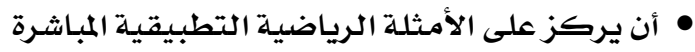

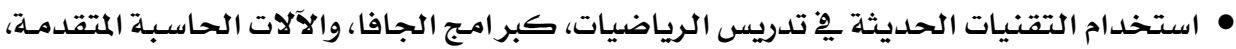

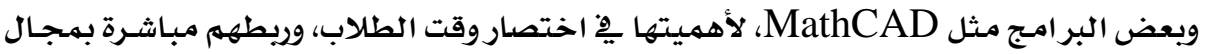

تخصصهم.

• تفعيل طـرق تـدريس مختلفـة خـلال تـدريس المقـررات، والعمـل على إثـراك المتـدرب يِّ العمليـة

التعليمية.

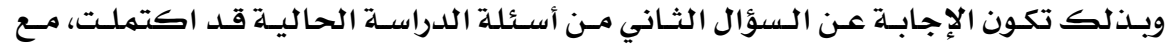

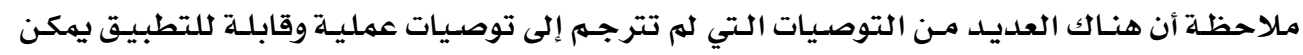

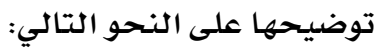

\section{التوصيات التي لم تثرجم إلى توصيات عملية:}

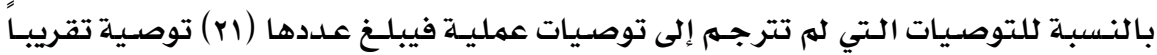

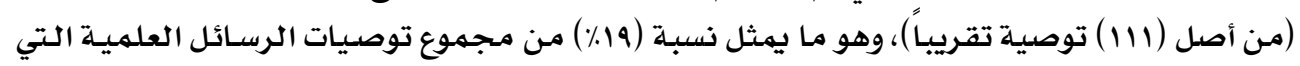

$$
\text { مثلت مجتمـع الدراسـة وعينتها. }
$$

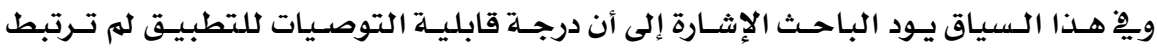

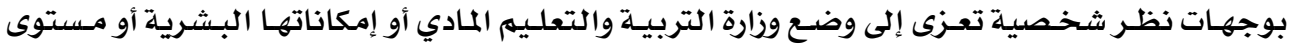

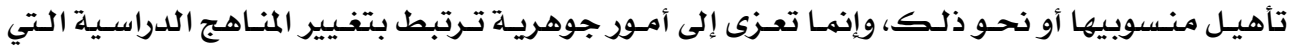

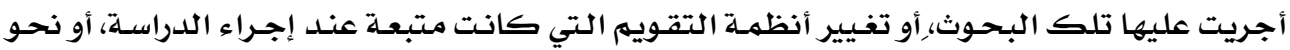

$$
\text { ذلك من أمور جوهريـة. }
$$

وعليه فقد تركزت تلك التوصيات التي لم تترجهم إلى توصيات عملية على ما يلي: تماتي 1) توصيات تركزت على مناهج الرياضيات السابقة (بما تتضمنه من كتب مقررة وأدلـة معلمـين

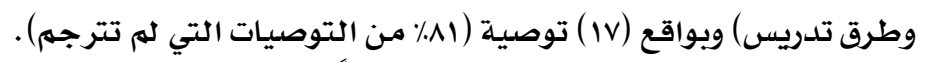

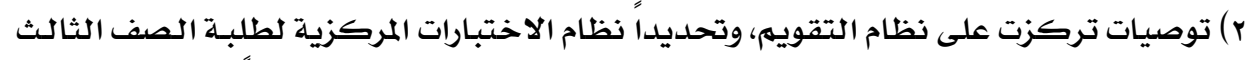

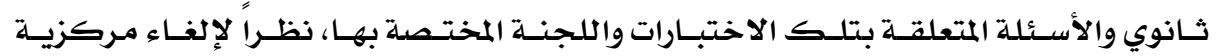


الاختبارات قبل عدة سنوات.وكان ذلك بواقع توصيتين اثنتين (،,9٪ من أصل التوصيات التي

لم تمترجم).

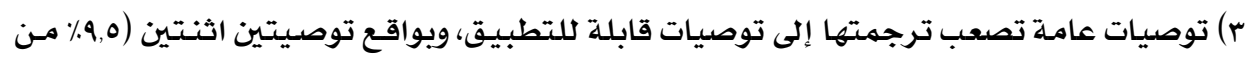
أصل التوصيات التي لم تترجم).

ثالثًا: تتائج الإجابة عن السؤال الثالث:

كان السؤال الثالث من أسئلة الدراسة على النحو التالي:

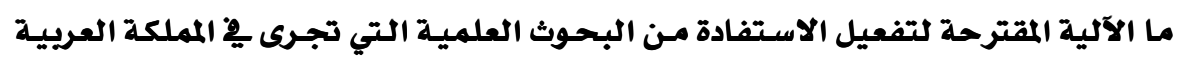

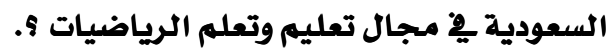

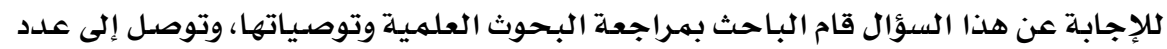

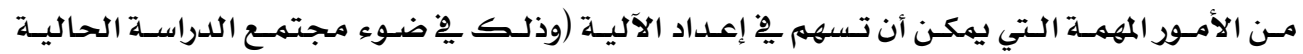

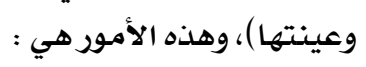

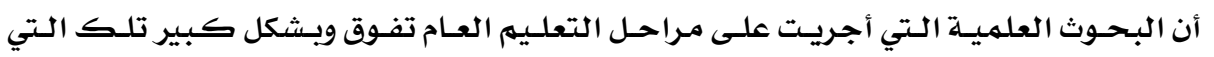

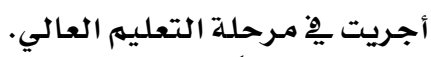

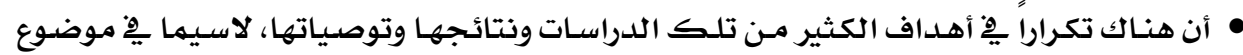

$$
\text { التعليم الإلكتروني. }
$$

• أن هناك جهودا كبيرة قد بذلت يِّو إعداد دراسات ريما تكون الاستفادة مـن نتائجها وتوصياتها

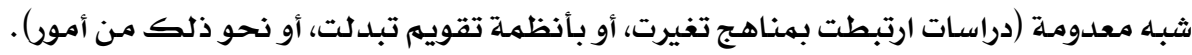

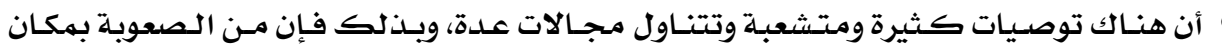

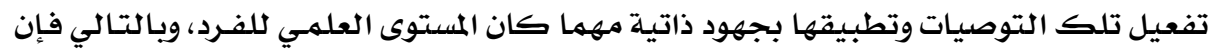

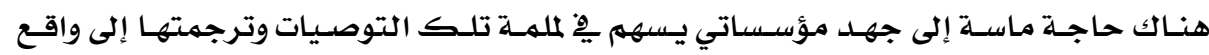

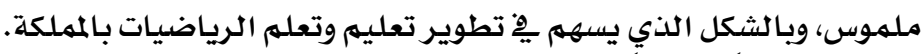

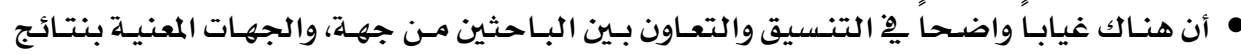

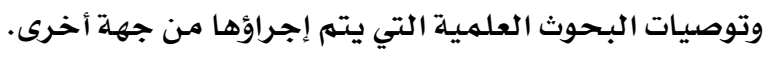

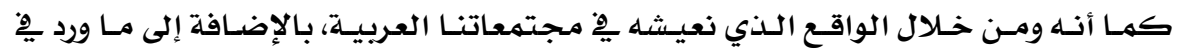

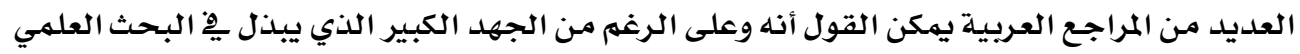

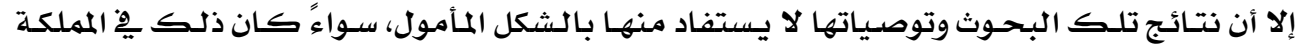

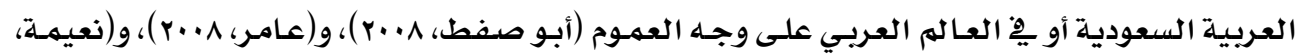

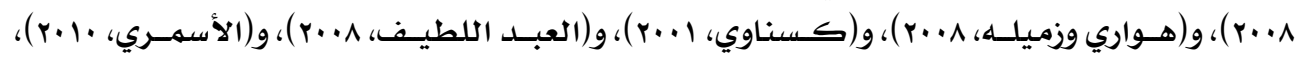

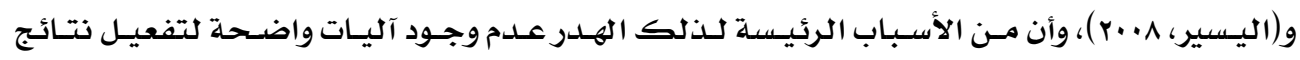

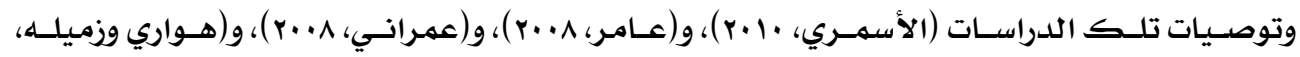




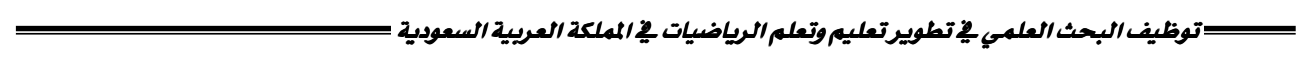 وهِّ ضوء ما سبق يمكن إعداد الآلية المقترحة على النحو التالي :}

\section{الآلية الاقتزحة: \\ تتمثل الآلية المقترحة يِّ التالي:}

أولاً: تحلديد الجهة الرئيسة المشرفة على البحث العلمي في مجال تعليم وتعلم الرياضيات بالمملكة:

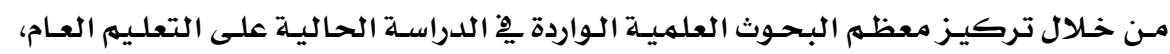

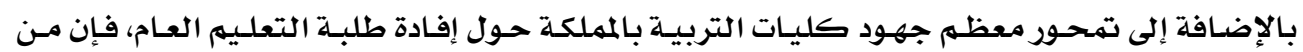

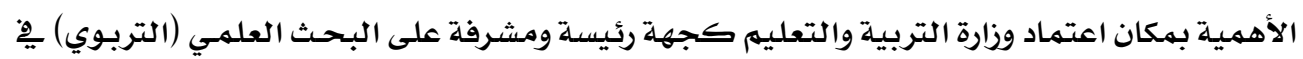

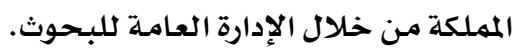

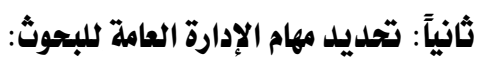

$$
\text { وذلك عن طريق: }
$$

) (عمل رابط خاص على موقع وزارة التربية والتعليم :

على أن يتضمن الرابط الرئيس (r) روابط فرعية هي:

أ) رابط استقبال البحوث التربوية المقترحة من قبل التربويين يِ الميدان:

بحيث يقتصر الهدف من هذا الرابط على استقبال عناوين مقترحة لبحوث علميـة مـن قبل

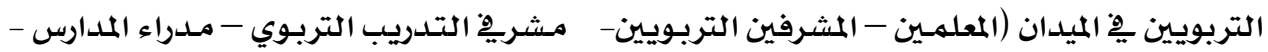

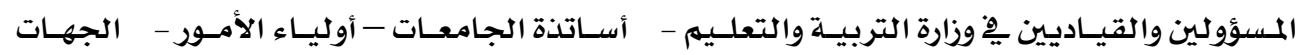

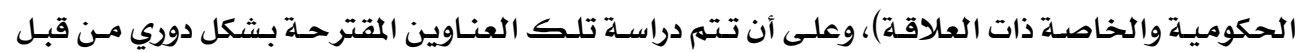

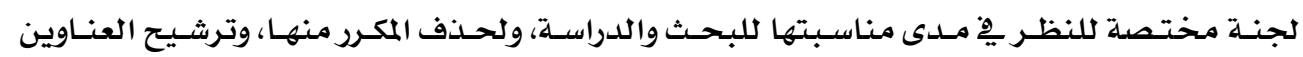
النهائية المناسبة للعمل محتهلة للنفيها. ب) رابط العناوين النهائية المقترحة للبحوث العبله لعلمية:

بعـد اسـقبال العنـاوين المقترحسة على الرابط الخـاص ومسن ثم دراستها وتنقيحهـا مـن قبـل

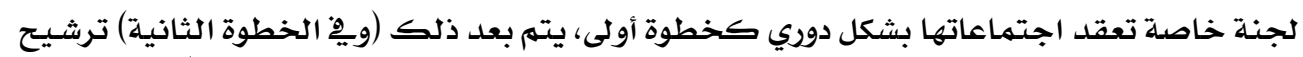

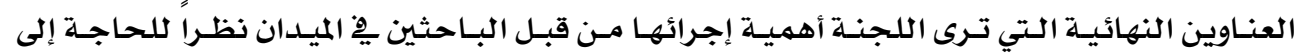

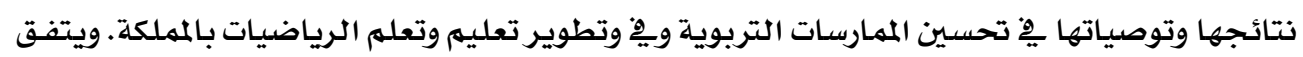

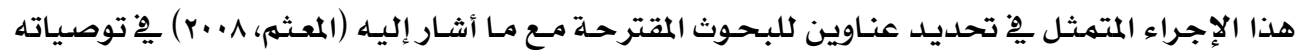

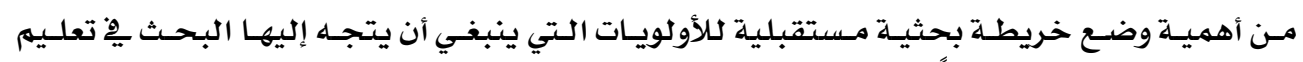

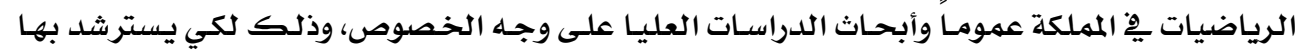

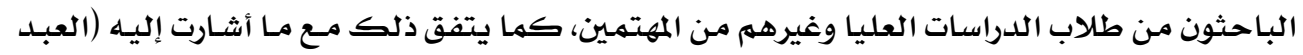

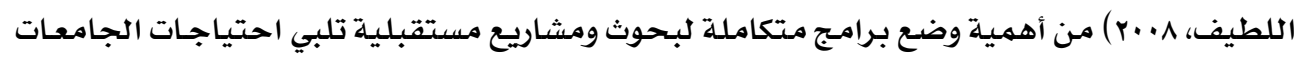

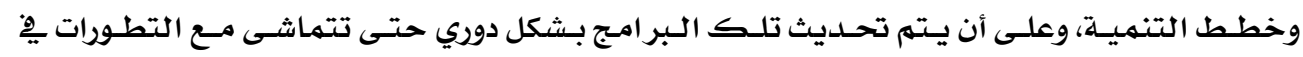
مختلف المجالات. 
وبعـد ذلك يهــن للبـاحثين اختيـار أحسد تلـك العنـاوين المرثـحة للعهـل عليها وفق نهـوذج

خاص، وعليـه ينوه أن الموضوع تحت الدراسلة.

كهـا أن مـن الأهميـة بهكـان تـوفير الإدارة العامــة للبـحـوث لـدعم مـادي ومعنـوي منـاسـبـ

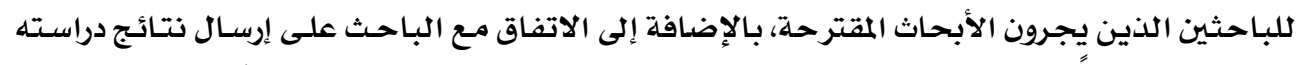

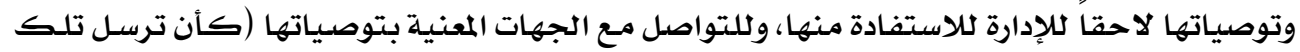
النتائج والتوصيات إلى التدريب التربوي لترجمتها إلى برامـج تدريبية).

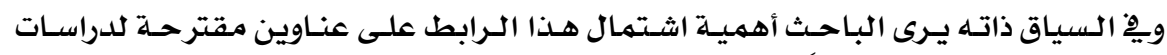

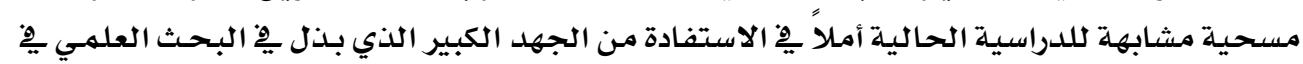

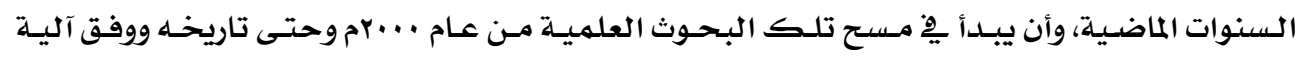

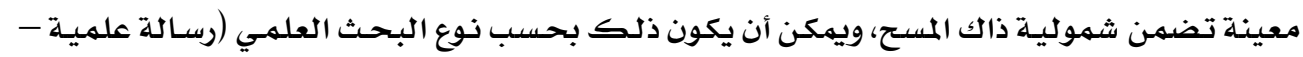

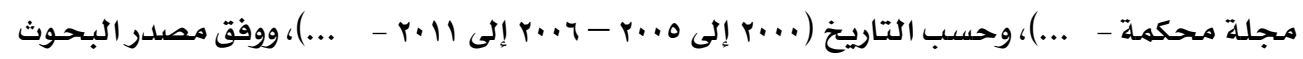

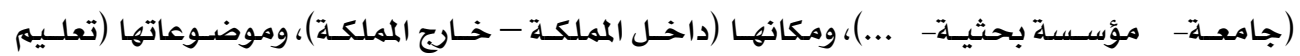

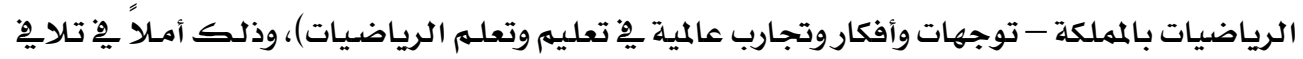

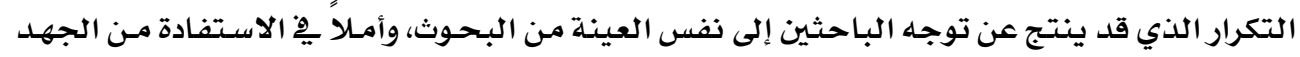
العلهي الكبير الذي بـل من قبل البـاحثين والمهتمهين. ج) رابط نتائج البحوث التربوية الخاصـة بتعليهم وتعلم الرياضيات:

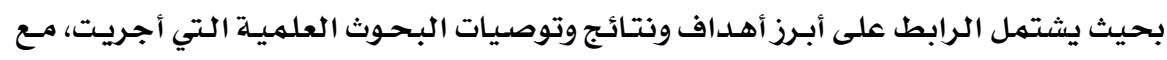
ترجمتها إلى توصيات تطبيقيـة.

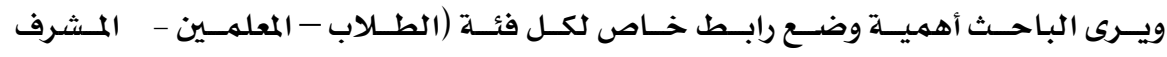

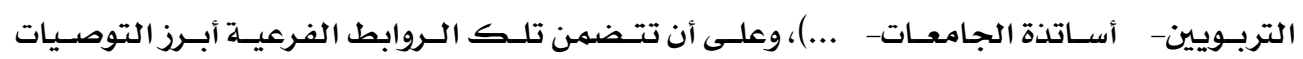

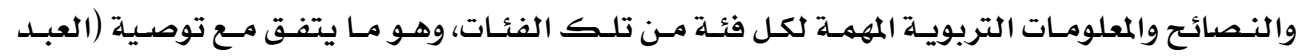

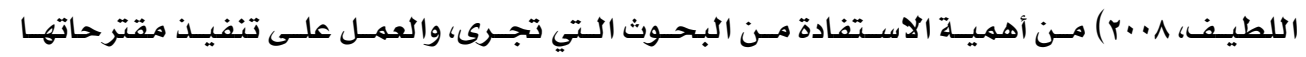

وتوصسياتها .

\section{r) تولي الإدارة العامة للبحوث عملية التنسيق مع الجهات ذات العلاقة داخل الوزارة:}

وأبرزها الإدارة العامـة للتطوير التربوي، والإدارة العامـة للتدريب والابتعـاث، وذلك مـن أجل

ترجمـة توصيات تلك البحوث العلميـة إلى برامـج تدريبية ونشرات توعوية وندوات علميـة .

r) تولي الإدارة العامة للبحوث عملية التنسيق مع الجهات ذات العلاقة خارج الوزارة:

$$
\text { وأ والجن أبرز تلك الجهات الجهات السعودية: }
$$




$$
\text { • التتسسيق مـع الجـامعات لدعم البحث العلهي التربوي : }
$$

وذلك مـن خـلال عدة إجـراءات، منهـا تشجيـع الأسـاتذة الجـامعيـين وطلبـة الدراسـات العليـا

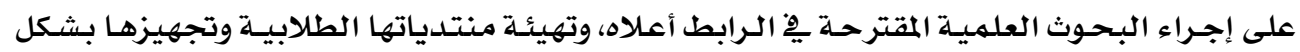
وجذاب وبما يسهم فِ إيجاد طريقة فعالـة للتواصل مـع البـاحثين فِ الميـان*، وهـو مـا يعزى عهـي

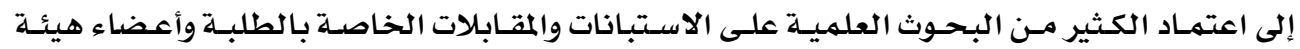

$$
\text { التدريس على حد سواء. }
$$

مـع أهميـة تشجيـ أعضاء هيئة التدريس والطلبة على التعاون مـع البـاحثين من خلال بعض

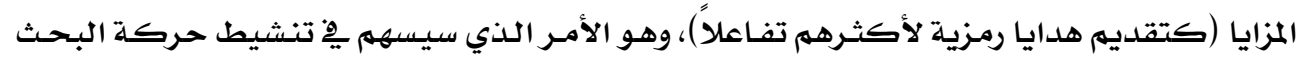

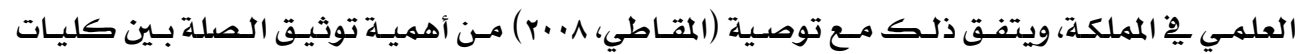
التربيـة بالجـامعـات ومـراكـز التطـوير التربـوي يِ وزارة التربيـة والتعلـيم لتحقيـق الأهـداف التربويـة

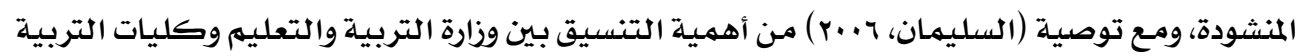
بالمملكة بها يسهم يف تحسين العملية التعليميـة.

• تشجيـع الجامعات على تفعيل مصادر المعرفة وإتاحتها للباحثين عبر الشبكة الإنترنت:

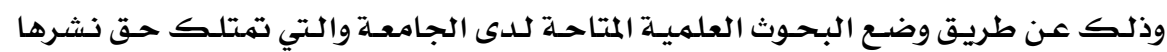
والتصرف فيهـا (كاكرسـائل العلميـة الـصادرة عنهـا) على شـبكة الإنترنت ليسسهل الحـصول عليهـا والاسـتفادة منهـا، ويتفق ذلك مـع توصسية (Engelbrecht \& Harding, 2005)مـن أهميـة تـوفير الأدبيات والمراجع المتعلقة بالرياضيات للمهتهمين بتوفيرها على شبكة الانترنت، نظراً لأهميـة الشبكة

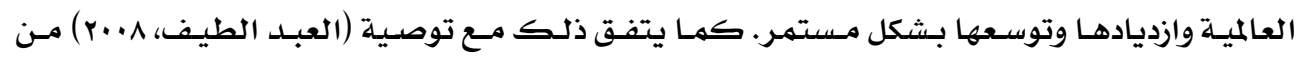
أهميـة التعاون والتتسيق مـع الجهات ذات العلاقة لتوفير المصادر العلمية لخدمة الباحثين.

$$
\text { ب) المراكز البحثية: }
$$

حيـث ينبغـي تشجيـع المراكز البـحثيـة على تفعيـل مـصـادر المعرفة وإتاحتهـا للبـاحثين عبر

الشبكة الإنترنت لتسهيل الحصول عليها والاستفادة منها.

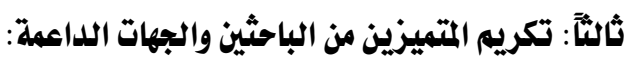

بحيـث تحصـي الإدارة العـامـة للبـحـوث سـنوياً أبـرز الانجـازات البـحثيـة الفرديـة وأبـرز الجهات

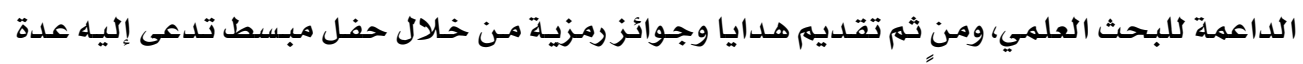
شخصيات اعتبـارية بـارزة، أملاً أن يسهم ذلك فِّ تفعيل حركة البحث العلهي التطبيقي التربوي وبها يسهم يه عملية تطوير تعليهم وتعلهم الرياضيات بالمملكة.

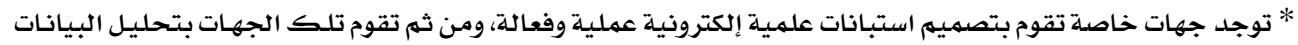

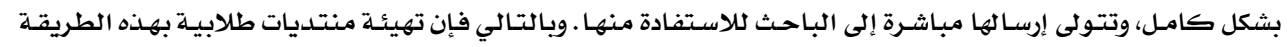

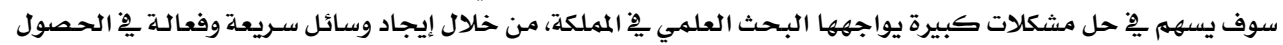
على استجابات عينة الدراسة. 


\section{التوصيات:}

مِِّ ضوء نتائج الدراسة يوصي الباحث بما يلي:

أولاً: بالنسبة لوزارة التربية والتعليه:

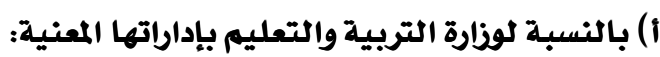

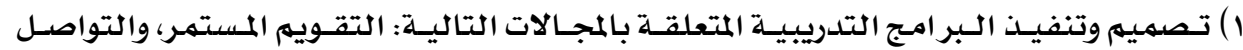

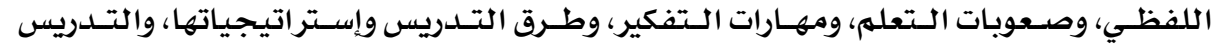

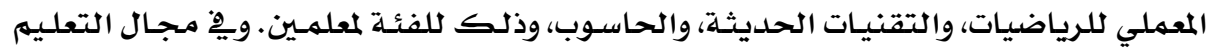

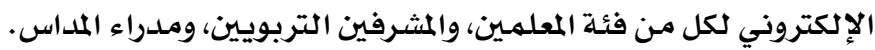

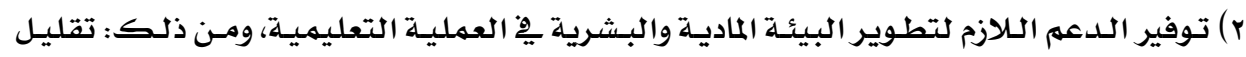

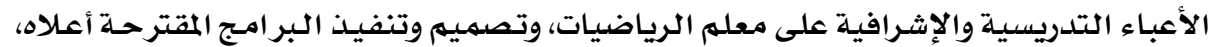

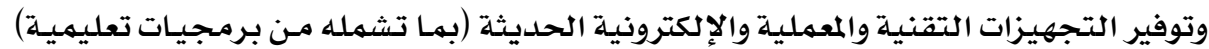

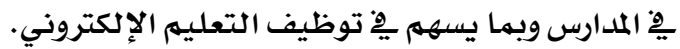

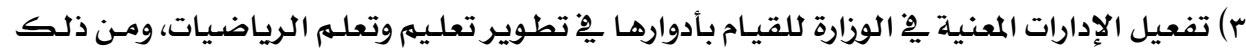

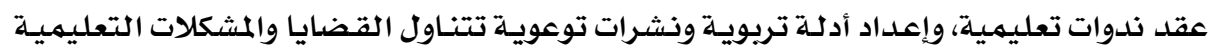

$$
\text { ذات العلاقة. }
$$

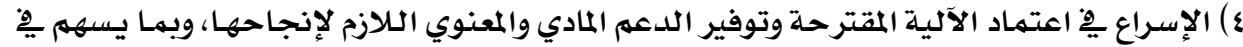

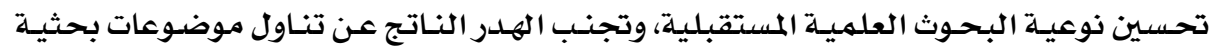
مكررة أو غير مجدينة. ب) بالنسبة للمعلمين: 1) تطوير الذات من خلال القراءات المستمـرة يْ مجال التخصص، وِِّ المجالين التربوي والمهني.

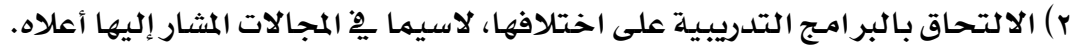

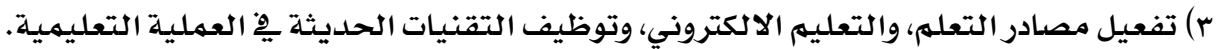

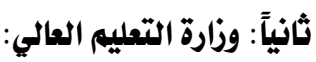

\section{أ) بالنسبة لوزارة التعليم العالي بمؤسساتها التعليمية:}

1) تطوير برامج إعداد المعلمين بكليات التربية من خلال إدخال مقررات جديدة تتنـاول موضوعات

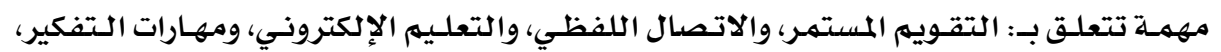

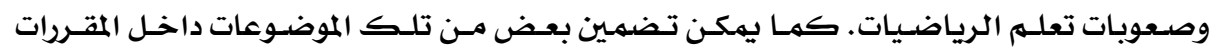

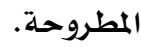

r) إخضاع برامـج إعداد المعلم بكليات التربية للتقويم والتطوير المستمـرين.

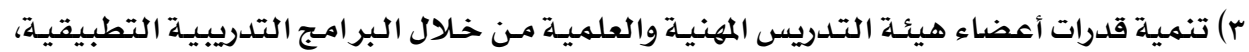
ومن خلال دعم البحوث النوعية والتطبيقية. 
ع) تقديم مسـاعدة أكبر للبـاحثين من خلال تهيئـة منتديات النقـاش الطلابيـة الجامعيـة بالشكل

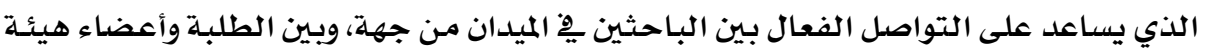

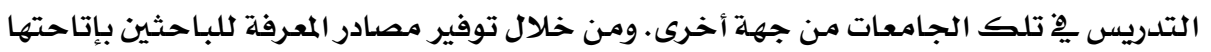

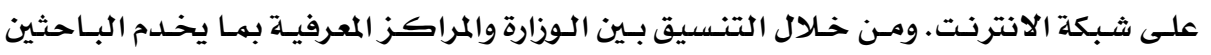
ويتيح مصادر المعرفة لهم. ب) بالنسبة لأعضاء هيئة التدريس:

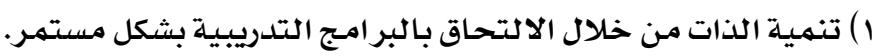

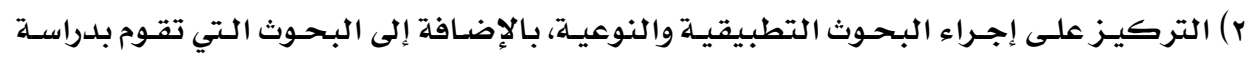

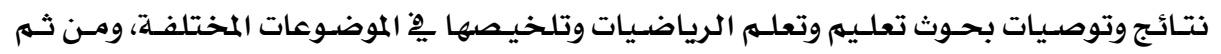

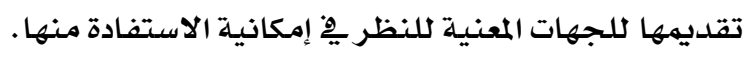
ثالثًا: المؤسسة العامة للتعليم الفني والتدريب المهني: أ) بالنسبة للكليات التقنية على وجه الخصوص: 1) تطوير مقررات الرياضيات لتكون أكثر قدرة على تحقيق أهدافها .

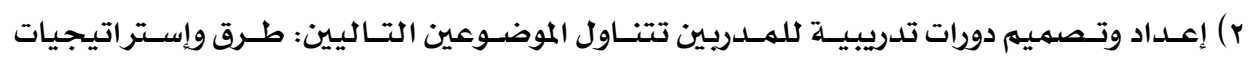

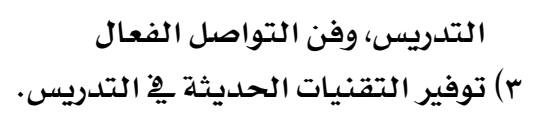
ب) بالنسبة لأعضاء هيئة التدريس بِ الكليات التقنية:

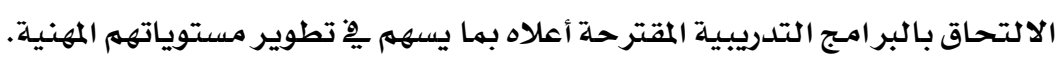
رابعاً: بالنسبة للباحثين وطلبة الدراسات العليا: ( ) تجنب الهدر الناتج عن إجراء بحوث علمية غير مفيدة من خلال دراسلة موضوع البحث وإمكانية

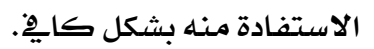

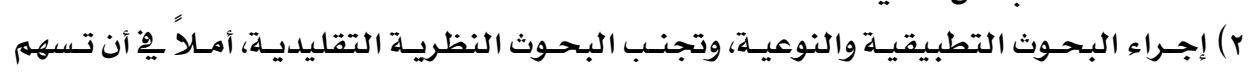

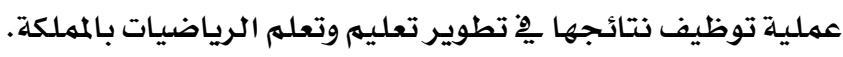

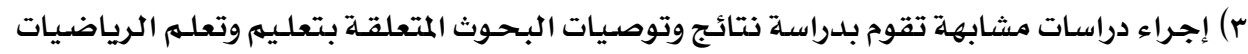

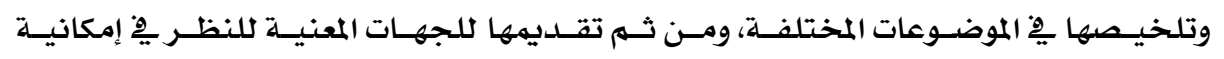

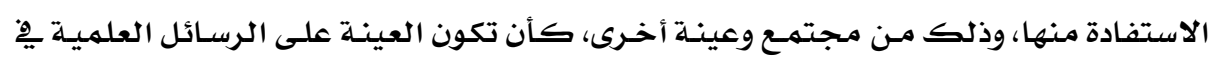

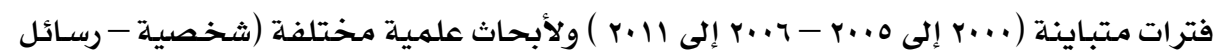

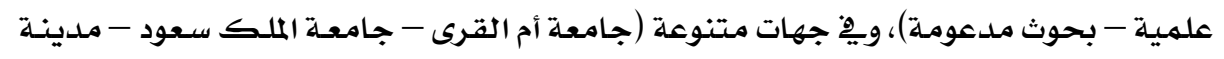

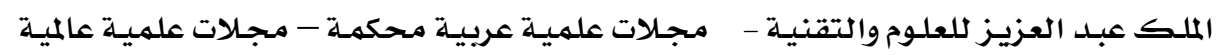




\section{المراجع: \\ المراجع العربية:}

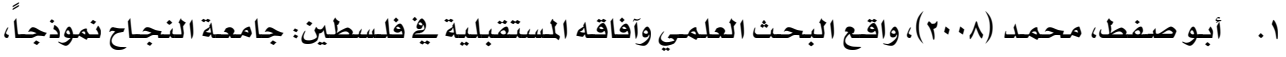

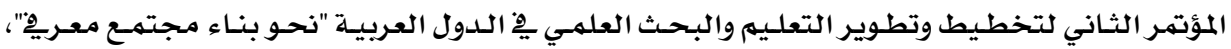

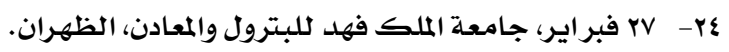

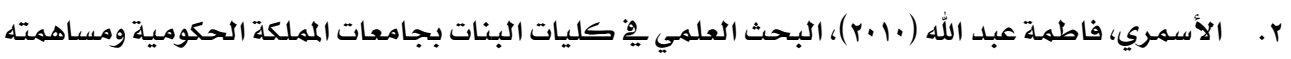

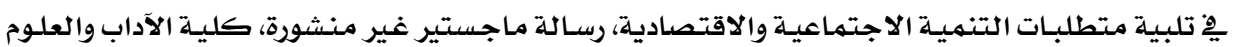
الإدارية، جامعة أم القرى.

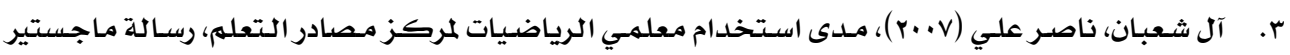

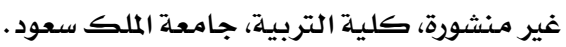

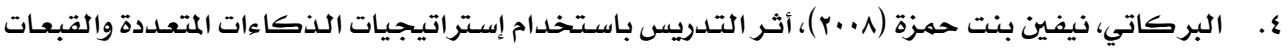

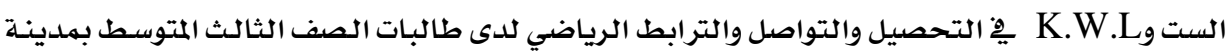

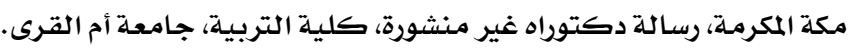

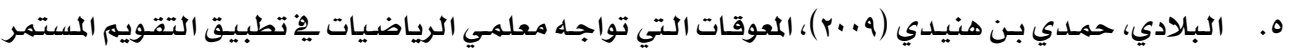

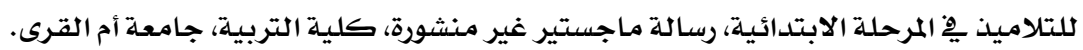

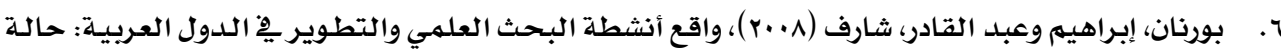

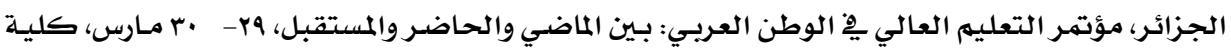
التربية، جامعة قطر، الدوحة.

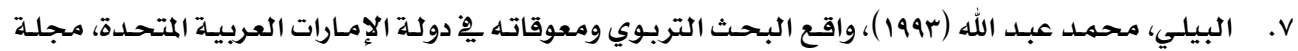

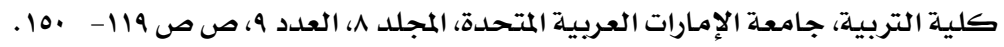

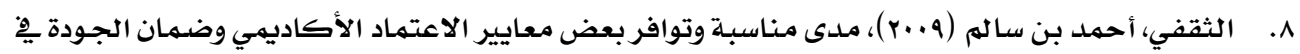

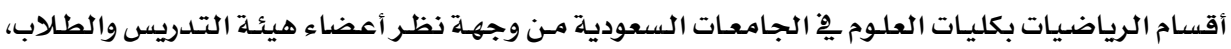

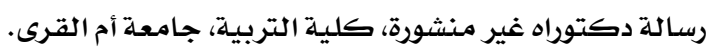

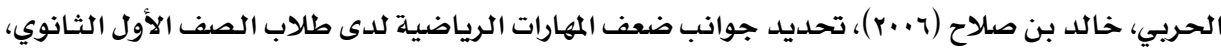

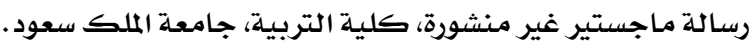

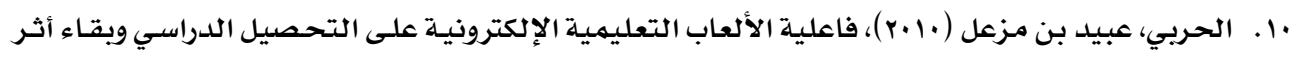

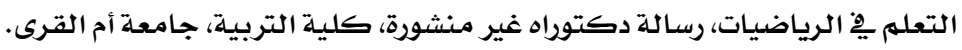

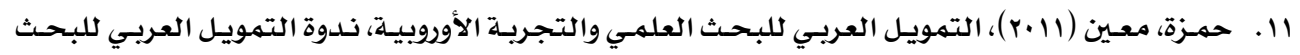
،http://www.arabschool.org.sy/Celebration/Dr.Mueen\%20Hamzeh.doc العلهـ-

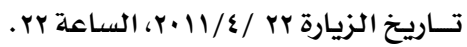

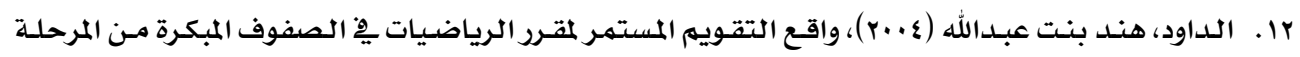
الابتدائية للبنات، رسالة ماجستير غير منشورة، كلية التربية، جامعة الملك سعود. 


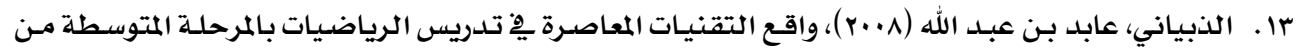

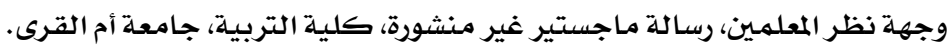

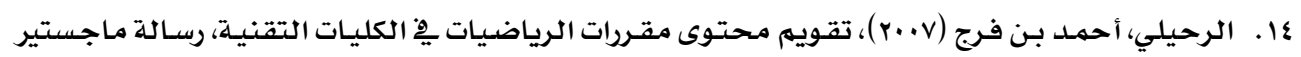

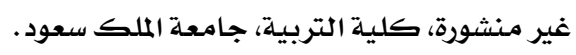

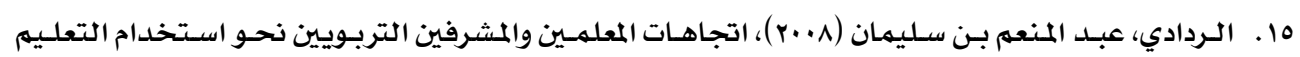

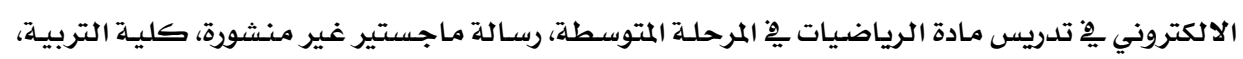
جامعة أم القرى.

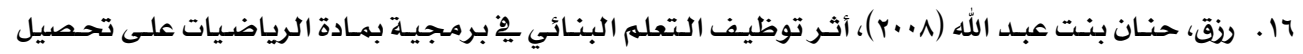

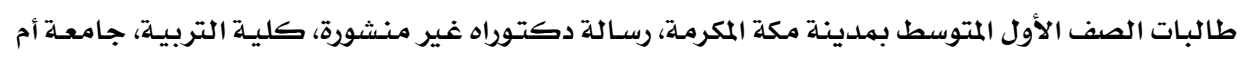
القرى.

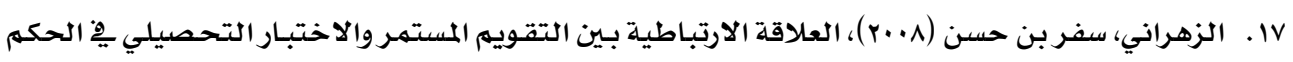

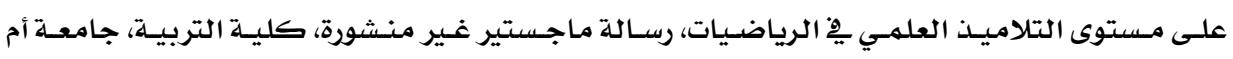
القرى.

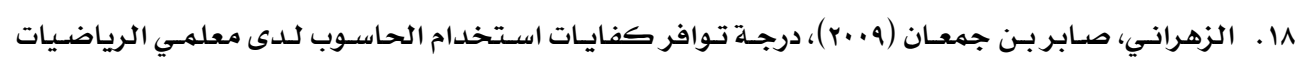

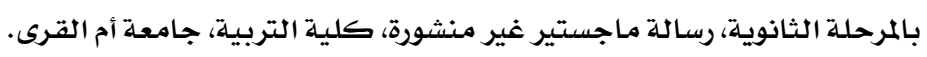

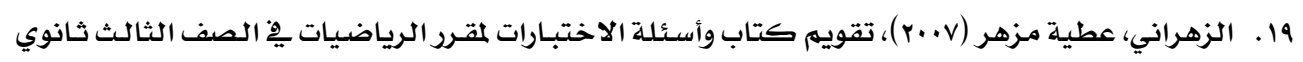

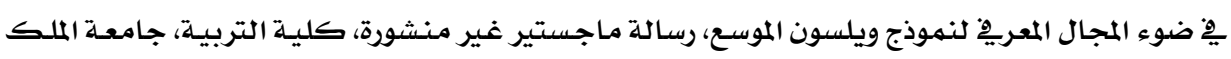

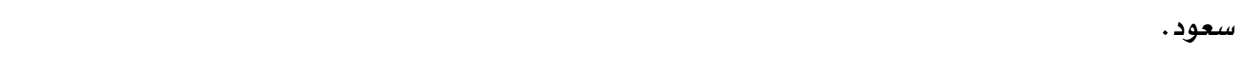

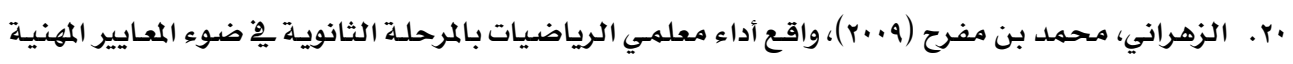

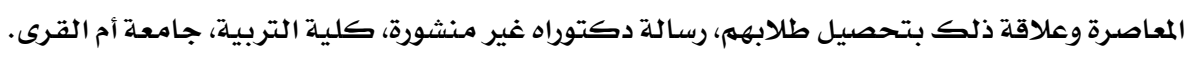

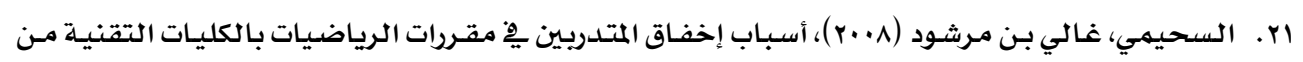

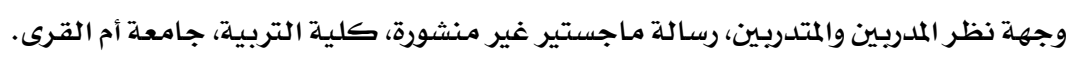

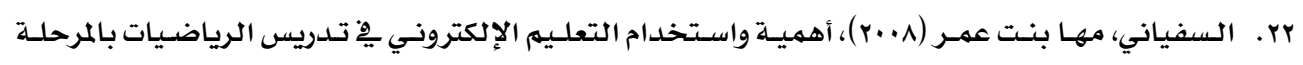

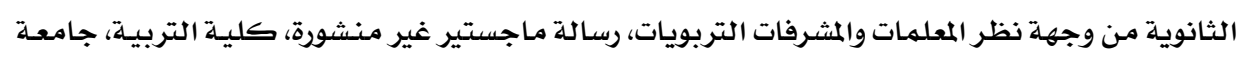

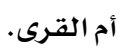

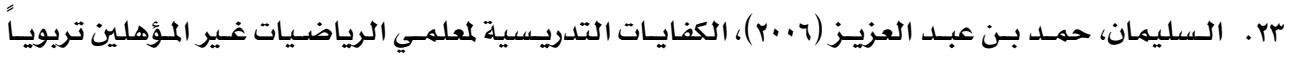

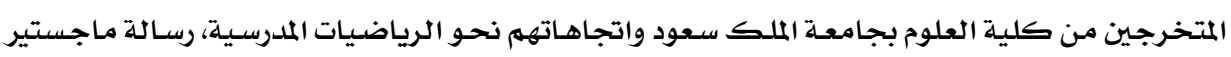

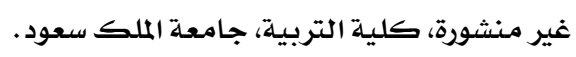

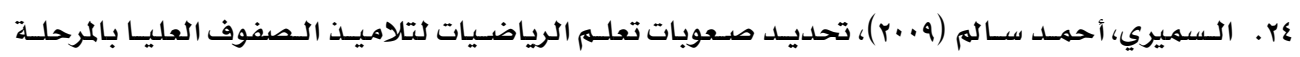

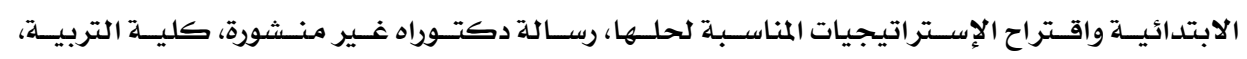
جامعة أم القرى. 


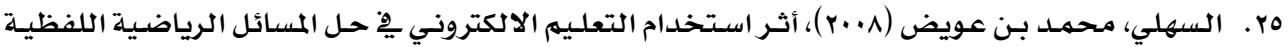
على التحـصيل الدراسـي لطـلاب الصف الثـاني المتوسـط، رسـالة مـاجستير غـير منـشورة، كليـة التربيـة، جامعة أم القرى.

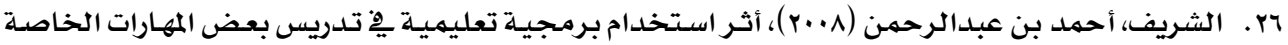

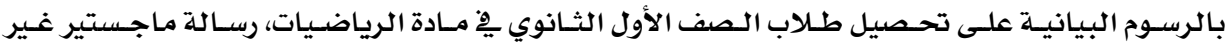
منشورة، كلية التربية، جامعة أم القرى.

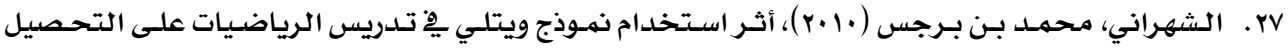
الدراسـي والاتجــاه نحوهـا لـدى تلاميـذ الـصف السـادس الابتــائي، رسـالة دكتـوراه غـير منـشورة، كليـة التربية، جامعة أم القرى.

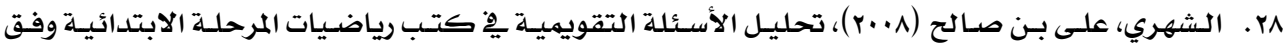
المستويات المعرفية لبلوم، رسالة ماجستير غير منشورة، كلية التربية، جامعة أم القرى.

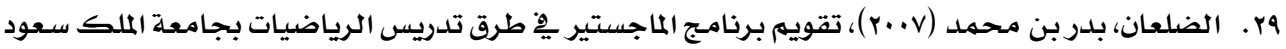

من وجهة نظر الدارسين والخريجين، رسالة ماجستير غير منشورة، كلية التربية، جامعة الملك سعود.

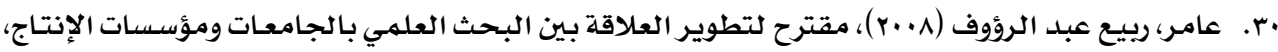

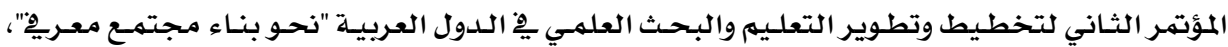
צ - - TV فبر اير، جامعة الملك فهد للبترول والمعادن، الظهران.

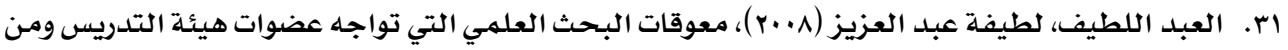

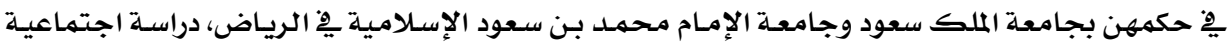
وصفية تحليلية، مـركز بحوث كلية الآداب، كلية الآداب، جامعة الملك سعود.

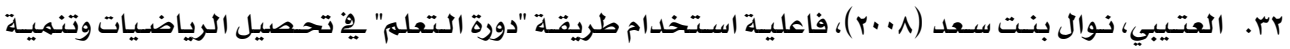

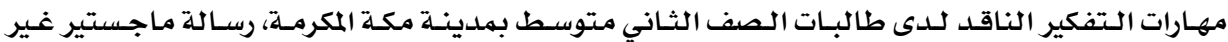
منشورة، كلية التربية، جامعة أم القرى.

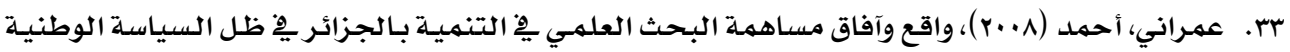
الجديدة للبـحث العلمي والتطوير التكنولوجي، المؤتمـر الثاني لتخطيط وتطوير التعليهم والبحث العلهـي

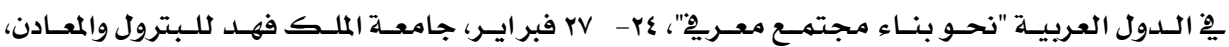
الظهران.

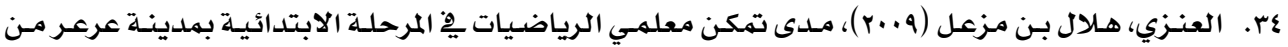
مهارات الاتصال اللفظي، رسالة ماجستير غير منشورة، كلية التربية، جامعة أم القرى.

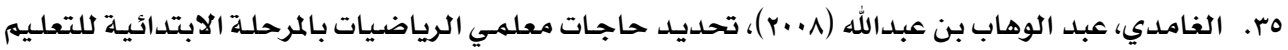
الإلكتروني، رسالة ماجستير غير منشورة، كلية التربية، جامعة أم القرى.

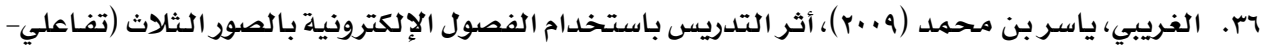
تعاوني- تكاملي) على تحصيل تلاميـ الصف الخـامس الابتـدائي يِّ مـادة الرياضـيات، رسـالة مـاجستير غير منشورة، كلية التربية، جامعة أم القرى. 


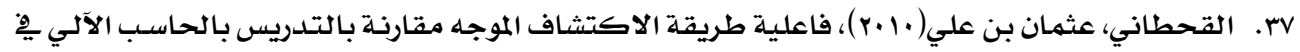

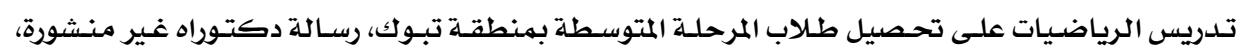
كلية التربية، جامعة أم القرى.

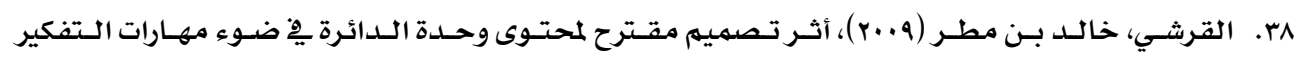

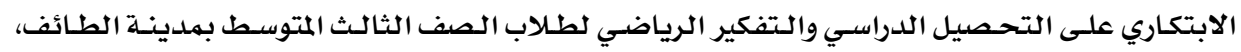

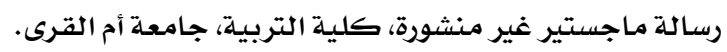

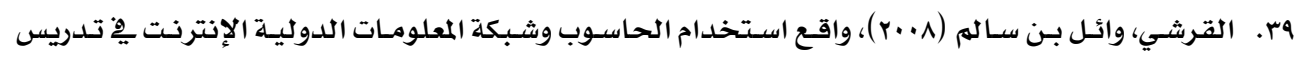

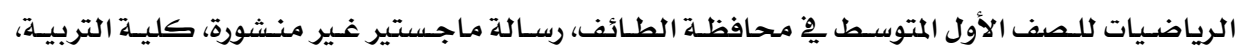
جامعة أم القرى.

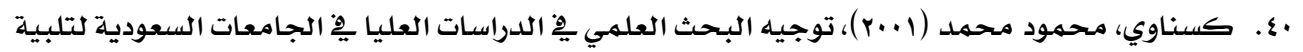

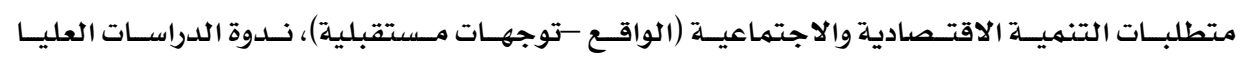

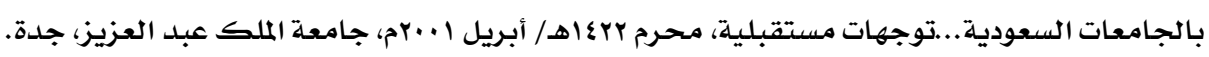

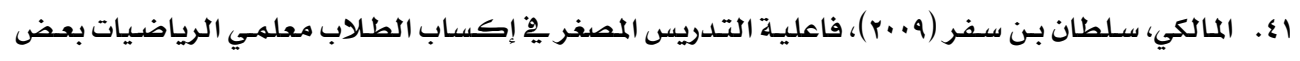

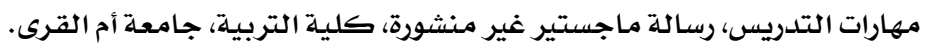

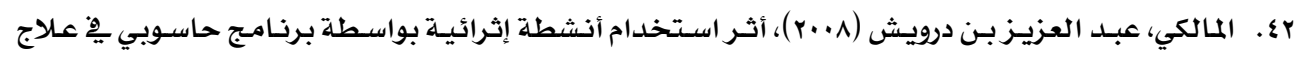

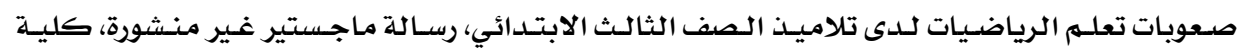

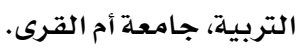

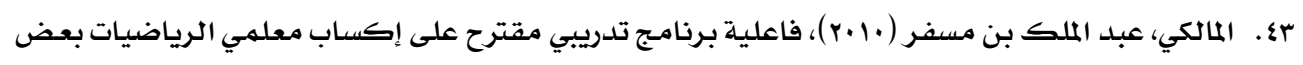

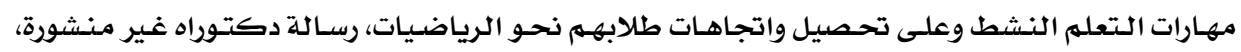
كلية التربية، جامعة أم القرى.

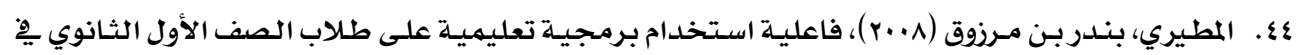

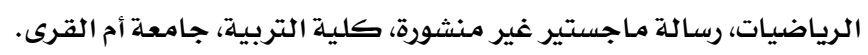

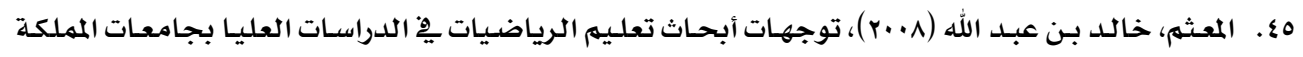

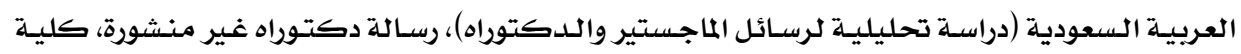

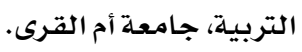

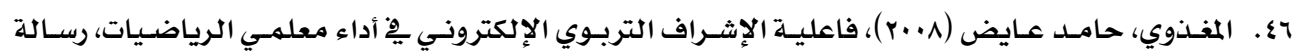

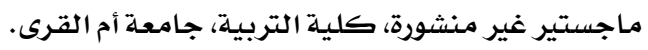

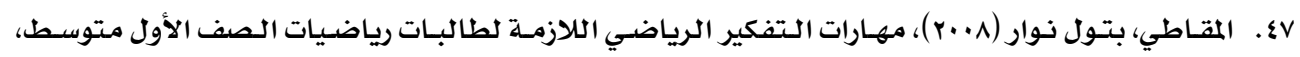

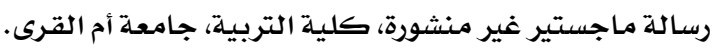

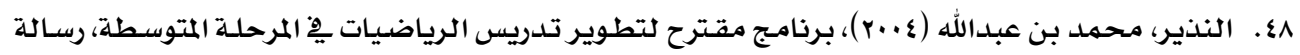

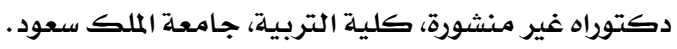




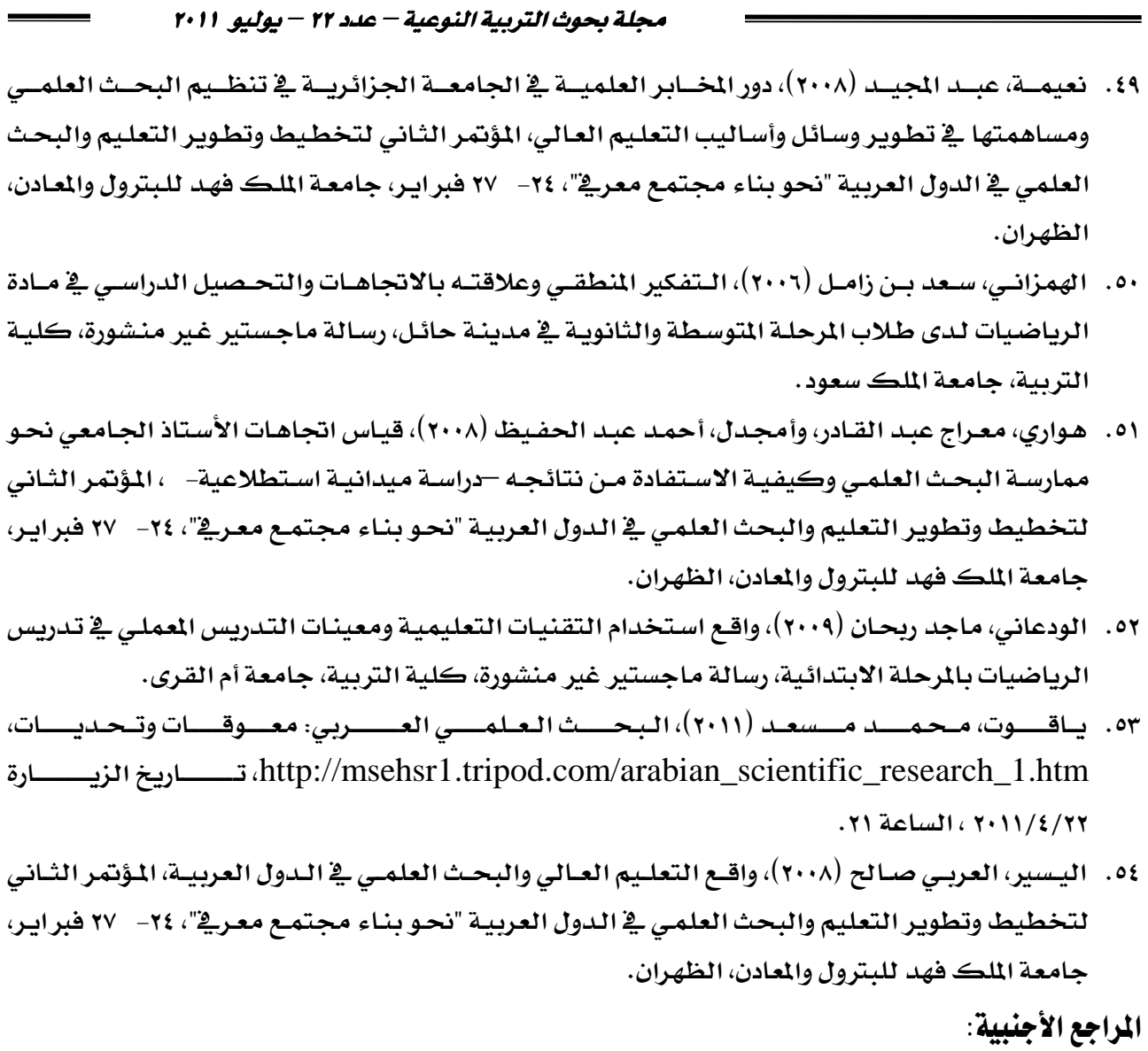

55. bin Tareef, Atif.(2009), Scientific Research in Jordanian Higher Education Institutions: An Evaluation of the Status and Obstacles. Journal of Instructional Psychology; Jun2009, Vol. 36 Issue 2, p158-168,11P.

56. Brown, D. \& Yürekli, O.(2007). Undergraduate research in mathematics as a curricular option. International Journal of Mathematical Education in Science \& Technology; 2007, Vol. 38 Issue 5, p571-580, 10p.

57. Engelbrecht, Johann \& Harding, Ansie.(2005). Teaching Undergraduate Mathematics on the Internet. Educational Studies in Mathematics; 2005, Vol. 58 Issue 2, p235-252, 18p.

58. Gupta, Sat, and Others.(2006). Predictors of Student Success in Entry-Level Undergraduate Mathematics Courses. College Student Journal, 01463934, Mar2006, Vol. 40, Issue 1.

59. Lamanauskas, Vincentas \& Augiene, Dalia.(2009), Pupils' Scientific Research Activity Development in Comprehensive School: The Case of Lithuania .Journal of Baltic Science Education; 2009, Vol. 8 Issue 2, p97-109, 13p, 7 Charts. 
60. Longres, John F.\& Scanlon, Edward.(2001), Social Justice and The Research Curriculum. Journal of Social Work Education, 10437797, Fall2001, Vol. 37, Issue 3.

61. Matthews, Michael E.\& Seaman, Walter I.(2007). The Effects of Different Undergraduate Mathematics Courses on the Content Knowledge and Attitude towards Mathematics of Preservice Elementary Teachers. Issues in the Undergraduate Mathematics Preparation of School Teachers, v1 Jul 2007. 16 pp. (Peer Reviewed Journal).

62. Rotman, Sumner\& Messelaar, Thijs.(2005a). Centered on Teacher Training. Techniques: Connecting Education and Careers, v80 n6 p30-31 Sep 2005. 4 pp.

63. Rotman, Sumner\& Messelaar, Thijs.(2005b). A Preliminary Look at Systems of Evaluating Teachers in Institutions of Higher Education and at Evaluation Methods. Chinese Education \& Society; Sep/Oct2005, Vol. 38 Issue 5, p48-60, $13 \mathrm{p}$.

64. Smith, Richard, and Others.(2006). Predicting Success for Actuarial Students in Undergraduate Mathematics Courses. College Student Journal, 01463934, Mar2005, Vol. 39, Issue 1.

65. TIMSS.(2005), IEA's TIMSS 2003 International Report on Achievement in the Mathematics Cognitive Domains. TIMSS \& PIRLS International Study Center, Boston College, 2005.

66. TIMSS.(2009), TIMSS 2007 International Mathematics Report (Findings from IEA's Trends in International Mathematics and Science Study at the Fourth and Eighth Grade). TIMSS \& PIRLS International Study Center, Boston College, August 2009.

67. Weinstein, Lawrence \& Laverghetta, Antonio.(2009). Does Experience in College Mathematics Courses Affect Elementary Arithmetic Performance in College Students?. College Student Journal; Sep2009, Vol. 43 Issue 3, p784786, 3p, 1 Chart.

68. Zubova, L. G, and Others.(2009), Graduating College Students' Orientations Toward Scientific Research Activity. Russian Education \& Society; Nov2009, Vol. 51 Issue 11, p61-70,10p. 